\title{
THE U.S. PROPOSAL FOR AN INTElleCtUAL PROPERTy CHAPTER IN THE TRANS-PACIfIC PARTNERShIP AGREEMENT*
}

\author{
SEAN M. FLYNN ${ }^{\dagger}$ \\ BROOK BAKER ${ }^{\ddagger}$ \\ MARGOT KAMINSKI ${ }^{\S}$ \\ JIMMY KOO
}

* We are thankful to the many contributors of analysis and comments on the TPP and reviewers of this paper, including Peter Maybarduk, Krista Cox, James Love, Gwen Hines, Caroline Rossini, Rashmi Rangath, Jane Kelsey, Sanya Smith, Hong Xui, Wendy Seltzer, David Levine, Peter Yu, Kim Weatherall, Peter Jaszi, Michael Carroll, Jonas Anderson, Jorge Contreras, Michael Palmedo, Jennifer Meuller, Lindsay Wiley, Fernanda Nicola, the participants in the American University Washington College of Law Junior Scholars Workshop, and the many negotiators of the Trans-Pacific Partnership Intellectual Property Chapter who have difficult jobs, work long hours in far away locations and who have been very generous with their time and have often striven to be as open and informative as they can be within the rules they work under. The errors we make are our own. A previous version of this paper was published as Public Interest Analysis of the US TPP Proposal for an IP Chapter, available at http://digitalcommons.wcl.american.edu/cgi/viewcontent.cgi?article=1023\&context= research.

${ }^{\dagger}$ American University Washington College of Law, Associate Director, PIJIP. Primary author of the article except as noted below.

$\ddagger$ Northeastern University School of Law, Program on Human Rights and the Global Economy. Primary author of Part III.

$\S$ Yale Law School, Executive Director, Information Society Project. Primary author of Part IV(H).

$\pi$ American University Washington College of Law, Fellow. Contributor to all sections. 


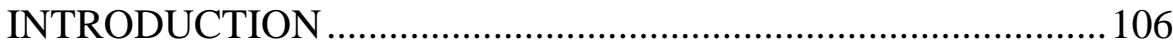

SECTION-BY-SECTION ANALYSIS ............................................121

I. GENERAL PROVISIONS: RELATION TO MULTILATERAL

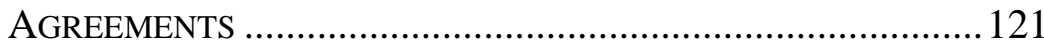

II. COPYRIGHT AND RELATED RIGHTS ..........................................124

A. Exclusive Reproduction Rights for Temporary

Electronic Copies............................................................125

B. Exhaustion of Rights and Parallel Importation ................130

C. Hierarchy of Rights...........................................................133

D. Copyright Term Extensions ...............................................134

E. Limitations and Exceptions and the Promotion of

"Balance" ..................................................................137

F. Technological Protection Measures ………………...........145

III. PATENTS AND DATA PROTECTION ………………………........ 150

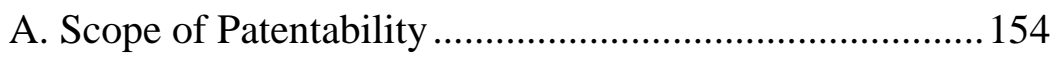

B. Exclusions from Patentability ...........................................158

C. Patent Term Extensions ……………………………..........160

D. Revocation and Oppositions .............................................163

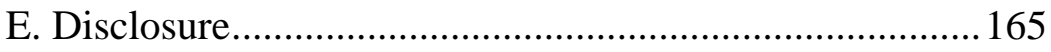

F. Industrial Applicability/Utility ..........................................166

G. Data Exclusivity................................................................167

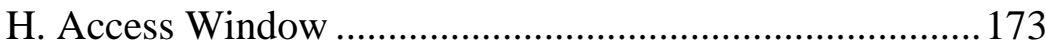

I. Patent/Registration Linkage ..............................................178

J. Doha Declaration on TRIPS and Public Health................181

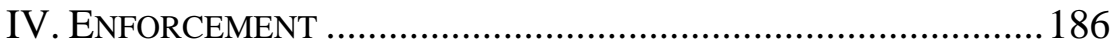

A. General Obligations .........................................................187

B. Injunctions and Border Suspensions ..................................188

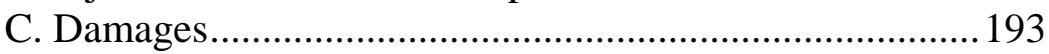

D. Criminal Offenses: “Commercial Scale”.........................196

E. Internet Service Provider Liability .....................................200

CONCLUSION ............................................................................203

\section{INTRODUCTION}

Over the last quarter century, the United States has aggressively shifted among various international law and policy-making forums to promote a goal of harmonizing the world's intellectual property laws 
in its image. ${ }^{1}$ In the 1980s and '90s, the primary forum for the achievement of that goal was multilateral ${ }^{2}$ - the United States was one of the primary promoters of the World Trade Organization accords of 1994, including its landmark agreement on Trade Related Aspects of Intellectual Property Rights ("TRIPS"). ${ }^{3}$ In the immediate post-TRIPS period, the multilateral regime became hostile to a U.S. agenda to further harmonize international intellectual property protection beyond TRIPS, ${ }^{4}$ and the agenda was confronted as well by

1. Cf. Trade Act of 2002, Pub. L. No. 107-210, § 2102, 116 Stat. 933, 995996 (codified at 19 U.S.C. § 3802) (setting as an international trade negotiating objective: "ensuring that the provisions of any multilateral or bilateral trade agreement governing intellectual property rights that is entered into by the United States reflect a standard of protection similar to that found in United States law").

2. Throughout this paper, we distinguish between what we call "multilateral," "plurilateral," and "regional" international law regimes. By "multilateral” we mean to designate those forums and agreements in which the construction of the norms is open to all countries that wish to participate, regardless of whether the ultimate agreement actually binds all countries of the world. Such agreements are most frequently negotiated within broad-based multilateral organizations headquartered in Geneva, such as the World Trade Organization or World Intellectual Property Organization. We thus refer to both the World Trade Organization agreements and the World Intellectual Property Organization Copyright Treaty as "multilateral," even though neither binds all countries. By using the term "plurilateral," we refer to those agreements, sometimes called "country club" agreements, in which an exclusive coalition of more than two countries negotiate the rules, which are then open to signatory by a broader group of countries. We use the term to describe agreements, including, e.g., the Anti-Counterfeiting Trade Agreement, in which geographic proximity is not a central factor limiting the membership in the drafting or joining coalition. We refer to "regional" agreements as those among more than two countries in a specific geographic region and in which the final agreement is not open to further membership expansion. The North American Free Trade Agreement is such an example. As described below, we refer to the Trans-Pacific Partnership as a plurilateral agreement because it has as a prime objective the expansion of membership beyond its original negotiating members and because, despite its potential limitation of membership to the Asia-Pacific Economic Cooperation region, both the negotiating members and the ultimate intended signatories are geographically diverse.

3. Agreement on Trade-Related Aspects of Intellectual Property Rights, Including Trade in Counterfeit Goods arts. 9.1, 21, Apr. 15, 1994, Marrakesh Agreement Establishing the World Trade Organization, Annex 1C, Legal Instruments-Results of the Uruguay Round, 1869 U.N.T.S. 299 [hereinafter TRIPS Agreement].

4. See Peter K. Yu, Currents and Crosscurrents in the International Intellectual Property Regime, 38 Loy. L.A. L. REV. 323, 326 (2004) (discussing developed countries' shift toward bilateral free trade agreements that position them 
growing public opposition from increasingly vocal and organized global social movements. ${ }^{5}$ A central argument of the opposition was that one size does not fit all in intellectual property policy and that, instead, countries need to take advantage of the flexibilities and ambiguities in the international legal system to craft laws to best serve their own policy goals. An over-expansion of one-size-fits-all intellectual property laws was framed as a threat to numerous vital social and economic objectives, including promoting access to affordable medications, enabling farmers to save and trade their own seeds, and ensuring that students can access affordable learning materials. ${ }^{6}$ In response to the success of this opposition at the multilateral level and in more open policy-making forums, the U.S. agenda shifted "vertically" into a series of closed-door bilateral and plurilateral trade agreement negotiations. ${ }^{7}$

"to use economic strengths to induce their less powerful trading partners to ratchet up intellectual property protection”); Peter Drahos, Expanding Intellectual Property's Empire: The Role of FTAs, InT'L CTR. FOR TRADE \& SUSTAINABLE DEV. 6-11 (2003), http://ictsd.org/downloads/2008/08/drahos-fta-2003-en.pdf (describing the post-TRIPS shift in U.S. strategies to bilateral and regional forums as a "process of forum shifting . . . from fora in which they are encountering difficulties" (WTO and WIPO) and as a process bent on achieving a "global ratchet for IP" through "waves of bilaterals . . . followed by occasional multilateral standard setting").

5. See Jean-Frédéric Morin, Multilaterlising TRIPs-Plus Agreements: Is the U.S. Strategy a Failure?, 12 J. WORLD INTELL. Prop. 175, 190 (2009) (describing the shift to bilateral trade agreements as an attempt to escape social movement attention). See generally Amy Kapczynski, The Access to Knowledge Mobilization and the New Politics of Intellectual Property, 117 YALE L.J. 804 (2008) (describing the rise and influence of social movements in the construction of international intellectual property law).

6. See Kapczynski, supra note 5 (describing the impact of social movement arguments on international intellectual property lawmaking).

7. See Susan K. Sell, TRIPS Was Never Enough: Vertical Forum Shifting, FTAs, ACTA and TPP, 18 J. InTELL. PROP. L. 447 (2011) [hereinafter Sell, TRIPS Was Never Enough] (describing a “multi-level” international intellectual property policymaking arena that has "expanded horizontally, across more multilateral institutions, and . . . vertically, from the multilateral level to the most granulareven down to individuals”); Laurence R. Helfer, Regime Shifting: The TRIPs Agreement and New Dynamics of International Intellectual Property Lawmaking, 29 YALE J. INT'L L. 1, 6-9 (2004) (describing bilateral agreements as part of "regime shifting" strategies of the United States and the European Union, both dissatisfied with the limitations of TRIPS); Drahos, supra note 4, at 7-9 (describing the "waves" and "cycle(s)" of bilateral and multilateral standard setting 
The first post-TRIPS forum shift by the United States was to bilateral agreements with a number of close allies and very small economies, beginning with the U.S.-Jordan Free Trade Agreement in 2001. In each of the agreements, a central dynamic in the negotiation was the offer of increased market access by the United States in exchange for the other country accepting "TRIPS-plus" commitments on domestic intellectual property regulation (i.e., minimum standards in excess of those required by the TRIPS Agreement). ${ }^{8}$ The bilateral agenda was largely successful in terms of escalating intellectual property standards among the U.S. partners in

phases that reinforce a general process of "ratcheting" of standards in the international IP system); Peter K. Yu, Six Secret (And Now Open) Fears of ACTA, 64 SMU L. REV. 975, 977-78, 988-98 (2011) [hereinafter Yu, Six Secret Fears] (describing the plurilateral Anti-Counterfeiting Trade Agreement as an effort by "like minded countries" to "consolidate the different protections that have already been developed through bilateral, plurilateral, and regional trade and investment agreements" in the face of opposition to norm setting on the same issues at WTO and WIPO).

8. See Pedro Roffe \& Christophe Spenneman, Intellectual Property Rights in Free Trade Agreements: Moving Beyond TRIPS Minimum Standards, in

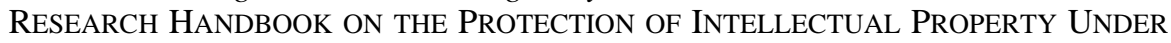
WTO Rules 266, 273 (Carlos M. Correa ed., 2010) (discussing the proliferation of “TRIPS-plus” intellectual property standards in free trade agreements, particularly between developing countries and the United States); Susan K. Sell, The Global IP Upward Ratchet, Anti-Counterfeiting and Piracy Enforcement Efforts: The State of Play, Am. Univ. Wash. Coll. L. Prog. Info. Justice \& Intell. Prop. (PIJIP Research Paper Series. No. 15, 2010), at 2-5, 15 [hereinafter Sell, Global IP Upward Ratchet], available at http://digitalcommons.wcl.american.edu/cgi/ viewcontent.cgi?article $=1016 \&$ context $=$ research (discussing the development of an "enforcement agenda" of higher standards of IP protection in U.S.-sponsored bilateral and plurilateral agreements promoted by organized corporate lobbying); Daniel Gervais, Of Clusters and Assumptions: Innovation as Part of a Full TRIPS Implementation, 77 Fordham L. Rev. 2353, 2359-60 (2009) (highlighting the recent trend of incorporating TRIPS-plus norms in bilateral and regional trade agreements signed by the United States and European Union); Morin, supra note 5, at 190 (2009) (describing the United States' use of bilateral agreements to create “a more stringent patent protection system"). This stage included a small number of multi-country regional agreements as well, including the Central American and Dominican Republic Free Trade Agreement (CAFTA-DR), and the failed Free Trade Agreement of the Americas (FTAA). Brook K. Baker, Ending Drug Registration Apartheid: Taming Data Exclusivity And Patent/Registration Linkage, 34 AM. J.L. \& MED. 303 (2008) (analyzing the efforts to obtain data monopolies through free trade agreements); Francisco Rossi, Free Trade Agreements and TRIPS-Plus Measures, 1 INT’L J. INTELL. PROP. MGMT. 150 (2006). 
a number of areas left open by TRIPS. But accounting for just $8.5 \%$ of all U.S. trade (most of which was in three of the eleven FTA partners), ${ }^{9}$ the bilateral commitments were not an end goal. Rather, the bilateral agenda was making way for a next stage that would "expand the stronger IPR commitments found in these bilateral agreements to a broader set of countries" through plurilateral agreements. $^{10}$

A plurilateral stage in post-TRIPS forum shifting by the United States began with the negotiation of the Anti-Counterfeiting Trade Agreement ("ACTA") between a set of geographically diverse, but like-minded (and largely high-income), countries and regions: the United States, Japan, Korea, the European Union, Switzerland, Australia, New Zealand, Mexico, Singapore, and Morocco. The goal was to establish a model that other countries could accede tocreating the base for an ultimately global agreement. The process used for the negotiation, insisted upon by the United States, was the closed and secretive model of a bilateral negotiation, rather than the more open and transparent process of the World Intellectual Property Organization ("WIPO") or, to a lesser extent, the World Trade Organization ("WTO”). ${ }^{11}$ The strategy appeared tailored to avoid an

9. The eleven post-WTO bilateral FTAs signed by the United States were with countries that together account for just $8.5 \%$ of overall trade with the United States-more than half of that occurring with just three of the FTA member states: Korea (2.7\%), Singapore (1.4\%), and Australia (1.0\%). Figures based on calculations by Jimmy H. Koo, based on data from U.S. CENSUS BUREAU, U.S. TRADE IN GOODS BY COUNTRY (2011), available at http://www.census.gov/ foreign-trade/balance/\#S.

10. Shayerah Ilias, Cong. Research Serv., R41107, The Proposed AntiCOUNTERFEITING TRADE AgREEMENT: BACKGROUND \& KEy Issues 6 (2010); see Yu, Six Secret Fears, supra note 7, at 1028-44.

11. See Yu, Six Secret Fears, supra note 7, at 998-1019 (describing the lack of transparency in and justifications for the ACTA process). For a comparison of transparency of international intellectual property lawmaking processes, see Jeremy Malcolm, Public Interest Representation in Global IP Policy Institutions, Am. Univ. WAsh. Coll. L. Prog. Info. Justice \& InTEll. Prop. (PIJIP Research Paper Series. No. 6, 2010), available at http://digitalcommons.wcl.american.edu/ cgi/viewcontent.cgi?article $=1006 \&$ context=research. WIPO recently expanded the transparency of some of its negotiations by webcasting them live for anyone to follow. See Michael Palmedo, Infojustice Roundup July 23, 2012, INFOJUSTICE.ORG (July 27, 2012, 9:46 AM), http://infojustice.org/archives/26756 (providing links to meeting documents and a live webcast of WIPO negotiations in 
open debate over the standards being proposed in the agreement. ${ }^{12}$ But the process ultimately backfired. A steady stream of leaks revealed proposals that alarmed public interest groups, academics, and many negotiating country legislatures. ${ }^{13}$ When the secretive agreement was completed and submitted to its first ratification process - in the EU Parliament-it was soundly rejected, ${ }^{14}$ stalling

the Standing Committee on Copyright and Related Rights).

12. Cf. Jean-Frederic Morin, Tripping up TRIPS Debates IP and Health in Bilateral Agreements, 1 InT’L J. InTELl. Prop. Mgmt. 37 (2006) (describing a shift to less transparent negotiating forums as part of effort by powerful actors to "institutionalize new unequal norms in other forums, not yet challenged by social movements"); Sean Flynn, ACTA's Constitutional Problem: The Treaty Is Not a Treaty, 26 AM. U. INT'L L. REv. 903 (2011) (describing the effort of the U.S. administration to push ACTA through as an executive agreement rather than through congressional ratification).

13. See, e.g., Sean Flynn, ACTA to Be Signed - But Can It Enter into Force?, INFOJUSTICE.ORG (Sept. 29, 2011, 11:06 AM), http://infojustice.org/archives/5699 (summarizing parliamentary controversies in Europe and Mexico); Text of Urgent ACTA Communique, Am. Univ. WAsh. Coll. L. Prog. Info. Justice \& Intell. Prop. (June 23, 2010), http://www.wcl.american.edu/pijip/go/acta-communique (concluding leaked ACTA text "is hostile to the public interest in at least seven critical areas of global public policy"); Over 75 Law Professors Call for Halt to ACTA, Am. Univ. Wash. Coll. L. Prog. Info. Justice \& InTell. Prop. (Oct. 28, 2010), http://www.wcl.american.edu/pijip/go/blog-post/academic-sign-on-letter-toobama-on-acta (criticizing the secretive process and concluding "ACTA would usurp congressional authority over intellectual property policy in a number of ways"); Opinion of European Academics on Anti-Counterfeiting Trade Agreement, 2 JIPITEC 65 (2011), available at http://www.jipitec.eu/issues/jipitec-2-12011/2965 (noting that ACTA would be contrary to EU policy and the public interest); Rashmi Rangnath, Shhhh. The TPP Is Secret, PUB. KNOWLEDGE (Feb. 21, 2012), http://www.publicknowledge.org/blog/shhhh-tpp-secret (discussing a civil society statement criticizing ACTA secrecy); Nate Anderson, Secret ACTA Treaty Can't Be Shown to Public, Just 42 Lawyers, ARs TeChNICA (Oct. 15, 2009, 10:39 AM), http://arstechnica.com/tech-policy/2009/10/these-42-people-are-shaping-usinternet-enforcement-policy/ (criticizing the lack of transparency during the ACTA negotiation process); Resolution on the Transparency and State of Play of the ACTA Negotiations, PARL. EUR. Doc. (SEC P7 TA (2010)0058) (Mar. 10, 2010) (stating that "deploring the calculated choice of the parties not to negotiate through well-established international bodies, such as WIPO and the WTO" and calling on the EU to release negotiating text and bring other developing countries into negotiation); Sean Flynn, Learning from ACTA: Toward a Positive Agenda for TPP, INFOJUSTICE.ORG (Mar. 3, 2012, 4:57 PM), http://infojustice.org/archives/ 8650 (summarizing social movement protests and parliamentary rejections of ACTA in Europe).

14. See Eric Pfanner, European Parliament Rejects Anti-piracy Treaty, N.Y. TiMES, July 4, 2012, at B5, available at http://www.nytimes.com/2012/ 
the ratification process elsewhere, perhaps permanently.

The fate of ACTA is uncertain, which has in turn called into question the viability of the plurilateral agenda's expansionist goals. If Europe could not be convinced to adopt the kind of TRIPS-plus (but often U.S.-minus) standards for intellectual property protection, how would the agenda ever reach those actively opposed to the U.S. agenda in multilateral forums, such as China, India, and Brazil?

There is one more ongoing forum in the U.S. plurilateral agendain the Trans-Pacific Partnership ("TPP”) negotiation, which the United States joined long before the demise of ACTA. The genesis of the TPP was the 2005 "P-4" trade agreement among four geographically diverse members of Asia-Pacific Economic Cooperation (“APEC”): Brunei, Chile, Singapore, and New Zealand. ${ }^{15}$ Like ACTA, the P-4 had an expansionist goal: to create a "high standards agreement that could serve as a model for a broader APEC-wide agreement, and to which other APEC members could accede." 16 The P-4 thus offered some of the main elements of a plurilateral forum that the United States was seeking in ACTA-a geographically diverse coalition of like-minded countries seeking a "high standards" agreement with a model for expansion. ${ }^{17}$ But there was one big omission from the U.S. perspective-the P-4 agreement

07/05/technology/european-parliament-rejects-anti-piracy-treaty.html?_r=0.

15. Meredith Kolsky Lewis, The Trans-Pacific Partnership: New Paradigm or Wolf in Sheep's Clothing?, 34 B.C. INT'L \& COMP. L. REV. 27, 29-35 (2011); IAN F. Fergusson \& Bruce Vaughn, Cong. Research Serv., R40502, The TransPacific Partnership Agreement, 1-4 (2010). The formal name of the P-4 agreement is the Trans-Pacific Strategic Economic Partnership Agreement, the text of which is available at http://www.mfat.govt.nz/downloads/trade-agreement/ transpacific/main-agreement.pdf.

16. Lewis, supra note 15 , at $32-33$. Specifically, the P-4 was meant to be a stepping stone toward a long-frustrated objective to create an APEC-wide Free Trade Agreement of the Asia-Pacific (FTAAP), covering $40 \%$ of the world's population and $50 \%$ of global gross domestic product. See Patrick Fazzone, The Trans-Pacific Partnership - Towards a Free Trade Agreement of Asia-Pacific?, 43 GEO. J. INT'L L. 695 (2012) (describing P-4 and TPP as steps toward larger APECwide strategy); Brock R. Williams, Cong. Research SerV., R42344, TransPACIFIC PARTNERSHIP (TPP) COUNTRIES: COMPARATIVE TRADE AND ECONOMIC ANALYSIS, 2 (2012) (summarizing economic research on trade benefits in the region).

17. See Lewis, supra note 15 , at 34 . 
has very little in the way of substantive TRIPS-plus commitments on intellectual property. ${ }^{18}$ Thus, when the United States announced in 2008 that it would seek to join and expand the P-4 agreement into a Trans-Pacific Partnership, ${ }^{19}$ one of its main objectives could be easily surmised - to insert into the agreement a new "high standard" intellectual property chapter modeled on ACTA and the recently

18. The intellectual property chapter of the P-4 agreement is just three and half pages long, compared to the nearly thirty pages that make up ACTA. Compare Trans-Pacific Strategic Economic Partnership Agreement ch. 10 [hereinafter P-4], available at http://mfat.govt.nz/downloads/trade-agreement/transpacific/mainagreement.pdf with Anti-Counterfeiting Trade Agreement, Oct. 5, 2011 [hereinafter ACTA], available at http://www.mofa.go.jp/policy/economy/ i_property/pdfs/acta1105_en.pdf. The scant provisions on intellectual property in the P-4 are largely devoted to reinforcing multilateral agreements and clarifying the application of limitations and exceptions to intellectual property rights, rather than the expansion of proprietor rights beyond the multilateral framework. See P-4, supra, art. 10.2(2) (recognizing the "need to achieve a balance between the rights of right holders and the legitimate interests of users and the community"); art. 10.3(2) (stating that "[n]othing in this Chapter shall prevent a Party from adopting appropriate measures to prevent the abuse of intellectual property rights" and "nothing in this Chapter shall prevent a Party from adopting measures necessary to prevent anti-competitive practices that may result from the abuse of intellectual property rights"); art. 10.3(3) (affirming that parties may "provide for the international exhaustion of intellectual property rights," "establish that provisions in standard form non-negotiated licenses for products do not prevent consumers from exercising the limitations and exceptions recognised in domestic intellectual property laws," "establish provisions to facilitate the exercise of permitted acts where technological measures have been applied," and "establish appropriate measures to protect traditional knowledge.”); art. 10.3(4) (“The Parties may establish limitations and exceptions in their domestic laws as acceptable under the Berne Convention for the Protection of Literary and Artistic Works (1971), the TRIPS Agreement, the WCT and the WPPT" and may "devise new exceptions and limitations that are appropriate in the digital environment"); art. 10.3(5) ("Subject to their obligations under the TRIPS Agreement, each Party may limit the rights of the performers and producers of phonograms and broadcasting entities of the other Party to the rights its persons are accorded within the jurisdiction of the other Party"). The one TRIPS-plus provision in the agreement reinforces the multilateral system rather than substituting for it. TRIPS requires members to "provide for reproduction rights and communication to the public rights to copyright owners and phonogram producers that are consistent with the World Intellectual Property Organization Copyright Treaty (WCT) and the World Intellectual Property Organization Performances and Phonograms Treaty (WPPT)"-two post-TRIPS agreements dealing with copyright in the digital environment and negotiated through WIPO. P-4, supra, art. 10.3(5).

19. Lewis, supra note 15 , at 34 . 


\section{concluded U.S.-Korea Free Trade Agreement. ${ }^{20}$ \\ Like ACTA, the TPP-since expanded to include Australia, Malaysia, Peru, Vietnam, and, most recently, Mexico and Canada,}

20. USTR officials said as much at many off-the-record briefings attended by the authors and others. Commentators often assumed the agenda from past practice. See Fergusson \& Vaughn, supra note 15, at 11-12 (surmising the United States would seek "contentious" TRIPS-plus intellectual property rules in negotiation). The U.S. desire to achieve an agreement that could be expanded to other countries was often explicit. See President Barack Obama, Remarks in Meeting with Trans-Pacific Partnership (Nov. 12, 2011) (noting that "[i]n a larger sense, the TPP has the potential to be a model not only for the Asia Pacific but for future trade agreements"); Ambassador Demetrios J. Marantis, Testimony Before the House Ways and Means Subcommittee on Trade on the Trans-Pacific Partnership (Dec. 13, 2011) (emphasizing that "we hope that advances made in the TPP agreement will serve as a model for future trade pacts"); Ambassador Demetrios J. Marantis, Remarks at the Washington Council on International Trade on the Obama Administration's Asia-Pacific Trade Policy (July 19, 2012) (stating that "[u]ltimately, our goal is to not just secure a high-standard agreement with our current TPP Partners, but to fulfill the vision of TPP as a platform for regional integration in the Asia-Pacific"); Letter from Members of Congress to Ambassador Ron Kirk, U.S. Trade Representative (June 27, 2012) (explaining that "[a]ccording to USTR statements, the TPP membership could ultimately include half of the nations of the world"); Office of the U.S. Trade Representative, In Pacific Pact, Obama Aims to Shape 21st Century Trade (Mar. 11, 2010), http://www.ustr.gov/ about-us/press-office/blog/2010/march/-pacific-pact-obama-aims-shape-21stcentury-trade (noting that " $[w]$ ith the TPP, the idea is to expand an agreement between New Zealand, Singapore, Brunei and Chile into a broader regional pact that advocates hope one day could also include China, Japan, South Korea, Taiwan and other major economies on both sides of the Asia Pacific"); Office of the U.S. Trade Representative, Outlines of the Trans-Pacific Partnership Agreement (Nov. 12, 2011), http://www.ustr.gov/about-us/press-office/fact-sheets/2011/november/ outlines-trans-pacific-partnership-agreement (highlighting "defining features that will make TPP a landmark, 21st-century trade agreement, setting a new standard for global trade . . .”); Office of the U.S. Trade Representative, Trans-Pacific Partnership Trade Ministers' Report to Leaders (Sept. 9, 2012) (commenting that "[w]e are pleased with our progress toward realizing each of the five defining features of this historic agreement, which we expect will set the standard for future trade agreements"); Ambassador Ron Kirk, Address in Singapore to the APEC CEO Summit (Nov. 13, 2009) (stating that "further engagement in the TransPacific Partnership gives us the opportunity to address gaps in our current agreements, and to set the standard for 21st-century trade agreements going forward"); Ambassador Ron Kirk, Address in Singapore Management University on U.S. Asia-Pacific Trade Policy (Apr. 26, 2012); Ambassador Ron Kirk, Remarks at the Washington International Trade Association (Dec. 15, 2009) (explaining that "we expect the TPP agreement to serve as a model for the future of American trade"). 
in addition to the original P-4 countries and the United States-is being negotiated under intense secrecy, including an agreement among the parties that no text of any proposal in the negotiation will be released until four years after the end of the negotiation. ${ }^{21}$ The use of such secretive forums for the making of international intellectual property law has been frequently criticized for being illsuited to taking into account the interests of the full range of stakeholders affected by such law.22 For international intellectual

21. See Trans-Pacific Partnership, Intellectual Property Rights Chapter (draft Feb. 10, 2011) [hereinafter TPP IP I], available at http://keionline.org/sites/ default/files/tpp-10feb2011-us-text-ipr-chapter.pdf (outlining, on the cover page of the leaked text, measures nations must take to keep the materials classified).

22. See Global Cong. On Intell. Prop. \& the Pub. Interest, Washington Declaration on Intellectual Property and the Public Interest, 2 (2011) [hereinafter Washington Declaration], available at http://infojustice.org/wp-content/uploads/ 2011/09/Washington-Declaration-Print.pdf (declaring that because "international intellectual property policy affects a broad range of interests within society, not just those of rights holders ... policy making should be conducted through mechanisms of transparency and openness that encourage broad public participation ... . [and] [n]ew rules should be made within the existing forums . . . [to ensure] both developed and developing countries have full representation, and ... the texts of and forums for considering proposals are open.”); Sean Flynn, Law Professors Call for Trans-Pacific Partnership (TPP) Transparency, INFOJUSTICE.ORG (May 9, 2012, 10:11 AM), http://infojustice.org/archives/21137 (maintaining that "if the goal [of the TPP process] is to create balanced law that stands the test of modern democratic theories and practices of public transparency, accountability and input," then public participation and transparency measures comparable to that afforded in lawmaking in multilateral institutions or Congress is needed in the TPP negotiating process); Press Release, U.S. Senator Sherrod Brown, With Trans-Pacific Partnership Negotiations Set to Continue in California Next Week, Senators Call for Increased Transparency, Including Broader Consultation on Internet Freedom (June 25, 2012), available at http://www.brown.senate.gov/newsroom/press/release/with-transpacific-partnership-negotiations-set-to-continue-in-california-next-week-senatorscall-for-increased-transparency-including-broader-consultation-on-internet-freedom (highlighting the statement by Senator Ron Wyden expressing astonishment at the secrecy under which American TPP negotiators operate). See generally Press Release, U.S. Congresswoman Rosa Delauro, DeLauro, Miller Push for More Transparency, Congressional Consultation in Trade Negotiations (June 27, 2012), available at http://delauro.house.gov/index.php?option=com_content\&view=article \&id=997:delauro-miller-push-for-more-transparency-congressional-consultation-intrade-negotiations\&catid=2:2012-press-releases\&Itemid=21 (demanding "broader and deeper consultations with members of the full range of committees of Congress" and releases of negotiating text to the public, arguing that the "goal of making any TPP FTA a high-level agreement that serves as a model for the world . . . requires transparency and sustained, ongoing consultations with the many impacted 
property scholars, the secrecy prevents analysis of the official proposals being considered in the negotiation. Partly for this reason, analysis of the TPP by such scholars has largely focused on its process rather than substance, including in studies of the more general trends in strategic forum shifting ${ }^{23}$ and in the turn to secrecy in international intellectual property lawmaking. ${ }^{24}$

This article takes advantage of the breach in the TPP's secrecy to contribute to a new and growing collection of published scholarship on leaked proposals for international intellectual property agreements as they are being negotiated. ${ }^{25}$ Leaked proposals in a confidential

congressional committees and the public").

23. See Sell, TRIPS Was Never Enough, supra note 7, at 448 (discussing TPP as an example of "vertical" forum shifting in international intellectual property lawmaking).

24. David S. Levine, Bring in the Nerds: Secrecy, National Security and the Creation of International Intellectual Property Law, 30 CARDOZO ARTS \& ENT. L.J. 105 (discussing TPP as an example of the turn to secrecy in recent negotiations of international intellectual property agreements, which "prevent the public ... from accessing information about the creation of international intellectual property law").

25. See generally Yu, Six Secret Fears, supra note 7, at 975 (tracing the development of ACTA using both leaked and final text and predicting the consequences); James Love, Leak of TPP Text on Copyright Limitations and Exceptions, KNowledge ECOLOGY INT'L (Aug. 3, 2012, 7:10 PM), http://keionline.org/node/1516 (highlighting and analyzing leaked text from the TPP); PIJIP Research Paper Series, AM. UnIV. WASH. Coll. Of LAW PROGRAM ON INFO. JUSTICE \& INTELl. PROP., http://digitalcommons.wcl.american.edu/ research/ (last visited Sept. 3, 2012) (containing a large collection of research papers on ACTA written by scholars from around the world throughout the secretive negotiation processes); KimBerleE G. WeAtherall, An Australian Analysis of the February 2011 Leaked US TPPA IP Chapter Text - Copyright and Enforcement, in SELECTED WORKS OF KIMBERLEE G. WeATHERALL 1 (2011), available at http://works.bepress.com/cgi/viewcontent.cgi?article=1022\&context= kimweatherall (compiling a table of provisions from leaked February 2011 proposals and noting that the proposal is a fusion of old agreements and ACTA); Margot E. Kaminski, An Overview and the Evolution of the Anti-Counterfeiting Trade Agreement, 21 ALB. L.J. SCI. \& TECH. 385, 386-88 (2011) (presenting an overview of ACTA's substantive provisions based on leaked text); Henning Grosse Ruse-Khan, From TRIPs to ACTA: Towards a New 'Gold Standard' in Criminal IP Enforcement?, Max Planck Institute fOR Intellectual PRoperty \& COMPETITION LAW, 7-11 (Max Planck Inst. for Intell. Prop. \& Competition Law Research Paper Series No. 10-06, 2010) [hereinafter Ruse-Khan, Gold Standard], available at http://papers.ssrn.com/sol3/papers.cfm?abstract_id=1592104\#\# (analyzing leaked ACTA provisions on criminal IP enforcement). 
international law negotiation are novel subjects for legal scholarship. But due to the formal secrecy of the negotiations, analysis of such text serves important public interests. These analyses contribute public commentary to aid policy makers and the public in understanding the potential import of lawmaking processes they cannot officially observe, ${ }^{26}$ and to provide an unofficial legislative history of the agreement for future legal interpreters and historians. ${ }^{27}$

We focus our analysis on the public interest effects of leaked U.S. proposals for an intellectual property chapter in the TPP (collectively, "TPP proposal”). ${ }^{28}$ We use the term "public interest” to

26. As is the case in other bilateral agreements, as well as with the AntiCounterfeiting Trade Agreement, the TPP proposal seeks to put in place a major and consequential shift in international standards for domestic intellectual property, Internet, and health regulation with scant public process, on the one side, and a highly structured and consultative relationship with a limited range of commercial interests on the other. See Rangnath, supra note 13 (describing and criticizing the use of a confidential "trade advisory committee" system in which select industry executives can see and contribute comments on confidential draft documents not made available to the general public). This process denies TPP negotiators access to a full range of views and analysis that deliberation in a public forum would attract. See Drahos, supra note 4, at 11 (describing "a networked private nodal governance that is formally woven into US policy and law-making at the highest levels"); Washington Declaration, supra note 22, at 2 (advocating increased oversight and review of new intellectual property standards). Somewhat ironically, the closed-door process being used in TPP violates the standards included in the leaked chapters on "Regulatory Coherence" and "Transparency and Procedural Fairness for Healthcare Technologies,” for example. See generally Leaked Trans-Pacific Free Trade Agreement Texts Reveal U.S. Undermining Access to Medicine, Citizens Trade CAMPAign (Oct. 22, 2011), http://www.citizenstrade.org/ctc/blog/2011/10/22/leaked-trans-pacific-fta-textsreveal-u-s-undermining-access-to-medicine/ [hereinafter Leaked Trans-Pacific Free Trade Agreement Texts Reveal Demands] (discussing how the leaked draft text of the regulatory coherence chapter attempts to "impose a structure and set of procedures for domestic decisions on all forms of regulation in current and prospective Trans-Pacific FTA countries" and noting that some portions of the chapter are "conducive to well-informed and consistent good decision making").

27. See Vienna Convention on the Law of Treaties art. 32, May 23, 1969, 1155 U.N.T.S. 331, 340 (identifying the preparatory works surrounding a treaty as a secondary source of interpretation). The extent to which the kind of informal legislative history contained in leaked texts can be part of the interpretive resources available to a future dispute resolution body is beyond the scope of this article.

28. See TPP IP I, supra note 21; Trans-Pacific Partnership-Intellectual Property Rights Chapter (Selected Provisions), Sept. 2011 [hereinafter TPP IP II], available at http://www.citizenstrade.org/ctc/wp-content/uploads/2011/10/ 
refer to the interests of the broad range of often diffuse and unorganized stakeholders, including consumers and users of intellectual property-protected information and products, who are affected by intellectual property laws but who do not have representatives formally included in the TPP lawmaking process. ${ }^{29}$

TransPacificIP1.pdf. A previously released version of this article included analysis of additional chapters of the leaked U.S. proposals, including proposals on trademark, geographical indicators, and pharmaceutical pricing. See Sean Flynn et al., Public Interest Analysis of the US TPP Proposal for an IP Chapter, Am. Univ. Wash. Coll. of Law Program on Info. Justice \& Intell. Prop. (PIJIP Research Paper Series No. 20, 2011), available at http://digitalcommons.wcl.american.edu/ research/21/).

29. This definition is in accord with that used in the legal profession more broadly. Public interest lawyers are those who represent the underrepresented. In this case, the underrepresented are the majority, as is the case in consumer rights advocacy more generally. See generally Comment, The New Public Interest Lawyers, 79 YALE L.J. 1069, 1069-71 n.3 (1970) (characterizing lawyers who represented social groups and interests that were underrepresented in the legal and political arenas, as "acting in the public interest"). We understand that some organizations representing consumers and other interests that we define as excluded from the formal process have been able to attend meetings with USTR negotiators, as well as with the negotiators with other countries, at TPP negotiating rounds, and elsewhere. This fact was raised by U.S. Trade Representative Ron Kirk in his description of the TPP as including "the most[] active outreach to all stakeholders relative to the TPP than in any FTA previously, including[] the proposed disciplines on intellectual property.” Sean Flynn, Kirk Responds to TPP Transparency Demands, INFOJUSTICE.ORG (May 10, 2012, 11:17 AM), http://infojustice.org/archives/21385. But this does not alter our conclusion that such groups are formally excluded from the process because, unlike the industry stakeholders, consumer groups are not granted access to the text of the proposals that the United States and other delegations are introducing in the lawmaking process. Through the Trade Advisory Committee system, a committee of fifteen industry representatives, chaired by a representative of the Pharmaceutical Research and Manufacturers of America, receives notice and an opportunity to comment on confidential drafts of all USTR text proposals on intellectual property before they are made in the formal negotiation. See U.S. Department of Commerce and the Office of the United States Trade Representative, Charter of the United States Trade Advisory Committee on Intellectual Property Rights, available at http://www.trade.gov/itac/committees/Charters/Intellectual_Property_Rights_ITA C.pdf (defining the criteria for membership in the committee as not more than fifty members from the private sector); Industry Trade Advisory Committee on Intellectual Property Rights ITAC 15, U.S. DEPARTMENT OF COMMERCE \& U.S. TRADE REPRESENTATIVE, http://ita.doc.gov/itac/committees/itac15.asp (last visited Sept. 6, 2012). Organizations representing consumer, health, library, small artist and other interests directly impacted by intellectual property law have no representation in the ITAC system and cannot officially view text of the proposals 
We provide this analysis out of a conviction that if the emerging agreement in the TPP is to include provisions that adequately balance the interests of intellectual property owners, on the one side, and users and the larger community, on the other, we believe that the interests of those excluded from the formal process must be amplified.

We begin with the general provisions of the agreement, which define its relationship to the multilateral system. We then progress to analysis of some of the most important copyright, patent and data protection, and enforcement sections of the proposal, before providing some concluding observations. Our ultimate conclusion is that the U.S. proposal, if adopted, would upset the current international framework balancing the interests of rights holders and the public. It would heighten standards of protection for rights holders well beyond that which the best available evidence or inclusive democratic processes support. ${ }^{30}$ It contains insufficient balancing provisions for users, consumers, and the public interest. ${ }^{31}$ The provisions would be particularly harmful for developing

until they are finished.

30. The TPP proposal includes many standards that far exceed agreements between some of the wealthiest countries of the world. See, e.g., Free Trade Agreement Between the United States and Republic of Korea, U.S.-Kor., June 30, 2007, http://www.ustr.gov/trade-agreements/free-trade-agreements/korus-fta/finaltext [hereinafter KORUS] (utilizing more modest standards to effectuate balance between users, consumers, and the public interest, contrary to leaked U.S. TPP proposal); ACTA, supra note 18 (purporting to address issues with international intellectual property rights "in a manner that balances the rights and interests of the relevant right holders, service providers, and users"). The dominant economic view is that such standards are not justified by any economic benefit to developing countries.

31. See Carsten Fink, Enforcing Intellectual Property Rights: an Economic Perspective, ICTSD PROGRAMme ON IPRs \& SuStainable DeV. (Intellectual Property and Sustainable Development Series, Issue Paper No. 22, 2008) at 7 , available at http://ictsd.org/downloads/2008/08/carsten-fink-enforcing-intellectualproperty-rights.pdf (noting that greater exclusive rights increase incentives to produce but also tend to increase the cost of goods beyond the cost of production, harming consumers); The Trans-Pacific Partnership Agreement: Your Guide to Copyright in the TPP, PUB. KNOWLEDGE, available at tppinfo.org (highlighting a number of U.S. proposals that would benefit rights owners but adversely affect consumers by, for example, giving rights owners copy protection and thereby exposing consumers to liability, or imposing far stricter criminal rules than U.S. criminal law). 
countries, where the risks and effects of exclusionary pricing by intellectual property monopolists are often most acute. ${ }^{32}$ The general thrust of the proposal conflicts with the "development agenda" being debated in WIPO, which has a much stronger focus on the harmonization of limitations and flexibilities in international intellectual property law. ${ }^{33}$ The proposal also conflicts with the overwhelming trend in multilateral institutions toward protection of TRIPS flexibilities for developing countries to promote access to affordable medications. ${ }^{34}$ The proposal would make these changes in the context of a new and powerful dispute resolution system that would greatly expand the standing, venue, and causes of action that could be used to challenge domestic policies, including through actions by corporations directly against states. ${ }^{35}$ This is, in short, an incredibly unbalanced proposal emanating from an extraordinarily imbalanced process.

32. See Sean Flynn et al., An Economic Argument for Open Access to Medicine Patents in Developing Countries, 37 J.L. MED. \& ETHICS 184, 189-90 (2009) (arguing that intellectual property monopolies on essential goods in developing countries with high income inequality predictably lead to pricing practices that are far more exclusionary than similar rights in wealthier countries with lower income inequality); Joe Karaganis ed., Media Piracy in EMerging Economies 61 (2011) [hereinafter MEDIA PIRACY IN EMERGING ECONOMIES] (finding patterns of exclusionary pricing of copyrighted media content in a selection of middle-income developing countries).

33. See World Intell. Prop. ORg. (WIPO), Dev. Agenda FOR WIPO (2007), available at http://www.wipo.int/freepublications/en/general/1015/wipo_pub_ 11015.pdf; see also Peter Yu, A Tale of Two Development Agendas, 35 OHIO N.U. L. REV. 465, 467 (2009) (comparing present and past intellectual property policy agendas led by developing countries).

34. See, e.g., UNDP HIV/AIDS GROUP, Global Commission on HIV and the Law: Rights, Risks, \& Health, 1, 86 (2012), http://www.hivlawcommission.org/ resources/report/FinalReport-Risks,Rights\&Health-EN.pdf ("High-income countries, including donors such as the United States . . . must immediately stop pressuring low- and middle-income countries to adopt or implement TRIPS-plus measures in trade agreements that impede access to life-saving treatment.”).

35. See TPP IP I, supra note 21, art. 4.9. 


\section{SECTION-BY-SECTION ANALYSIS}

\section{GENERAL PROVISIONS: RELATION TO MUltilaterAL AGREEMENTS}

The U.S. TPP proposal begins with an article on general provisions, including proposed commitments of each country to enter a long list of multilateral intellectual property agreements. ${ }^{36}$ A key question for negotiators will be whether the intellectual property chapter should be restricted to this kind of reinforcement of the multilateral system, as exists in the original P-4 agreement ${ }^{37}$ and has been common in other trade agreements and proposals for them. ${ }^{38}$ This is a particularly important question given the stated aim of the agreement to expand to all APEC countries, including countries such as China and Thailand, which may have very different ideas about intellectual property protection appropriate for their social and economic objectives. ${ }^{39}$

36. See id. art. 1 (requiring ratification of, in addition to other treaties, the Patent Cooperation Treaty (1970), the Berne Convention for the Protection of Literary and Artistic Works (1971), and the WIPO Copyright Treaty (1996)).

37. See P-4, supra note 18 (requiring countries to provide rights consistent with the post-TRIPS WIPO Copyright and Performances and Phonograms treaties).

38. See Roffe \& Spenneman, supra note 8, at 274-75 (describing the long policy of the EU, altered more recently, to limit IP commitments in its trade agreements to requirements to join certain multilateral IP treaties); see also Preliminary Considerations for TPP IP Chapter, General Provisions, CHILE TPP SUBMISSION [hereinafter CHILE TPP SUBMISSION], available at http://infojustice.org/download/tpp/tpp-texts/Chile\%20Proposal\%20for\%20

Intellectual\%20Property\%20Chapter,\%20February\%202011.pdf (last visited Sept. 7 , 2012) (calling for parties to provide for rights “consistent with" the WIPO Copyright and Performances and Phonograms treaties); Intellectual Property Chapter, NEw ZEALAND TPP SUBMISSION [hereinafter NEW ZEALAND TPP SUBMISSION], available at http://infojustice.org/download/tpp/tpp-texts/ New\%20Zealand\%20Proposal\%20for\%20Intellectual\%20Property\%20Chapter,\% 20February\%202011.pdf (committing members to support other members in joining the Patent Cooperation Treaty, Protocol Relating to the Madrid Agreement Concerning the International Registration of Marks, Singapore Treaty on the Law of Trademarks, and Nice Agreement Concerning the International Classification of Goods and Services for the Purposes of the Registration of Marks).

39. See Sean Flynn, Chilean Trade Officials Question \#TPP Benefits at Seminar in Santiago, INFOJUSTICE.ORG (Apr. 16, 2012, 12:01 PM), http://infojustice.org/archives/10712 (quoting Chilean politician Ricardo Lagos Weber, who expressed that a much greater benefit to the Latin American region 
Including substantive intellectual property provisions in the agreement itself poses threats to the coherence of the international intellectual property legal system. ${ }^{40}$ Standard dispute resolution clauses in U.S. free trade agreements ("FTAs") allow a complaining country to choose whether to bring a claim under the FTA's dispute resolution process or under the multilateral agreement when the same norm is included in both. ${ }^{41}$ However, the agreements do not set up a hierarchy of interpretations-meaning that the same clause in two agreements could be interpreted differently, with no possibility of rectifying diverging decisions. ${ }^{42}$ The United States is also proposing to introduce new mechanisms of enforcement that are not present in the multilateral system. These include “investor-state" dispute proceedings, where corporations can sue member states directly for alleged infringements, ${ }^{43}$ and "non-violation complaints," through

would be opening a trade market with China, but that the United States' proposed intellectual property chapter would make this eventuality nearly impossible).

40. See, e.g., Susy Frankel, WTO Application of "The Customary Rules of Interpretation of Public International Law" to Intellectual Property, 46 VA. J. INT'L L. 365, 402-03 (2006) (discussing how incorporating multiple treaties into TRIPS can raise complexities in interpretation).

41. See Roffe \& Spenneman, supra note 8, at 306.

42. This point was made with reference to the Berne Convention and the TPP. See Letter from James Love et al., Knowledge Ecology Int'l, to Barbara Weisel, Office of the U.S. Trade Representative (June 26, 2012), available at http://keionline.org/sites/default/files/TPP_Copyright_KEI2Weisel_26june2012.pd f ("We note that [the Berne Convention's] inclusion in a trade agreement such as the TPPA could result in multiple, differing interpretations on the meaning of its provisions. An existing and developing WTO jurisprudence exists on the Berne Convention which could come into conflict with the outcome of any dispute resolution under the TPPA.”). See generally Susy Frankel, WTO Application of "The Customary Rules of Interpretation of Public International Law" to Intellectual Property, 46 VA. J. INT'L L. 365, 402-03 (2006).

43. See Trans-Pacific Partnership, Leaked Investment Chapter Art. 12.2 (2011), available at http://www.citizenstrade.org/ctc/wp-content/uploads/2012/06/ tppinvestment.pdf (listing intellectual property as a definition of "investment" alongside others such as derivatives, debt securities, and bonds); see also Newly Leaked TPP Investment Chapter Contains Special Rights for Corporations, Citizens Trade CAMPAign (June 13, 2012, 8:00 AM), http://www.citizenstrade.org/ctc/blog/2012/06/13/newly-leaked-tpp-investmentchapter-contains-special-rights-for-corporations/ (providing context for the leaked proposal). The TRIPS Agreement, and the rest of the WTO accords, do not permit investors to sue states, but rather require that all complaints be brought by member states. See UNCTAD-ICTSD, Resource Book on TRIPS and Development: An 
which complaints not alleging violation of any specific clause of an agreement can be brought under a frustrated-expectations theory. ${ }^{44}$ Such provisions increase the "proliferation of international tribunals that subordinate the role of national legal systems in resolving disputes" 45 and increase the potential for international litigation challenging local policy decisions.

The TPP could use its opportunity to reinforce, rather than detract from, multilateral dispute resolution. The agreement could, for example, include a ban on unilateral adjudication of trade disputes, which remain prevalent in intellectual property matters through the U.S. "Special 301" program. ${ }^{46}$ Under Special 301, the United States uses an administrative adjudication to make unilateral findings on compliance of other countries with TRIPS and other agreements, resulting in listings on "watch lists" that many countries fear affect foreign investment. A WTO panel prohibited the use of similar

Authoritative and Practical Guide to the TRIPS Agreement 651 (2005) [hereinafter UNCTAD-ICTSD], available at http://www.ictsd.org/i/ip/11572/ (describing dispute settlement as arising only from complaints "by another Member").

44. See TRIPS Agreement, supra note 3, art. 64.2, Background and the current situation (describing non-violation complaints as existing "even when an agreement has not been violated" where a government alleges that "it has been deprived of an expected benefit because of another government's action, or because of any other situation that exists"). Such complaints are not currently permitted under TRIPS. See id., art. 64 (providing a moratorium on non-violation complaints). But arguably the WTO has been willing to entertain such complaints in any case. See Daniel Gervais, China-Measures Affecting the Protection and Enforcement of Intellectual Property Rights, 103 AM. J. INT'L L. 549, 549 (2009) (arguing that the WTO panel decision in the U.S.-China case "blurred both the traditional distinction between 'as such' and 'as applied' claims and the line separating TRIPS violations from non-violations”); Susy Frankel, Challenging TRIPS-Plus Agreements: The Potential Utility of Non-Violation Disputes, $12 \mathrm{~J}$. INT'L ECON. L. 1023, 1059 (2009) ("Given the lack of detail in the enforcement provisions the U.S. argument was really more of a non-violation complaint. The essence of what the U.S.A. was really complaining about was that a benefit it expected from the TRIPS Agreement was better levels of enforcement.”).

45. See B.S. Chimni, Third World Approaches to International Law: A Manifesto, 8 InT'L COMMUNITY L. REV. 3, 12 (2006).

46. See 19 U.S.C. § 2411 (2006); see also Sean Flynn, Special 301 of the Trade Act of 1974 and Global Access to Medicine, 7 J. GENERIC MED. 309, 310 (2010) [hereinafter Flynn, Special 301] (noting that the Special 301 program has restricted access to generic medicines in the least developed nations). 
threats and sanctions for general trade issues covered by the WTO. ${ }^{47}$ But the United States has continued to use Special 301 without ever invoking multilateral dispute resolution processes. ${ }^{48}$ Countries looking for a key concession from the United States within the intellectual property chapter could demand a halt of the use of such unilateral adjudication processes with respect to TPP member states.

\section{COPYRIGHT AND RELATED RIGHTS}

With the rapid technological evolution of the Internet into a primary means through which many communicate and engage in economic trade, the threat and promise of nearly free and ubiquitous digital copying of informational goods has brought the public interest effects of copyright into stark relief. Countries around the world are experimenting with different policies to strike the balance between the legitimate interests of artists and rights holders to be compensated for the use of their works, and the public interest in expanding access to information and media content in the digital era. U.S. law reflects an attempt to strike this balance, which is far from universally accepted. It mixes very strong proprietor rights and enforcement avenues, on the one side, with an open and robust set of user rights - including a flexible "fair use" right—on the other. The U.S. international agenda seeks to harmonize only the proprietor side of this equation. It insists on increasing the duration, scope, and

47. Panel Report, United States-Sections 301-310 of the Trade Act of 1974, 9 7.89, WT/DS152/R (Dec. 22, 1999) (noting that "Members faced with a threat of unilateral action, especially when it emanates from an economically powerful Member, may in effect be forced to give in to the demands imposed by the Member exerting the threat ... [and] merely carrying a big stick is, in many cases, as effective a means to having one's way as actually using the stick. The threat alone of conduct prohibited by the WTO would enable the Member concerned to exert undue leverage on other Members. It would disrupt the very stability and equilibrium which multilateral dispute resolution was meant to foster and consequently establish, namely equal protection of both large and small, powerful and less powerful Members through the consistent application of a set of rules and procedures").

48. The Special 301 program is an "informal agency adjudication" under the U.S. Administrative Procedures Act, Section 37. See Flynn, Special 301, supra note 46, at 312, 326 (explaining that the manner in which Special 301 has been utilized in the United States has had the effect of adjudicating other countries' compliance with WTO standards). 
enforcement of copyrights, especially on the Internet and through intermediaries, but it does so most frequently without any correlative expansions of limitations, exceptions, and user rights. The TPP proposal reflects this general and long-standing trend in U.S. postTRIPS FTAs, and as such would disadvantage the public interest in appropriately balanced copyright systems.

\section{A. Exclusive Reproduction Rights for Temporary Electronic Copies}

Art. 4.1. Each Party shall provide that authors, performers, and producers of phonograms have the right to authorize or prohibit all reproductions of their works, performances, and phonograms, in any manner or form, permanent or temporary (including temporary storage in electronic form). ${ }^{49}$

The extension of copyright protection to temporary electronic copies in the random access memory of computers and on the networks of telephone and Internet service providers has been a longstanding objective of the U.S. "digital agenda." ${ }^{50}$ The United States pushed the agenda during the negotiation of the 1996 WIPO Internet Treaties. ${ }^{51}$ During that negotiation, the United States supported proposed language extending the reproduction right in Article 9(1) of the Berne Convention to include "direct and indirect reproduction of their works, whether permanent or temporary, in any manner or form." 52 To stave off concerns that the provision would be radically overbroad, ${ }^{53}$ the proposal was linked to a specific authorization of limitation and exceptions for "transient or incidental" copies:

Subject to the provisions of Article 9(2) of the Berne Convention, it shall be a matter for legislation in Contracting Parties to limit the right of reproduction in cases where a temporary reproduction has the sole purpose of making the work perceptible or where the reproduction is of a transient or incidental nature, provided that such reproduction takes place in the course of use of the work that is authorized by the author or

49. TPP IP I, supra note 21 , art. 4.1, nn.8-10 (footnote numbers omitted).

50. Pamela Samuelson, The U.S. Digital Agenda at WIPO, 37 VA. J. INT'L L. 369, 378-84 (1997).

51. The term "WIPO Internet Treaties" is commonly used, and used herein, to collectively describe the 1996 WIPO Copyright Treaty (WCT) and WIPO Performances and Phonograms Treaty (WPPT).

52. Samuelson, U.S. Digital Agenda, supra note 50, at 384.

53. Id. at 385. 
permitted by law. ${ }^{54}$

Presented in an open forum subject to observation and participation by a broad range of stakeholders, the WIPO proposal generated significant opposition from consumers, libraries, and technology companies within the United States and abroad. Opponents argued, for example, that the clause would relieve "telephone companies or online service providers from potential liability for temporary copies of infringing material made in company equipment as the material passed through their systems en route from sender to recipient." 55 An Ad Hoc Alliance for a Digital Future, which later became the Digital Future Coalition, suggested a broader set of limitations, including:

where such reproductions (i) have the purpose of making perceptible an otherwise perceptible work; (ii) are of a transient or incidental nature; or (iii) facilitate transmission of a work and have no economic value independent from facilitating transmission; these being special cases where such reproduction does not conflict with a normal exploitation of the work and does not unreasonably prejudice the legitimate interests of the author. ${ }^{56}$

The coalition also advocated for a clause permitting additional limitations and exceptions to the temporary copy provision that otherwise complies with the three-step test in Berne Article 9(2). ${ }^{57}$

Considerable opposition emerged to the temporary copy provision at the diplomatic conference on the Internet Treaties, and ultimately the provision was dropped. ${ }^{58}$ The WIPO Performances and Phonograms Treaty ("WPPT") provides performers and producers of phonograms the exclusive right of authorizing the "direct or indirect reproductions" of work "fixed in phonograms, in any manner or form." 59 But it leaves countries free to define when a temporary

54. Id. at 384-85.

55. Id. at 385 (describing submissions by Netscape and other opponents of the proposal).

56. Id. at 386.

57. For further explanation of the three-step test, see infra Part II.E, discussing the limitations and exceptions provisions of the TPP proposal.

58. Samuelson, supra note 50, at 388-90.

59. WIPO Performances and Phonograms Treaty, S. Treaty Doc. No. 105-17, 36 ILM 76, art. 7 (1997) [hereinafter WPPT], available at http://www.wipo.int/ 
electronic copy will be considered sufficiently "fixed" so as to merit copyright protection. And an agreed statement on the application of the clause clarifies that parties may "carry forward and appropriately extend into the digital environment limitations and exceptions in their national laws which have been considered acceptable under the Berne Convention" and to "devise new exceptions and limitations that are appropriate in the digital network environment." ${ }^{\prime 0}$

The U.S. proposal for the TPP on temporary copies replicates the most controversial aspects of the Internet Treaties proposal, without any of the (imperfect) tempering language for limitations and exceptions that was linked to it. The proposal arrives at a time when there are multiple examples of legal standards, including in the United States, that appear far more attentive to needs for accommodating temporary copies in a digital world. In a provision of U.S. law not included in its TPP proposal, for example, copies are only considered adequately fixed so as to merit protection where they are "communicated for a period of more than transitory duration." ${ }^{\text {61 }}$ Fuller exceptions to the right of reproduction for temporary electronic copies that have "no independent economic significance,"62 "are necessary

export/sites/www/treaties/en/ip/wppt/pdf/trtdocs_wo034.pdf; id. art. 11 (incorporating the right of reproduction for producers of phonograms); Rome Convention, International Convention for the Protection of Performers, Producers of Phonograms and Broadcasting Organizations art. 4, Oct. 26, 1961, 19 ILM 1492 [hereinafter Rome Convention], available at http://www.wipo.int/export/ sites/www/treaties/en/ip/rome/pdf/trtdocs_wo024.pdf (conditioning protection requirements on the performance being "incorporated in a phonogram" or broadcast).

60. Agreed Statement to Article 10 of WIPO Copyright Treaty, available at http://www.wipo.int/treaties/en/ip/wct/statements.html; Agreed Statement to Article 16 of the WPPT, available at http://www.wipo.int/treaties/en/ip/wppt/ statements.html (providing that the agreed statement to WCT Article 10 applies mutatis mutandis to the WPPT).

61. 17 U.S.C. § 101 (2006) (defining “[c]opies” as "material objects, other than phonorecords, in which a work is fixed by any method now known or later developed, and from which the work can be perceived, reproduced, or otherwise communicated, either directly or with the aid of a machine or device ... [that] includes the material object, other than a phonorecord, in which the work is first fixed”); see Cartoon Network LP, LLP v. CSC Holdings, Inc., 536 F.3d 121, 129 (2d Cir. 2008) (concluding that buffer copies that remained in computer memory for a few seconds were too transitory to be entitled protection).

62. European Parliament \& Council Directive 2001/29/EC, art. 5.1, 2001 O.J. (L 167) 10, 16 (EC) (protecting "temporary acts of reproduction" with "no 
for the use of the computer program," 63 or are "required for the viewing, listening, or utilization of the said work" 64 have similarly become commonplace in recent copyright law reform. ${ }^{65}$ Notably, the agreed statement on flexibility in the digital environment from the WIPO Copyright Treaty ("WCT") was included in the Chile-U.S. FTA $^{66}$ but is not reproduced in the U.S. TPP proposal.

This is one of many provisions where the U.S. proposal reflects the extreme imbalance in influence in the U.S. policy-making process. There are large and influential interests in the United States, such as the Hollywood content industry, that would benefit from an extension of copyright protection to the electronic copies necessary for streaming and other content delivery services over the Internet. But other large and influential industries would have their business models threatened by such protection-including some of

independent economic significance").

63. European Parliament \& Council Directive 2009/24/EC. art. 5.1, 2009 O.J. (L 111) 16, 18 (EC) (providing that acts of reproduction of a computer program "shall not require authorisation by the rightholder where they are necessary for the use of the computer program by the lawful acquirer in accordance with its intended purpose, including for error correction").

64. Copyright (Amendment) Act of 2012 (Malay.) sec. 9(b), Act A1420 (adding exception for "the making of a transient and incidental electronic copy of a work made available on a network if the making of such copy is required for the viewing, listening, or utilization of the said work").

65. See also Copyright Act of 1987 (Rev. Jan. 31, 2006) (Sing.) sec. 38A, available at http://statutes.agc.gov.sg/aol/home.w3p (type "63" in the text box next to "Cap. or Act No." and click "Search"; then scroll to find section 38A in the left pane) (permitting temporary or transient reproductions made in the course of communication); Copyright Act 1968 (Austl.) sec. 43A, available at http://www.comlaw.gov.au/Details/C2012C00265/Html/Text\#_Toc317846224

(permitting temporary reproductions as part of making or receiving a communication or as a necessary part of using a work); Copyright Act 1994 (N.Z.) sec. 43A, available at http://www.legislation.govt.nz/act/public/1994/0143/latest/ whole.html (permitting transient or incidental reproductions).

66. Free Trade Agreement Between the United States and Chile art. 17.7(3) n.17, U.S.-Chile, June 6, 2003, http://www.ustr.gov/trade-agreements/free-tradeagreements/chile-fta/final-text [hereinafter Chile FTA] ("For works, other than computer software, and other subject matter, such exceptions and limitations may include temporary acts of reproduction which are transient or incidental and an integral and essential part of a technological process and whose sole purpose is to enable (a) a lawful transmission in a network between third parties by an intermediary; or (b) a lawful use of a work or other subject-matter to be made; and which have no independent economic significance.”). 
the fastest-growing Internet and technology companies in the world. When similar language was promoted in the open forum of WIPO, where every official proposal by a state is part of the contemporaneous public record, the concerns of those most acutely affected were raised, listened to, and ultimately validated through a defeat of the proposal. But those same interests are highly unrepresented in the FTA advising process. The Industry Advisory Committee that has the most influence over U.S. international intellectual property policy does not have a single representative of a streaming service of the kind most reliant on transitory copying for their business models. ${ }^{67}$

Chile's initial position in the TPP negotiation provides an alternative approach for promoting copyright standards in the digital environment that would avoid many of the pitfalls of the U.S. language. That proposal would require members of the TPP to implement the reproduction right of the WCT and the WPPT, with its built-in exceptions and clarifications in the agreed statements, and without the U.S. proposed extension of the right to temporary electronic copies ${ }^{68}$ The negotiators of the TPP should do no more on such a controversial issue in a secretive and unrepresentative process. The alternative course, currently being pressed by the Consumers and Communications Industry Association, is to fully express limitations and exceptions on the temporary right that are needed to support and enable digital commerce. ${ }^{69}$

67. Charter of the Industry Trade Advisory Committee on Intellectual Property Rights, U.S. DeP'T OF COMMERCE \& THE OfFICE OF THE U.S. TRADE ReP. (Feb. 19, 2010), http://www.trade.gov/itac/committees/ITAC15.IntellectualProperty Rights.asp.

68. See CHILE TPP SUBMisSion, supra note 38.

69. See Computer \& Communications Industry Associations, Internet Proposals for TPP, Copyright Exceptions, 1, 2 (2012), http://infojustice.org/ download/tpp/tpp-industry/CCIA-positive-proposal.pdf (proposing language for the TPP that "exceptions and limitations shall include temporary acts of reproduction which are transient or incidental and an integral and essential part of a technological process and whose sole purpose is to enable (a) a lawful transmission in a network between third parties by an intermediary; or (b) a lawful use of a work or other subjectmatter to be made; and which have no independent economic significance, in that the reproductions are of short duration or are not perceptible to the user"). 


\section{B. Exhaustion of Rights and Parallel Importation}

4.2. Each Party shall provide to authors, performers, and producers of phonograms the right to authorize or prohibit the importation into that Party's territory of copies of the work, performance, or phonogram made without authorization, or made outside that Party's territory with the authorization of the author, performer, or producer of the phonogram.

With respect to copies of works and phonograms that have been placed on the market by the relevant right holder, the obligations described in Article [4.2] apply only to books, journals, sheet music, sound recordings, computer programs, and audio and visual works (i.e., categories of products in which the value of the copyrighted material represents substantially all of the value of the product). Notwithstanding the foregoing, each Party may provide the protection described in Article [4.2] to a broader range of goods. ${ }^{70}$

TPP article 4.2 would create a new international legal requirement to provide copyright owners an exclusive right to block the parallel trade of broad categories of copyrighted works.

The U.S. proposal is directly contrary to the dominant multilateral rule in international intellectual property agreements protecting the ability of domestic law to determine when copyrights and other intellectual property rights "exhaust."71 By determining that a right is exhausted upon the first sale of the protected product by the right holder in any country (or in a specific region), countries can permit the "parallel importation" of protected products from other countries-that is, the importation of the protected product from another country where the same product is lawfully placed on the market by the right holder. ${ }^{72}$

70. TPP IP I, supra note 21, art. 4.2, n.11 (footnote number omitted).

71. See WIPO Copyright Treaty art. 6(2), Dec. 20, 1997, S. Treaty Doc. No. 105-17, 36 I.L.M. 65 (1997) ("Nothing in this Treaty shall affect the freedom of Contracting Parties to determine the conditions, if any, under which the exhaustion of the right in paragraph (1) applies after the first sale or other transfer of ownership of the original or a copy of the work with the authorization of the author.”); TRIPS Agreement, supra note 3, art. 6 (“[N]othing in this Agreement shall be used to address the issue of the exhaustion of intellectual property rights.").

72. Such trade is referred to as "parallel" because the goods sought to be accessed are protected by similar (aka "parallel") rights in each country. This distinguishes such trade from the importation of lawful, but unauthorized, copies 
Without an international exhaustion regime, rights owners can segment markets and determine their own prices and policies for entry into each market. Many countries are disadvantaged by such practices, particularly where they lack a sufficient consumer base to attract market entry at the lowest possible prices. In small markets like New Zealand and Australia, for example, and in many developing countries, copyrighted books and other works are often unavailable, or they are available only at higher prices than those found in larger markets. ${ }^{73}$ Consumers in the United States as well may benefit from parallel importation, such as in the case where the same textbooks are sold at lower prices abroad than they are at home. $^{74}$

There is no clear provision in the U.S. Copyright Act determining whether copyright owners can prevent the parallel importation of protected goods into the United States from other countries. The issue was presented to the Supreme Court in Costco Wholesale Corp. $v$. Omega, S.A., but the Court divided equally on the question, resulting in a decision with no precedential value. ${ }^{75}$ At the time of this writing, the Supreme Court has heard another case raising this

from another country, e.g., because the good is not protected in the second country.

73. See Weatherall, supra note 25, at 5 (explaining that "Australia's Productivity Commission has produced numerous reports in favour of more parallel importation of copyright works," to respond to "a history of experiencing higher prices for copyright works than markets such as the US and UK”). For discussions of pricing problems in developing countries, see generally Flynn et al., Economic Argument for Open Access, supra note 32 (discussing medicines); MEdia Piracy In EMERging ECONOMIES, supra note 32 (discussing media products); Alberto Cerda, USTR New Exclusive Right for Copyright Holders: Importation Provision in the Trans Pacific Partnership Agreement (TPPA), KNOWLEDGE ECOLOGY INT’L (July 5, 2011, 10:00 PM), http://keionline.org/ node/1176 (discussing parallel trade).

74. This is the fact pattern in the Kirtsaeng case before the Supreme Court, where a student imported books from Thailand to sell to U.S. students through EBay. See Adam Liptak, Justices Weigh Case on Imported Textbooks, N.Y. TIMES, Oct. 29, 2012, at B3, available at http://www.nytimes.com/2012/10/30/business/ supreme-court-hears-copyright-case-on-imported-textbooks.html?_r=0.

75. Omega S.A. v. Costco Wholesale Corp., 541 F.3d 982, 984-85 (9th Cir. 2008), aff'd per curiam 130 S. Ct. 2089 (2010) (applying the "first-sale" doctrine codified in Section 109(a) of the Copyright Act to prevent diverted sales of foreign-made products). 
interpretive question, but no decision has yet been issued. ${ }^{76}$ And whatever the outcome of that case, Congress would have the last word on the subject and could make clear the U.S. rule as it sees fit. Thus, this is an area where the U.S. negotiators are proposing harmonization of international law to a rule that does not exist in the United States-usurping domestic policy-making authority. ${ }^{77}$

Even if Congress refuses to change any U.S. statutes in response to the signing of the TPP, as is normally the case in FTA-implementing legislation, ${ }^{78}$ it could nevertheless have the practical effect of altering U.S. law. Under the so-called Charming Betsy principle, "an act of Congress ought never to be construed to violate the law of nations if any other possible construction remains, and consequently can never be construed... further than is warranted by the law of nations as understood in this country."79 Trade agreements, as part of our binding international obligations, can thus be used to interpret open questions in the United States. Furthermore, subsequent agreements can be used as lobbying tools, bolstering arguments that Congress must act in a certain way because its international obligations compel it to do so.

The best route to maintain the existing flexibility in U.S. law, as well as for the economic position of most countries in the TPP, would be to insist on safeguarding the multilateral rule that countries

76. See John Wiley \& Sons v. Kirtsaeng, 654 F.3d 210, 222 (2d Cir. 2011) (holding that the first-sale doctrine does not apply to copies manufactured outside of the United States).

77. See Letter from Professors Peter Jaszi, Michael Carroll, and Sean Flynn to USTR Ron Kirk on Limitations and Exceptions to Copyright in the TPP (Sept. 8, 2002), http://infojustice.org/archives/27183 [hereinafter Jaszi, Carroll, \& Flynn Letter] (citing parallel importation as well as proposed provisions prohibiting statutory licensing on television retransmission on the Internet as problematic examples where the USTR "describes its proposals and past FTA language as being 'consistent with,' and as 'coloring within the lines of,' U.S. law, even when its proposals constrain Congressional choices on matters that are currently the subject of discussion or concern").

78. See, e.g., United States-Korea Free Trade Agreement Implementation Act, Pub. L. No. 112-41, § 102, 125 Stat. 428 (2011) (noting that no application of the provision to discrete facts that are inconsistent with existing U.S. law shall have effect).

79. Murray v. Schooner Charming Betsy, 6 U.S. (2 Cranch) 64, 118 (1804) (noting that, not only national legislation, but also the law of nations should be considered in determining the legality of the capture of the Charming Betsy). 
remain free to establish their own exhaustion rules.

\section{Hierarchy of Rights}

4.4. In order to ensure that no hierarchy is established between rights of authors, on the one hand, and rights of performers and producers of phonograms, on the other hand, each Party shall provide that in cases where authorization is needed from both the author of a work embodied in a phonogram and a performer or producer owning rights in the phonogram, the need for the authorization of the author does not cease to exist because the authorization of the performer or producer is also required. Likewise, each Party shall provide that in cases where authorization is needed from both the author of a work embodied in a phonogram and a performer or producer owning rights in the phonogram, the need for the authorization of the performer or producer does not cease to exist because the authorization of the author is also required. ${ }^{80}$

The U.S. proposal to eliminate any "hierarchy" among copyright holders does not have an analogue in any multilateral agreement. Historically, there existed a hierarchy of rights in international intellectual property law. The first multilateral copyright treaty, the Berne convention, limited its protections to the literary and artistic work of authors. Later, the Rome Convention established some minimum standards for its members (which did not include the United States) on the rights of "related" entities, including performers and producers of phonograms. But the levels of protection were different from those for authors. ${ }^{81}$ The reason for all the differentiation was a perception in many countries "that works protected under related rights do not meet the same requirement of personal intellectual creativity as literary and artistic works." ${ }^{82}$

The U.S. hierarchy of rights proposal can be seen as a reflection of the growing trend in international law toward the harmonization of rights of authors with those of related or neighboring rights holders, reflected in the $1996 \mathrm{WPPT}^{83}$ and the recently signed, but not yet in

80. TPP IP I, supra note 21, art. 4.4.

81. See Rome Convention, supra note 59, art. 14 (allowing for twenty-year terms for related rights).

82. UNCTAD-ICTSD, supra note 43, at 199.

83. WPPT, supra note 59 (expanding international minimum standards on "related" and "neighboring" rights for performers and phonograms to fifty-year 
effect, Beijing Treaty on Performers' Rights in Audiovisual Productions. ${ }^{84}$ The rule that licenses are required of each rights holder for a protected use is the background rule in most, if not all, copyright legal systems. However, a prohibition of any hierarchy of rights, such that independent licensing is always required of each, may prohibit some beneficial policies. There a number of problems with the U.S. formulation of the three-step test and its inclusion in the TPP. A country may desire to speed licensing of some works by allowing one group of rights holders (e.g., the author) to license their rights while providing for compulsory licensing or other disposition of the rights of any remaining rights holders. Such a system could be necessary, for example, to allow music authors to participate in online auctions for music licensing, such as proposed by Ivan Reidel. ${ }^{85}$ Recognizing some hierarchy of rights with mandatory disposition of others may also be necessary to promote public access to the so-called "orphan works," where some rights holders are unknown or no longer exist. ${ }^{86}$

\section{Copyright Term Extensions}

Article 4.5 of the U.S. proposal for TPP would raise the minimum requirement for a copyright term from the current multilateral standard of 50 years after the author's death ${ }^{87}$ to the current U.S.

terms of protection, equal to that of authors).

84. See Press Release, WIPO, WIPO Beijing Treaty on Audiovisual Performances is Concluded (June 26, 2012), available at http://www.wipo.int/ pressroom/en/articles/2012/article_0013.html (reporting on the conclusion of the treaty to harmonize the international rights system for audiovisual performers with that of other related rights holders).

85. See Ivan Reidel, The Taylor Swift Paradox: Superstardom, Excessive Advertising and Blanket Licenses, 7 N.Y.U. J.L. \& Bus. 731, 805-08 (2011) (proposing an auction system in which recording artists could bid the royalties they would be willing to sell for radio play, thus allowing smaller artists to compete with more heavily resourced competitors on price).

86. See generally UNITED STATES COPYRIGHT OFFICE, REPORT ON ORPHAN WORKS 15 (Jan. 2006), available at http://www.copyright.gov/orphan/orphanreport-full.pdf (elaborating on the difficulties presented when trying to promote access to such "orphan works”).

87. See Berne Convention for the Protection of Literary and Artistic Works art. 7, Sept. 9, 1886, as revised at Paris on July 24, 1971, 1161 U.N.T.S. 30 and amended in 1979, S. Treaty Doc. No. 99-27 (1986) [hereinafter Berne Convention] (recognizing the term of protection as the life of the author plus fifty years); WIPO 
standard of 70 years from death of the author, 95 years from publication, or 120 years from the making of unpublished works. ${ }^{88}$ Length of copyright terms is an area of law where the U.S. model should not be considered an appropriate standard for the rest of the world.

The latest terms in the United States are the result of the controversial and much-criticized "Sonny Bono Copyright Term Extension Act" of 1998. As a coalition of law professors reported to Congress in opposition to that act at the time, the lengthening of copyright terms "impose[s] severe costs ... without providing any public benefit" while supplying "a windfall to the heirs and assignees of dead authors" and "depriv[ing] living authors of the ability to build on the cultural legacy of the past. ${ }^{89}$

Copyright Treaty, supra note 71, art. 1(4) (incorporating articles 1 through 21 of the Berne Convention); WPPT, supra note 59, art. 17 (indicating the term of protection for performers to be fifty years after the performance was first fixed in a phonogram).

88. TPP IP I, supra note 21, art. 4.5; see 17 U.S.C. § 302 (2006) (specifying the duration of copyright for works created on or after January 1, 1978). Although these requirements are generally consistent with the U.S. Copyright Act, it is noteworthy that the TPP proposal, like other FTAs, lacks some of the moderating principles contained in U.S. law, including presumptions of the death of authors and the definition of maximum, instead of minimum, terms. See Jodie Griffin, Inconsistencies Between the Trans-Pacific Partnership Agreement and US Law, PUB. KNOWLEDGE (2011), available at http://www.publicknowledge.org/files/ Jodie's\%20analysis.pdf (noting that, although TPP sets the specified terms as the minimum level of protection, U.S. law sets the term as a limit, and the TPP proposal fails to incorporate the presumption in 17 U.S.C. § 302(e) that after 95 years from first publication or 120 years after creation, an author's death is presumed).

89. Dennis K. Karjala et al., Statement of Copyright and Intellectual Property Law Professors on the Public Harm from Copyright Extension, OPPOSING COPYRIGHT EXTENSION (last visited Oct. 5, 2012), http://homepages.law.asu.edu/ $\sim$ dkarjala/opposingcopyrightextension/commentary/opedltr.html; see also J.H. Reichman, The Duration of Copyright and the Limits of Cultural Policy, 14 CARDOZO ARTS \& ENT. L.J. 625, 640 (1996) (decrying the alignment of terms of protection by noting that it might lead to unexpected results); Douglas Gomery, Research Report: The Economics of Term Extension for Motion Pictures, OpPOSING COPYRIGHT EXTENSION (Nov. 26, 1993), http://www.public.asu.edu/ $\sim$ dkarjala/commentary/gomery.html (suggesting that extending copyright protection for works for hire will not lead to greater distribution of works); Marci A. Hamilton, Copyright Duration Extension and the Dark Heart of Copyright, 14 CARDOZO ARTS \& ENT. L.J. 655, 657 (1996) (noting the lack of evidence on how 
The disproportionate costs associated with lengthening copyright terms in the other TPP member states are likely to be even higher than in the United States. Either because of the small size of their markets or high levels of poverty or income inequality in their consumer base, the non-U.S. members to TPP likely face higher barriers to accessing copyrighted works and are therefore more dependent on the public domain for accessing information and knowledge.

The negative impacts of the proposed copyright term extension are compounded by the U.S. proposal in Article 4.6 that they be applied back to existing works. ${ }^{90}$ As described above, the local economic benefit from lengthened copyright terms is minimal when applied to future works. With respect to existing works —-works already created under the then-applicable system-the economic benefit from longer terms is literally zero. You cannot incentivize the creation of a work that already exists. ${ }^{91}$ And thus copyright term extensions for existing

exactly copyright protection furthers public welfare); Dennis S. Karjala, The Term of Copyright, in Growing Pains: Adapting Copyright for Libraries, Education, and Society (Laura N. Gasaway ed., 1997), available at http://www.public.asu.edu/ $\sim$ dkarjala/commentary/term-of-protection.html; Cecil C. Kuhne, III, The Steadily Shrinking Public Domain: Inefficiencies of Existing Copyright Law in the Modern Technology Age, 50 LoY. L. REV. 549, 560 (2004) (contending that present copyright law inhibits the protection of works that do not have great value); EdWARD Rappaport, Cong. Research SerV., R98-144E, Copyright Term EXTENSION: ESTIMATING THE ECONOMIC VALUES 4 (May 11, 1998) (noting that adding twenty years to the current term of protection would be miniscule compared to the current incentive); Stephen Breyer, The Uneasy Case for Copyright: A Study of Copyright in Books, Photocopies, and Computer Programs, 84 HARV. L. REV. 281, 324 (1970) (opposing what became the 1976 extensions).

90. See TPP IP I, supra note 21, art. 4.6 ("Each Party shall apply Article 18 of the Berne Convention for the Protection of Literary and Artistic Works (1971) (Berne Convention) and Article 14.6 of the TRIPS Agreement, mutatis mutandis, to the subject matter, rights, and obligations in this Article and Articles [5] and [6].”); see also Berne Convention, supra note 87, art. 18 (“Convention shall apply to all works which, at the moment of its coming into force, have not yet fallen into the public domain in the country of origin through the expiry of the term of protection.").

91. See Dennis S. Karjala et al., Statement of Copyright and Intellectual Property Law Professors in Opposition to H.R. 604, H.R. 2589, and S. 505 "The Copyright Term Extension Act," OPPOSING COPYRIGHT EXTENSION 3-4 (Jan. 28, 1998), available at http://www.public.asu.edu/ dkarjala/legmats/1998 Statement.html ("Except in special cases, the economically efficient term of 
works only give a windfall to existing proprietors, with no correlative benefit to the public at large.

\section{E. Limitations and Exceptions and the Promotion of "Balance"}

1. With respect to this Article (Article 4 on copyright) and Article 5 and 6 (which deal with copyright and related rights section and the related rights section)], each Party shall confine limitations or exceptions to exclusive rights to certain special cases that do not conflict with a normal exploitation of the work, performance, or phonogram, and do not unreasonably prejudice the legitimate interests of the right holder.

2. Subject to and consistent with paragraph (1), each Party shall seek to achieve an appropriate balance in providing limitations or exceptions, including those for the digital environment, giving due consideration to legitimate purposes such as, but no [sic] limited to, criticism, comment, news reporting, teaching, scholarship and research.

For purposes of greater clarity, a use that has commercial aspects may in appropriate circumstances be considered to have a legitimate purpose under paragraph $2 .^{92}$

The U.S. proposal for a limitations and exceptions article in the TPP has two parts. The first part applies a controversial version of a "three-step test" to "confine" domestic flexibility in crafting limitations and exceptions. ${ }^{93}$ The second part requires countries to "seek to achieve balance" in copyright systems, which is being offered for the first time by the United States in any trade agreement. $^{94}$

The "three-step test" arises from the clause in Article 9.2 of the Berne Convention, added in 1967, which was meant to enable limitations and exceptions to the right of reproduction. That clause states:

"It shall be a matter for legislation in the countries of the Union to

intellectual property protection for works already in existence is zero, because by definition intellectual property is not depleted by use").

92. Leak of TPP Text on Copyright Limitations and Exceptions, KNOWLEDGE ECOLOGY INT'L (Aug. 3, 2012), http://keionline.org/node/1516.

93. Id.

94. Id. 
permit the reproduction of such works in certain special cases, provided that such reproduction does not conflict with a normal exploitation of the work and does not unreasonably prejudice the legitimate interests of the author." 95

Although the article has long been interpreted to include both a confining and enabling component, there was little real potential to use the test to restrict limitations and exceptions as a practical matter prior to the TRIPS Agreement; the Berne Convention was for all intents and purposes unenforceable. ${ }^{96}$ The inclusion of Berne Convention mandates in TRIPS, including a separate rephrasing of the three-step test, ${ }^{97}$ was a key element of a U.S. agenda to exert stronger disciplines on the ability of countries to craft broad limitations and exceptions to copyrights. ${ }^{98}$

In later iterations of the three-step test in the WPPT and WCT, the three-step test was crafted with separate enabling and confining clauses. Article 10(1) of the WCT, for example, provides that:

Contracting Parties may, in their national legislation, provide for limitations of or exceptions to the rights granted to authors of literary and artistic works under this Treaty in certain special cases that do not conflict with a normal exploitation of the work and do not unreasonably prejudice the legitimate interests of the author. ${ }^{99}$

\section{Article 10(2) introduces the confining formulation:}

Contracting Parties shall, when applying the Berne Convention, confine any limitations of or exceptions to rights provided for therein to certain

95. See P. Bernt Hugenholtz \& Ruth L. OKediJi, Conceiving AN INTERNATIONAL INSTRUMENT ON LIMITATIONS AND EXCEPTIONS TO COPYRIGHT 16-17 (2008), available at http://www.ivir.nl/publicaties/hugenholtz/ finalreport2008.pdf (discussing history and expansion to other instruments).

96. See Samuelson, supra note 50, at 404 (describing the GATT prohibition on retaliation with tariffs or other trade measures for violation of the Berne Convention prior to TRIPS and the use of TRIPS to add "teeth" to the Berne Convention mandates).

97. See TRIPS Agreement, supra note 3, art. 13 ("Members shall confine limitations or exceptions to exclusive rights to certain special cases which do not conflict with a normal exploitation of the work and do not unreasonably prejudice the legitimate interests of the right holder.").

98. Samuelson, supra note 50, at 398-409.

99. WIPO Copyright Treaty, supra note 71, art. 10(1). 
special cases that do not conflict with a normal exploitation of the work and do not unreasonably prejudice the legitimate interests of the author. ${ }^{100}$

In the U.S. FTA model, reflected in the TPP, there is only the confining language. ${ }^{101}$

There are a number of problems with the U.S. formulation of the three-step test and its inclusion in the TPP. First, unlike in the Berne Convention, but similar to Article 13 of TRIPS, the clause in the TPP proposal applies to all limitations and exceptions to rights, including categories of limitations and exceptions, such as the quotation right, that the Berne three-step convention exempts from its coverage. ${ }^{102}$ This raises the question of whether the clause is meant to further restrict domestic flexibility to implement other exceptions that are permitted or required under the Berne Convention. The United States claims no such intent. ${ }^{103}$ But it has conspicuously omitted the language of the agreed statement to the WCT that would make that more clear. ${ }^{104}$

100. Id., art. 10(2).

101. See, e.g., Chile FTA, supra note 66, art. 17.5.

102. See, e.g., Berne Convention, supra note 87, art. 10:

(1) It shall be permissible to make quotations from a work which has already been lawfully made available to the public, provided that their making is compatible with fair practice, and their extent does not exceed that justified by the purpose, including quotations from newspaper articles and periodicals in the form of press summaries.

(2) It shall be a matter for legislation in the countries of the Union, and for special agreements existing or to be concluded between them, to permit the utilization, to the extent justified by the purpose, of literary or artistic works by way of illustration in publications, broadcasts or sound or visual recordings for teaching, provided such utilization is compatible with fair practice.

(3) Where use is made of works in accordance with the preceding paragraphs of this Article, mention shall be made of the source, and of the name of the author, if it appears thereon.

See also Love, Leak of TPP Text on Copyright Limitations and Exceptions, supra note 25 (“Articles: 2(4,7), 2.bis, 10, 11, 11.bis(2-3), 13(1-2) and the Appendix are not subject to the 3-step test, and neither are the first sale doctrine (Article 6 of the TRIPS) or the control of anticompetitive practices in contracts (Article 40 of the TRIPS). Article 15(1) of the Rome Convention is also not subject to the three step test. Will the secret TPPA text change this?”).

103. See Jaszi, Carroll, \& Flynn Letter, supra note 77 (reporting from meetings with government officials that the United States does not intend to restrict further the so-called "small exceptions" under the Berne Convention that are not subject to the three-step test).

104. See Agreed Statement to Article 10 of WIPO Copyright Treaty, supra note 
Second, there is the important issue of interpretation of the clause. How are interpreters of the agreement to construe the conscious decision to include only the most restrictive, "shall confine," version of the three-step test, and not the more permissive enabling versions of that same test that appear in the post-TRIPS WIPO Internet Treaties? This issue may be particularly important in interpreting whether the clause is meant to include the clarifications of the threestep test in the agreed statements to Internet Treaties, especially those that permit parties to "carry forward" limitations and exceptions into the digital environment, and "devise new exceptions and limitations that are appropriate in the digital network environment." 105 Some of these problems could be lessened by including the Agreed Statement on Article 10 of the WCT in the TPP text, as was included in the U.S.-Chile FTA. ${ }^{106}$

Finally, there are problems with the three-step test as it has been interpreted by WTO panels. Recent WTO panels have required that the three-step test be applied in a "cumulative" fashion-such that the general balance of interests in the third "step" of the clause can only be considered after an analysis of whether the policy passes the first two "steps."107 Following from this formulaic and much criticized interpretation, ${ }^{108}$ some have raised questions as to whether

60 ("It is also understood that Article 10(2) neither reduces nor extends the scope of applicability of the limitations and exceptions permitted by the Berne Convention.”).

105. Id.

106. Chile FTA, supra note 66, art. 17.7(3) n.17.

107. See, e.g., Panel Report, United States - Section 110(5) of the US Copyright Act, ๆ 6.74, WT/DS160/R (June 15, 2000).

108. For academic criticism of the WTO's approach, see Graeme B. Dinwoodie \& Rochelle C. Dreyfuss, TRIPS and the Dynamics of Intellectual Property Lawmaking, 36 CASE W. RES. J. INT'L L. 95, 99-100 (2004) (contending that WTO's “discrete approach to adjudication . . . can produce perverse consequences”); Rochelle Cooper Dreyfuss, TRIPS-Round II: Should Users Strike Back?, 71 U. CHI. L. REV. 21, 22 (2004) (noting the problems arising from the "three-part” test bifurcated system, which "permits members to expand intellectual property rights, but makes them subject to challenge before the WTO when they reduce any of the incidents of protection”); Christophe Geiger, Exploring the Flexibilities of the TRIPS Agreement's Provisions on Limitations and Exceptions, in The Structure of Intellectual Property Law: Can One Size Fit All? 296-97 (Annette Kur \& Vytautas Mizaras eds., 2011) (predicting dangerous repercussions based upon how the WTO Panel interpreted the three-step test); 
the first step of the test-requiring that limitations and exceptions be limited to "certain special cases"-prohibits countries from adopting limitations and exceptions that, like U.S. fair use rights, turn on more abstract and flexible balancing criteria applied. ${ }^{109}$ The clause could

Daniel Gervais, Towards a New Core International Copyright Norm: The Reverse Three-Step Test, 9 MARQ. INTELl. Prop. L. Rev. 1, 27-29 (2004) (proposing a reversal of the "three-part" test, arguing that what the test does not allow is "what in fact copyright intended to protect”); Annette Kur, Of Oceans, Islands, and Inland Water - How Much Room for Exceptions and Limitations Under the ThreeStep Test?, 8 Rich. J. GloBAL L. \& Bus. 287, 311 (2009) (critiquing the length but lack of substance in the panel reports that have addressed the three-step test); Ruth Okediji, TRIPS Dispute Settlement and the Sources of (International) Copyright Law, 49 J. COPYRIGHT SOC’Y U.S. 585 (2001); MARTIN SENFTLEBEN, COPYRIGHT, Limitations AND THE Three STeP TEST 110 (P. Bernt Hugenholz ed., 2004) (downplaying the significance of the WTO's interpretation of the three-step tests as merely a supplemental means of interpretation); see also SOUTH CENTRE, THE TRIPS AGREEMENT: A GUIDE FOR THE SOUTH: THE URUguAY ROUND AgreEment on Trade-Related Intellectual Property Rights (1997), http://www.southcentre.org/index.php?option=com_content\&task=view\&id=87\& Itemid $=67$.

109. See WIPO, Comm. on Copyright \& Related Rights, WIPO Study on Limitations and Exceptions of Copyright and Related Rights in the Digital Environment, 9th sess., June 23-27, 2003, WIPO Doc. SCCR/9/7 (Apr. 5, 2003) (concluding that "it is unlikely that the indeterminate 'other purposes' that are covered by Section 107 meet the requirements of the first step of the three-step test, although it is always possible that, in any given case, they will find support under other provisions of Berne, such as Articles 10 and 10bis"); William Patry, Fair Use, the Three-Step Test, and the Counter-Reformation, PATRY COPYRIGHT BLOG (Apr. 2, 2008, 2:44 PM), http://williampatry.blogspot.com/2008/04/fair-usethree-step-test-and-european.html (responding to a "counter-reformation movement ... presently at the stage of a whispering campaign, in which ministries in countries are told that fair use (and by extension possible liberal fair dealing provisions) violate the 'three-step' test”); Martin Senftleben, Overprotection and Protection Overlaps in Intellectual Property Law - The Need for Horizontal Fair Use Defences, in The Structure of Intellectual Property Law: Can One SIZE FIT ALL?, supra note 108, at 133-45 (discussing certain special cases and rejecting the quantitative concept of the WTO). The lack of such flexibility is a problem in many countries with "closed-list" systems with specifically enumerated, and often very narrow, limitations. Many such closed lists lack exceptions clearly applicable to the digital age or evolving technology or practices. PIJIP and the Institute on Information Law (IVIR) in Amsterdam hosted a recent workshop where they reviewed the laws of fourteen countries from around the world and found that nearly every one of them, in the opinion of copyright scholars from their countries, lacked exceptions that comfortably addressed important modern digital activities, such as the making available of digital copies of library collections and creation and dissemination of user-generated content that 
be helpful in combating the formalistic "cumulative” interpretation of the three-step test by WTO panels if it adopted language following the Max Planck Institute's recommendation that the factors in the test "are to be considered together and as a whole in a comprehensive overall assessment." 110

The second part of the U.S. proposal-encouraging "balance" in copyright systems - is new to the U.S. FTA template. ${ }^{111}$ This "balance" proposal can be seen as a first response to the growing chorus of calls for increased attention to the need for international harmonization of mandatory minimum limitations and exceptions to intellectual property rights. The Washington Declaration on Intellectual Property and the Public Interest, for example, described limitations and exceptions as vital components of intellectual property doctrine, often serving the same innovation and creativityenhancing purposes as intellectual property protection itself:

Limitations and exceptions are positive enabling doctrines that function to ensure that intellectual property law fulfills its ultimate purpose of promoting essential aspects of the public interest. By limiting the private right, limitations and exceptions enable the public to engage in a wide range of socially beneficial uses of information otherwise covered by intellectual property rights — which in turn contribute directly to new innovation and economic development. Limitations and exceptions are woven into the fabric of intellectual property law not only as specific exceptional doctrines ("fair use" or "fair dealing," "specific exemptions," etc.), but also as structural restrictions on the scope of rights, such as

transforms copyrighted work into a new independent work not competing with the copyright holder. See Washington Declaration, supra note 22, at 3 (calling for "discussion of employing 'open-ended' limitations in national copyright legislation, in addition to specific exceptions”).

110. The Max Plank Institute, DECLARATION: A BALANCED INTERPRETATION OF THE “THREE-STEP TEST” IN COPYRIGHT LAW 4, http://www.ip.mpg.de/files/pdf2/ declaration_three_step_test_final_english1.pdf (last visited Sept. 7, 2012).

111. See Press Release, Office of the U.S. Trade Representative, USTR Introduces New Copyright Exceptions and Limitations Provision at San Diego TPP Talks (July 3, 2012), available at http://www.ustr.gov/about-is/press-office/ blog/2012/july/ustr-introduces-new-copyright-exceptions-limitations-provision (announcing that USTR was proposing, for "the first time in any U.S. trade agreement," a provision "that will obligate Parties to seek to achieve an appropriate balance in their copyright systems”). 
provisions for compulsory licensing of patents for needed medicines. ${ }^{112}$

To counter the growing trend of using international trade and other agreements to enact highly specific and enforceable proprietor rights standards, with little positive attention to commensurate limitations and exceptions, the Washington Declaration voiced broader calls in the academic and advocacy communities for "efforts to defend and expand as appropriate the operation of limitations and exceptions in the years to come," including through "the development of binding international agreements providing for mandatory minimum limitations and exceptions." 113

As a first step toward accepting the calls for more attention to mandatory limitations and exceptions in international intellectual property law, the U.S. proposal may have a number of positive impacts. It may help such interest communities advocate for appropriate limitations and exceptions as a necessary part of FTA implementation legislation. A similar clause may have been helpful in Colombia, for example, where a highly unbalanced implementation of the U.S.-Colombia FTA has led to a constitutional

112. Washington Declaration, supra note 22, at 3.

113. Id. For other calls for mandatory minimum limitations and exceptions, see Graeme B. Dinwoodie, Remarks: 'One Size Fits All': Consolidation and Difference in Intellectual Property Law, in THE STRUCTURE OF INTELLECTUAL PROPERTY LAW: CAN ONE SizE FIT ALL? supra note 108, at 13 (“[T]he substantive pressures created by minimum standards that are more real and less minimal need to be countered by ceilings that constrain in the other direction."); Senftleben, Overprotection and Protection Overlaps in Intellectual Property Law, supra note 109, at 136-37, 144 (arguing that the increased expansion of proprietor rights has created a need for flexible "fair use" rights in copyright and patent law); see also Dreyfuss, supra note 108, at 21-22 (2004) (advocating the use of explicit user rights); European Copyright Code, http://www.copyrightcode.eu/Wittem_ European_copyright_code_21\%20april\%202010.pdf (last visited Oct. 5, 2012) (including a draft code of mandatory minimum limitations and exceptions for Europe); HugenHOLTz \& OKEDIJI, supra note 95, at 3 (positing that limitations and exceptions are needed to "open up rapid advances in information and communication technologies that are fundamentally transforming the processes of production, dissemination and storage of information”); COMPUTER \& COMMC'NS INDUS. ASS'N., INTERNET INDUSTRY PROPOSALS FOR TPP, http://infojustice.org/ wp-content/uploads/2012/03/CCIA-positive-proposal.pdf (last visited Sept. 7, 2012) (proposing exceptions to copyright that would facilitate the "smooth functioning of the Internet”). 
challenge of the law. ${ }^{114}$ But the framing of the provision as a requirement only to "seek to achieve" balance, rather than actually provide such balance, dilutes the positive potential of the clause to blunt overly expansive framing of proprietor rights. The P-4 agreement recognizes a "need to achieve a balance between the rights of right holders and the legitimate interests of users and the community." 115 Neither balancing statement appears framed as an operative requirement that could be used in dispute resolution to challenge imbalances too far in the way of overly expansive proprietor rights.

The U.S. proposal may be helpful in countering the trend toward restrictive interpretations of the three-step test as applied to flexible limitations and exceptions. The U.S. proposal's encouragement of "balance," and explicit reference to elements of the balance in the U.S. fair use doctrine, may provide some evidence that flexible limitations and exceptions are not intended to be prohibited by the "special cases" prong of the three-step test.

The U.S. proposal may positively affect ongoing and future international negotiations. The provision signals openness of the United States to accepting expansions of mandatory limitations and exceptions in international intellectual property law-a key focus of the development agenda in the World Intellectual Property Organization. This shift in policy may aid the negotiations of binding treaties on limitations and exceptions for the blind, for libraries, and for educational institutions at WIPO, as well as supporting the inclusion of mandatory limitations and exceptions in other

114. See Mary Cecelia Bittner, Lawsuit Filed Against New FTA Copyright Laws, COLOMBIA REPORTS (Apr. 27, 2012, 8:19 AM), http://colombiareports.com/ colombia-news/news/23732-lawsuit-filed-against-new-fta-copyright-laws.html (discussing the constitutional challenge to Colombia's law implementing the FTA, noting the bill's stringent penalties and extended copyright protection); Letter from Peter Jaszi et al., Program on Info. Justice \& Intell. Prop., to Presidents of the Senate \& House of Representatives, Republic of Colombia (Apr. 9, 2012), available at http://infojustice.org/wp-content/uploads/2012/04/Colombia-Sign-OnLetter-with-Signatures-April-2012.pdf (criticizing Colombia for failing to "fully take into account the importance of balance in a healthy copyright system" in its implementation of the FTA).

115. P-4, supra note 18, art. 10.2(2). 
instruments. ${ }^{116}$

\section{F. Technological Protection Measures}

4.9. In order to provide adequate legal protection and effective legal remedies against the circumvention of effective technological measures that authors, performers and producers of phonograms use in connection with the exercise of their rights and that restrict unauthorized acts in respect of their works, performances, and phonograms, each Party shall provide that any person who:

(i) circumvents without authority any effective technological measure that controls access to a protected work, performance, phonogram, or other subject matter; or

(ii) manufactures, imports, distributes, offers to the public, provides, or otherwise traffics in devices, products, or components, or offers to the public or provides services, that:

(A) are promoted, advertised, or marketed by that person, or by another person acting in concert with that person and with that person's knowledge, for the purpose of circumvention of any effective technological measure,

(B) have only a limited commercially significant purpose or use other than to circumvent any effective technological measure, or

(C) are primarily designed, produced, or performed for the purpose of enabling or facilitating the circumvention of any effective technological measure,

shall be liable and subject to [criminal] remedies

(c) Each Party shall provide that a violation of a measure implementing this paragraph is a separate cause of action, independent of any infringement that might occur under the Party's law on copyright and

116. See Manon Res, Positive Agenda on Copyright, at the WIPO SCCR, KNOWLEDGE ECOLOGY INT'L (Aug. 27, 2011), http://keionline.org/node/1204 (speculating that the Standing Committee on Copyright and Related Rights (SCCR) may tackle the limitation and exceptions field of copyright and suggest new best practices). 
related rights.

(d) Each Party shall confine exceptions and limitations to measures implementing subparagraph (a) to the following activities, ${ }^{117}$

(viii) noninfringing uses of a work, performance, or phonogram in a particular class of works, performances, or phonograms when an actual or likely adverse impact on those noninfringing uses is demonstrated in a legislative or administrative proceeding by substantial evidence; provided that any limitation or exception adopted in reliance upon this clause shall have effect for a renewable period of not more than three years from the date of conclusion of such proceeding. ${ }^{118}$

The United States proposes that all TPP countries adopt nearly identical language on the circumvention of technological protection measures ("TPMs," or "digital locks"), as are found in the U.S. Digital Millennium Copyright Act ("DMCA"). As such, the clause represents a kind of double move in policy laundering through international agreements - through an international agreement to the U.S. Congress, and now back again into new international agreements.

The issue arises from the desires of the movie industry, first, and later the music and other industries, to be able to use encryption and other technologies to prevent the copying of digital media and other content. Because what can be encrypted can also be unencrypted, the industries pressed for new criminal law remedies against those who circumvent encryption technologies or who sell devices and software that enable such circumvention. ${ }^{119}$ Industries first took the issue to the

117. The provision lists specific activities in sections (i) through (vii), including reverse-engineering activities of a computer program "for the sole purpose of achieving interoperability"; activities by a researcher on flaws and vulnerabilities of technologies for scrambling and descrambling; preventing access of minors to inappropriate online content; testing, investigating, or correcting the security of that computer, computer system, or computer network; disabling a capability to carry out undisclosed collection or dissemination of personally identifying information; law enforcement, intelligence, essential security, and the like; and nonprofit library, archive, or educational institution for the sole purpose of making acquisition decisions.

118. TPP IP I, supra note 21, art. 4.9.

119. See Samuelson, supra note 50, at 410; see also Nicholas E. Sciorra, Self- 
U.S. Congress, which was unresponsive to early calls for new anticircumvention remedies. U.S. international negotiators nevertheless proposed such remedies in WIPO negotiations as an international standard that would bind the United States. Reflecting much of a proposal offered by U.S. negotiators, the Chairman's draft of the WIPO Copyright Treaty included a provision requiring that parties:

shall make unlawful the importation, manufacture or distribution of protection-defeating devices, or the offer or performance of any service having the same effect, by any person knowing or having reasonable grounds to know that the device or service will be used for, or in the course of, the exercise of rights provided under this Treaty that is not authorized by the right holder or the law. ${ }^{120}$

The draft differed from the U.S. proposal in including a "knowing" requirement-preventing strict liability as the U.S. proposed-and adding an express exception for circumvention authorized "by law," rather than only by the rights holder. ${ }^{121}$ One key objective of the WIPO draft was to ensure that countries would be free to implement the mandate in ways that would avoid impeding "lawful practices and the lawful use of subject matter that is in the public domain.”122 The final language, adopted in the WCT, was even more flexible, requiring only that members provide:

"adequate legal protection and effective legal remedies against the circumvention of effective technological measures that are used by authors in connection with the exercise of their rights under this Treaty or the Berne Convention and that restrict acts, in respect of their works, which are not authorized by the authors concerned or permitted by law."123

The WCT thus requires remedies for circumvention of digital locks only "in connection with the exercise of [authors'] rights," and only to prevent acts not "permitted by law." A country can implement this obligation with an exception for the circumvention of

Help and Contributory Infringement: The Law and Legal Thought Behind a Little "Black Box," 11 CARDOZO ARTS \& ENT. L.J. 905 (1993).

120. Samuelson, supra note 50, at 412 .

121. Id.

122. Id. at 413.

123. See WIPO Copyright Treaty, supra note 71, art. 11. 
locks for any purpose protected by limitations and exceptions to copyright. The WCT also does not require that the remedies provided be through criminal law. ${ }^{124}$

The U.S. proposal for the TPP imposes disciplines on domestic policy far in excess of those required by the WCT, and also in excess of the effort by ACTA to escalate the WCT standard. ACTA, like the original WCT proposal, would have required remedies only for a circumvention that occurs "knowingly or [with] reasonable grounds to know" that the action is illegal. ${ }^{125}$ ACTA would broadly permit parties to "adopt or maintain appropriate limitations or exceptions" to anti-circumvention liability, and was made "without prejudice to the rights, limitations, exceptions, or defences to copyright or related rights infringement under a Party's law." 126 None of these protections are replicated in the TPP proposal. Nor does the TPP include the proviso in ACTA that the minimum standards apply only to anticircumvention measures "to the extent provided by its law."

The U.S. proposal is not a pure reflection of U.S. law. For example, the proposal does not include the principle in U.S. judicial interpretations that there must be "a reasonable relationship between the circumvention at issue and a use relating to a property right for which the Copyright Act permits the copyright owner to withhold authorization."127 The TPP proposal is drafted to "confine” statutory

124. See UNCTAD-ICTSD, supra note 43 (explaining that "adequate legal protection" under WCT Article 11 "is to be determined by national legislation, according to national preferences" and therefore it is up to each country "to judge in which degree encryption technologies are justified, and to which extent cases of fair use should prevail").

125. See ACTA, supra note 18, art. 27.6(a)(i) (prohibiting "the unauthorized circumvention of an effective technological measure carried out knowingly or with reasonable grounds to know").

126. Id. art. 27.8. The U.S. proposal for a parallel discipline on punishing the alteration of rights management information is even more restrictive. The proposed TPP Article 4.10 provides for only one exception-for law enforcement purposes - to a requirement to criminalize the alteration of rights management information. TPP IP I, supra note 21, art. 4.10(a)-(b). ACTA, on the other hand, allows the protection of rights management information to be subject to the full scope of limitations and exceptions recognized under the parties' copyright laws. ACTA, supra note 18, art. 27.8.

127. Chamberlain Grp., Inc. v. Skylink Techs., Inc., 381 F.3d 1178, 1204 (Fed. Cir. 2004). But see MDY Indus., LLC v. Blizzard Entm’t, Inc., 629 F.3d 928, 950 
limitations and exceptions to a specific list of examples, with others permitted to be added only on a temporary basis through a regulatory process. ${ }^{128}$ Although the listed statutory exceptions are those from the DMCA, there is nothing in present U.S. law that would prohibit Congress from adopting new permanent statutory limitations and exceptions. The regulatory process described for recognizing new temporary limitations and exceptions is also more restrictive than in U.S. law. TPP Article 4.9(d)(viii), for example, requires that there be "substantial evidence" of an adverse effect on a protected activity to recognize an exception, ${ }^{129}$ whereas no such evidentiary threshold exists in current U.S. law. ${ }^{130}$

The U.S. proposal implicates numerous public interest concerns. ${ }^{131}$ The lack of a knowledge requirement would allow consumers to be held criminally liable for circumventing a TPM if they had no knowledge they were doing so, for example, when playing a regionally coded DVD on a multi-region player. ${ }^{132}$ The ban on the making and selling of circumvention tools could make it practically impossible for users to circumvent a TPM, even when they have every right to. ${ }^{133}$ The recognition of a separate cause of action for

(9th Cir. 2010) (holding that finding of circumvention under the DMCA does not require a nexus between circumvention and actual copyright infringement). See generally EFF Analysis of the TPM Provisions in the U.S. February 2011 Proposal for the TPP Intellectual Property Chapter, ElEc. FrontiER Found., https://www.eff.org/sites/default/files/filenode//EFF\%20TPP\%20TPM\%20Analysi s.pdf [hereinafter EFF Analysis] (last visited Sept. 7, 2012).

128. TPP IP I, supra note 21, art. 4.9(d).

129. See id. art. 4.9(d)(viii) (permitting exceptions for "noninfringing uses of a work, performance, or phonogram in a particular class of works, performances, or phonograms when an actual or likely adverse impact on those noninfringing uses is demonstrated in a legislative or administrative proceeding by substantial evidence; provided that any limitation or exception adopted in reliance upon this clause shall have effect for a renewable period of not more than three years from the date of conclusion of such proceeding").

130. See Griffin, supra note 88, at 4-5 (noting that the U.S. Library of Congress grants exemptions where there is "sufficient evidence" of a substantial adverse effect on non-infringing uses, but that "how much evidence is sufficient will vary" and "is never the only consideration in the rulemaking process").

131. See generally EFF Analysis, supra note 127 (summarizing experiences under the U.S. DMCA).

132. Id. at 9 .

133. See id. at 9-14 (noting that the U.S. DMCA provides certain exemptions that the TPM includes, such as permitting the use of copyrighted material for 
circumvention liability would restrict the range of materials in the public domain, permitting publishers to cut off access to material to which they have no right under copyright to exclude others from. ${ }^{134}$ And the extension of protection to objects that contain a copyrighted element, rather than for circumvention that itself commits copyright infringement, permits the standard to be used to limit the creation of interoperable consumer electronics - an anticompetitive effect not intended by copyright laws. ${ }^{135}$

\section{PATENTS AND DATA PROTECTION}

Some of the most controversial issues in the TPP intellectual property proposal are located in its patents and data protection provisions. This issue holds so much resonance in the international community that it led to the first and only TRIPS Council Declaration-The Doha Declaration on TRIPS and Public Healthand the first proposed amendment to the WTO Agreement. ${ }^{136}$ During the negotiation of the TRIPS Agreement, concerns about the potential impact of harmonized minimum standards on patents on access to medicines were a primary issue for many countries. As a

educational purposes and proposing that legislators and regulators set a burden-ofproof requirement for those seeking exemptions).

134. See id. at 11-15 (providing that these issues could be easily addressed by changing the scope of the provision to include language that is inclusive of circumvention and infringement).

135. See Chamberlain Grp., Inc. v. Skylink Techs., Inc., 381 F.3d 1178 (Fed. Cir. 2004) (action to prevent competitors from making interoperable garage openers); Lexmark Int'l, Inc. v. Static Control Components, Inc., 253 F. Supp. 2d 943 (E.D. Ky. 2003), vacated and remanded on other grounds 387 F.3d 522 (6th Cir. 2004) (use of anti-circumvention prohibitions to gain exclusive rights to printer cartridges); Storage Tech. Corp. v. Custom Hardware Eng'g \& Consulting, 421 F.3d 1307 (Fed. Cir. 2005) (action to protect computer maintenance software program); TracFone Wireless, Inc. v. SOL Wireless Grp., Inc., No. 05-23279-CIVAltonaga/Turnoff (S.D. Fla. Feb. 28, 2006), available at http://www.copyright.gov/1201/2006/posthearing/granick-e.pdf (action to prevent the provision of cell phone unlocking).

136. See General Council, Implementation of Paragraph 6 of the Doha Declaration on the TRIPS Agreement and Public Health, WT/L/540 and Corr. 1 (Sept. 1, 2003) (providing means for developing countries to import generic medicines); World Trade Organization, Declaration on the TRIPS Agreement and Public Health, WT/MIN(01)/DEC/2 (Nov. 20, 2001) (acknowledging the prevalence of public health epidemics that disproportionately affect developing countries, such as HIV/AIDS, tuberculosis, and malaria). 
result, the agreement was carefully crafted with numerous "flexibilities" that could be used in implementation to avoid an iron-clad one-size-fits-all patent policy for every WTO member. ${ }^{137}$ These include both the flexibility to domestically define and implement undefined terms, such as the criteria for "novelty" and "inventive step" needed to obtain a patent, as well as the enablement of specific limitations and exceptions to patent rights, such as the freedom to grant compulsory licenses. ${ }^{138}$

USTR's initial post-TRIPS efforts to use the Special 301 program and bilateral free trade agreements to escalate patent and other pharmaceutical-related standards in developing countries generated opposition within the United States, ${ }^{139}$ as well as from international

137. For objections to the idea that a "One-Size-Fits-All” standard is appropriate for all countries of the world, see Integrating Intellectual Property Rights and Development Policy, COMM'N ON INTELl. Prop. Rights, 155 (2002), http://www.iprcommission.org/papers/pdfs/final_report/CIPRfullfinal.pdf; Mattias Ganslandt et al., Developing and Distributing Essential Medicines to Poor Countries: The DEFEND Proposal, in INTELlECTUAL PROPERTY AND DEVELOPMENT: LESSONS FROM RECENT ECONOMIC RESEARCH 207, 215 (Carsten Fink \& Keith Maskus eds., 2005); Joseph E. Stiglitz, Intellectual-Property Rights and Wrongs, PROJECT SYNDICATE (Aug. 5, 2005), http://www.projectsyndicate.org/commentary/stiglitz61/English.

138. See generally Flynn, Special 301, supra note 46 (identifying a fuller catalogue of existing flexibilities); Sisule Musungu \& Cecilia Oh, The Use of Flexibilities in TRIPS by Developing Countries: Can They Promote Access to Medicines?, CIPIH STUDIES (Aug. 2005), http://www.who.int/intellectualproperty/ studies/TRIPS_flexibilities/en/index.html (same).

139. See, e.g., S. Res. 241, 110th Cong. (2007) (advocating that the United States should reaffirm its commitment to the Doha Declaration and engage in "trade policies that promote access to affordable medicines"); see also H.R. Res. 525, 110th Cong. (2007) (calling on the USTR to "honor” the Doha Declaration's affirmation of the rights "to use 'to the full' the flexibilities" in TRIPS and "not place countries on the 'Special 301' Priority Watch List . . . for exercising the flexibilities on public health provided for in the TRIPS Agreement”); MINORITY StAFF OF H. COMM. ON GOV'T REFORM, 109TH CONG., REP. ON TrAdE

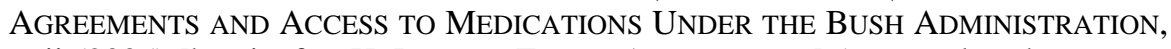
at ii (2005) [hereinafter H. REP. ON TRADE AGREEMENTS] (prepared at the request of Rep. Henry Waxman) (asserting that TRIPS-plus provisions on pharmaceuticals are "[c]ontrary to the principles of the Doha Declaration," because they "will significantly impede the ability of developing countries to obtain access to inexpensive, lifesaving medications”). For a discussion of civil society mobilizations around the issue of promoting and protecting access to affordable medicine in developing countries, see generally ELLEN F.M. 'T HOEN, THE Global Politics of Pharmaceutical Monopoly Power (2009); Susan K. Sell, 
agencies and organizations. ${ }^{140}$ The opposition led to notable changes in official U.S. policy. An executive order signed by President Clinton in 2000, which is still in effect today, bans the USTR and other parts of the U.S. government from seeking "through negotiation or otherwise, the revocation or revision" of any TRIPScompliant intellectual property law or policy of a beneficiary subSaharan African country that promotes "access to HIV/AIDS pharmaceuticals or medical technologies." ${ }^{141}$ The Kennedy Amendment to the 2002 Trade Promotion Authority legislation required trade policy to respect the Doha Declaration on TRIPS and Public Health. ${ }^{142}$ In May 2007, a bipartisan group of Congressional

TRIPS and the Access to Medicines Campaign, 20 WIS. INT'L L.J. 481 (2002).

140. See, e.g., Global Commission on HIV and the Law, supra note 34 (recommending a moratorium on inclusion of any new IP provisions in any international treaty that would limit countries' abilities to retain policy options for reducing the costs of AIDS medicines); Human Rights Council, Rep. of the Special Rapporteur on the Right of Everyone to the Enjoyment of the Highest Attainable Standard of Physical and Mental Health, Promotion and Protection of All Human Rights, Civil, Political, Economic, Social and Cultural Rights Including the Right to Development, ๆף 26-27, U.N. Doc. A/HRC/11/12 (Mar. 31, 2009) (by Anand Grover) (recommending how developing and less-developed countries may amend their own laws to incorporate TRIPS flexibilities); see also U.N. SecretaryGeneral, The Right of Everyone to the Enjoyment of the Highest Attainable Standard of Physical and Mental Health: Rep. of the Special Rapporteur, I 64, U.N. Doc. A/61/338 (Sept. 13, 2006) ("[N]o rich State should encourage a developing country to accept intellectual property standards that do not take into account the safeguards and flexibilities included under the TRIPS Agreement. In other words, developed States should not encourage a developing country to accept 'TRIPS-plus' standards.”); COMM’N ON INTELl. Prop. Rights, INNOVATION \& Pub. Health, Public Health: InNovation and Intellectual Property RIGHTS 145 (2006) ("Bilateral trade agreements should not seek to incorporate TRIPS-plus protection in ways that may reduce access to medicines in developing countries.”); World Health Org., Globalization, TRIPS and Access to Pharmaceuticals, 3 WHO Policy Perspectives on Meds. 5 (Mar. 2001) (" $[\mathrm{P}]$ oorer populations in developing countries should not be expected to pay the same price as do the wealthy for newer essential drugs. TRIPS-compliant mechanisms can be used to lower drug prices.”). See generally UNDP/UNAIDS, The Potential Impact of Free Trade Agreements on Public Health (2012) (explaining the constraints and flexibilities under the TRIPS Agreement).

141. Exec. Order No. 13,155, 65 Fed. Reg. 30,521 (May 12, 2000).

142. See Trade Promotion Authority and HIV/AIDS, CONSUMER PROJECT ON TECH., http://www.cptech.org/ip/health/trade/kennedy.html (last visited Sept. 5, 2012) (providing the arguments for the Kennedy amendment prior to the adoption of the Trade Promotion Agreement). 
leaders and the Bush Administration negotiated a "New Trade Policy for America," which limited the use of TRIPS-plus measures that impact access to medicines in pending agreements with developing countries. ${ }^{143}$ And, following the 2008 election campaign, thenPresident-elect Obama pledged to "break the stranglehold that a few big drug and insurance companies have on these life-saving drugs" and to support "the rights of sovereign nations to access qualityassured, low-cost generic medication to meet their pressing public health needs under the WTO's Declaration on Trade Related Aspects of Intellectual Property Rights (TRIPS)."144

The U.S. TPP proposal represents a substantial backtrack on these concerns, policies, and commitments. It attempts to harmonize substantive patent and data protection law in the TPP membership to U.S. standards on multiple controversial topics, including broadening scope of patentability, lengthening patent terms, imposing data exclusivity and patent/registration "linkage" requirements, and restraining numerous flexibilities in the TRIPS Agreement. These provisions would have predictable negative effects on the availability of affordable medicines in developing countries-a topic we focus on in these comments. But the repercussions will go further. Overly broad patent and data protection rights will raise the price of inputs into economies across a broad spectrum of industries. Additionally, they may "threaten the ability of innovators, especially in developing countries, to engage in research and development $(\mathrm{R} \& \mathrm{D})$ through reverse engineering and the creation of functional generic equivalents and improvements." ${ }^{145}$

143. See generally A New Trade Policy for America, H. Comm. ON WAYs \& MEANS, http://waysandmeans.house.gov/media/pdf/NewTradePolicy.pdf (last visited Sept. 7, 2012).

144. The Obama-Biden Plan to Combat Global HIV/AIDS, OfFICE OF THE PRESIDENT-ELECT, http://change.gov/pages/the_obama_biden_plan_to_combat_ global_hiv_aids/ (last visited Sept. 12, 2012).

145. Roffe \& Spenneman, supra note 8, at 279-80; see also Integrating Intellectual Property Rights and Development Policy, supra note 137, at 20-26, 111-36 (discussing impacts of patents on various social and economic policy concerns in addition to access to medicines). 


\section{A. Scope of Patentability}

8.1. Each Party shall make patents available for any invention, whether a product or process, in all fields of technology, provided that the invention is new, involves an inventive step, and is capable of industrial application. In addition, the Parties confirm that: patents shall be available for any new forms, uses, or methods of using a known product; and a new form, use, or method of using a known product may satisfy the criteria for patentability, even if such invention does not result in the enhancement of the known efficacy of that product. ${ }^{146}$

The U.S. TPP proposal would require the extension of patentability standards far beyond the definition of patentability contained in TRIPS Article 27.1. Although the U.S. proposal is inconsistent with the laws of other TPP negotiating countries, ${ }^{147}$ its prime target-India—is not part of the TPP negotiation. ${ }^{148}$ The TPP proposal is clearly drafted to counter the policy embodied in the 2005 Amended India Patents Act Section 3(d), ${ }^{149}$ which prohibits the

146. TPP IP I, supra note 21, art. 8.1 (footnote omitted).

147. The proposal would be contrary to the laws of Australia, Malaysia, and Vietnam. Burcu Kiliç \& Peter Maybarduk, Pub. Citizen, Dangers for ACCESS tO MEDiCINES in the TRANS-PACIFIC PARTNERShip AgREEMENT: COMPaRATIVE ANALYSIS OF THE U.S. INTELLECTUAL PROPERTY PROPOSAL AND Australian LaW 4 (2011) [hereinafter Kiliç \& MaybarduK, Australian LaW COMPARISON], available at http://www.citizen.org/Australia-TPPAChart\#! prettyPhoto (noting that Australia's patent act precludes patentability of a new use of a known substance that takes advantage of a known property); BURCU Kiliç \& Peter Maybarduk, Pub. Citizen, Dangers for AcCess to Medicines In the Trans-Pacific Free Trade AgreEment: Comparative Analysis of the U.S. INTELLECTUAL PROPERTY PROPOSAL AND MALAYSIAN LAW (2011), http://www.citizen.org/documents/Malaysia-chart.pdf [hereinafter KILIÇ \& MAYBARDUK, MALAYSIAN LAW COMPARISON] (noting that the current practice in Malaysia is to provide patent protection to first and second/subsequent uses of known products); VIETNAM AND THE TRANS-PACIFIC PARTNERSHIP AGREEMENT: Access to Medicines Risks for a PePFAR Partner, Pub. Citizen (2011), http://www.citizen.org/documents/Vietnam-and-the-Trans-Pacific-PartnershipAgreement.pdf [hereinafter Public Citizen TPP Vietnam Memo] (explaining that the U.S. proposal would "[lower] Vietnam's patentability standards and [require] patentability of new uses and minor variations of older, known drugs").

148. Risks of the TRANS-PACIFIC FREE TRADE AgREEMENT FOR ACCESS tO Medicines: ANALysis of the LeAKed U.S. PaPer on Eliminating Patent PreGrant OpPosition, Pub. Citizen 2 (2011) [hereinafter ANALYSIS OF U.S. PAPER].

149. Compare The Patents (Amendment) Act $\S 3(\mathrm{~d})$, No. 15 of 2005, INDIA CODE (2005) [hereinafter INDIA CODE], available at http://indiacode.nic.in, with 
granting of patents for "the mere discovery of a new form of a known substance which does not result in the enhancement of the known efficacy of that substance or the mere discovery of any new property or new use for a known substance or of the mere use of a known process, machine or apparatus unless such process results in a new product or employs at least one new reactant.”150

During the TRIPS negotiation, India was one of the leaders of a developing country coalition that actively resisted TRIPS, especially its requirement in Article 27 to grant patents on pharmaceutical products. When the initiation of negotiations over what was to become the TRIPS agreement began, there were around fifty countries that did not grant patents on pharmaceutical products. ${ }^{151}$ Accordingly, Article 27 of the TRIPS agreement, which stated that "patents shall be available for any inventions, whether products or processes, in all fields of technology provided that they are new, involve an inventive step and are capable of industrial application," ${ }^{152}$ required major changes in the laws of many countries and was one of the most controversial requirements of TRIPS. "Particular concerns have been expressed with regard to the availability and pricing of medicines after product patents are introduced in compliance with TRIPS," as well as that "strengthened exclusive rights will limit the scope for early legitimate imitation by local firms." 153

Article 8.1 would further expand patentability to require countries to permit patent applications on modifications or variations of new forms of existing chemical entities; new uses or methods of using existing

Ronald KirK, Office of the U.S. Trade Representative, 2012 Special 301 REPORT, 35 (2012) ("The United States continues to encourage India to promote a stable and predictable patent system that can nurture domestic innovation, including by resolving concerns with respect to the prohibition on patents for certain chemical forms absent a showing of increased efficacy.”).

150. INDIA CODE, supra note 149, § 3(d).

151. UNCTAD-ICTSD, supra note 43, at 353.

152. TRIPS Agreement, supra note 3, art. 27.1. TPP Article 8.1 also goes beyond the free trade agreement between the United States and Republic of Korea, which altered that TRIPS standard by adding "each Party confirms that patents shall be available for any uses or methods of using a known product." See KORUS, supra note 30, art. 18.8.1.

153. UNCTAD-ICTSD, supra note 43, at 364. 
medicines; ${ }^{154}$ and new formulations, dosages, and combinations. ${ }^{155}$ Countries would be required to do so even if there is no enhancement of therapeutic efficacy; indeed, efficacy could decrease and still receive protection. Each new patent on new forms, uses, or formulations of an existing medical product will result in a new twenty-year patent running from the date of patent application, thereby "evergreening" monopoly rights on the underlying medical product. ${ }^{156}$

India's Section 3(d) was explicitly crafted to take advantage of flexibilities in the interpretation of patent scope obligations that TRIPS left in place. TRIPS does not require either "use" or "form" patents. ${ }^{157}$ India's law was enacted to reduce evergreening of pharmaceutical patents and is widely recognized as a pro-public health and TRIPScompliant exception to patentability. ${ }^{158}$ Indeed, the World Bank has

154. See, e.g., Graciela Andrei et al., Topical Tenofovir, a Microbicide Effective Against HIV, Inhibits Herpes Simplex Virus-2 Replication, 10 CELL HOST \& MicroBe 379 (2011) (describing the use of HIV drug Topical Tenofovir to treat hepatitis for herpes simplex virus-2 prophylaxis).

155. See Carlos Correa, Pharmaceutical Innovation, Incremental Patenting and Compulsory Licensing, SOUTH CENTRE RESEARCH PAPER 41 (2011), http://www.southcentre.org/index.php?option=com_docman\&task=doc_download \& gid=2071\&Itemid=182\&lang=en.

156. See WIPO, PATENT LANDSCAPE REPORT ON RItONAVIR (2011), available at http://www.wipo.int/freepublications/en/patents/946/wipo_pub_946.pdf (discussing how, since the filing of the original patent application on Ritonavir, more than 800 families of evergreening patent applications have been filed, most in the United States). Those patent applications filed in 2009 will extend the exclusivity period from the original 2000 date to 2029 - twenty-nine extra years and counting. Note that some of the Ritonavir patents filed are process patents rather than product patents.

157. See UNCTAD-ICTSD, supra note 43, at 356-57 (describing the lack of TRIPS obligations on use patents); id. at 360 (describing options for developing countries to adopt high standards of inventiveness that would block U.S.-style patents on "minor or trivial developments").

158. See Carlos Correa, Guidelines for the Examination of Pharmaceutical Patents: Developing a Public Health Perspective 6-25 (WHO-ICTSD-UNCTAD, Working Paper, 2007), available at http://www.iprsonline.org/resources/docs/ Correa_Patentability\%20Guidelines.pdf (drawing on Section 3(d) and recommending that developing countries adopt comparable strict patentability standards, such as treating new formulations, compositions, salt patents, and enantiomers as obvious and/or as exceptions to patentability); How the TransPacific Partnership Agreement Threatens Access to Medicines, DocTORS WiTHOUT BORDERS (Sept. 2011), http://www.doctorswithoutborders.org/press/ 2011/MSF-TPP-Issue-Brief.pdf [hereinafter MSF TPP Issue Brief] (discussing the 
recommended provisions like India's, which suggests that developing countries "set high standards for the inventive step, thereby preventing routine discoveries from being patented.”159

India's Section 3(d) has been repeatedly challenged by the drug company Novartis, both in an unsuccessful constitutional and TRIPSbased challenge against Section 3(d) ${ }^{160}$ and in an appeal of a denial of a patent on the beta crystalline form of imatinibmesylate, the active ingredient in its cancer medicine Glivec. ${ }^{161}$ The U.S. proposal on new forms and new uses is best seen as the latest challenge to India's law in a new forum-here as part of a long-term campaign to implement new international standards that will ultimately be globalized to include India. But the strong opposition to the standard by countries like India suggests that inclusion of it in the final TPP agreement may be a major obstacle to TPP's expansion.

flexibility TRIPS affords governments to determine which innovations warrant patent protection, and noting how the U.S. proposal will significantly limit the ability of each individual country to exercise its discretion); SUDIP CHAUDHURI ET al., United Nations Dev. Programme, Five Years into the Product Patent REGIME: INDIA'S RESPONSE (2010), available at http://apps.who.int/ medicinedocs/documents/s17761en/s17761en.pdf. See generally Amy Kapczynski, Harmonization and Its Discontents: A Case Study of TRIPS Implementation in India's Pharmaceutical Sector, 97 CALIF. L. ReV. 1571 (2009) (examining how India's pharmaceutical industry has utilized TRIPS flexibilities); Janice M. Mueller, The Tiger Awakens: The Tumultuous Transformation of India's Patent System and the Rise of Indian Pharmaceutical Innovation, 68 U. PITT. L. REV. 491 (2007) (chronicling and analyzing India's implementation of pharmaceutical patents).

159. World Bank, Global Economic Prospects and the Developing COUNTRIES 143, (2001), http://siteresources.worldbank.org/INTGEP/Resources/ 335315-1257199011315/GEP2001_FullText.pdf.

160. See Novartis AG v. Union of India, W.P. No. 24759 of 2006 [2007] INTHC 2604 (6 August 2007), available at http://www.liiofindia.org/in/ cases/tn/INTNHC/2007/2604.html; see also Linda L. Lee, Trials and TRIPSulations: Indian Patent Law and Novartis AG v. Union of India, 23 BERKELEY TECH. L. J. 281, 312 (2008) (examining India's patent law changes for TRIPS compliance, the Novartis litigation, and Section 3(d)).

161. See Rachel Marusak Hermann, Novartis Before India's Supreme Court: What's Really at Stake?, InTELl. Prop. WATCh (Feb. 3, 2012, 12:05 PM), http://www.ip-watch.org/2012/03/02/novartis-before-india's-supreme-courtwhat's-really-at-stake (examining the possible consequences of Novartis's litigation with regard to India's public health clause of Section 3(d)). 


\section{B. Exclusions from Patentability}

8.2. Each Party shall make patents available for inventions for the following:

(a) plants and animals, and

(b) diagnostic, therapeutic, and surgical methods for the treatment of humans or animals. ${ }^{162}$

8.3. Each Party may only exclude from patentability inventions, the prevention within its territory of the commercial exploitation of which is necessary to protect ordre public or morality, including to protect human, animal, or plant life or health or to avoid serious prejudice to the environment, provided that such exclusion is not made merely because the exploitation is prohibited by law. ${ }^{163}$

Read together, proposed Articles 8.2 and 8.3 limit the discretion of domestic policies to provide for exceptions to patentability on one ground: where preventing the commercial exploitation of the invention "is necessary to protect ordre public or morality, including to protect human, animal, or plant life or health or to avoid serious prejudice to the environment." ${ }^{64}$ TPP Article 8.2 specifically requires parties to grant patents for plants, animals, and “diagnostic, therapeutic, and surgical methods for the treatment of humans or animals." 165 The application of patents to these areas, mirrored in KORUS Article 18.8.2, ${ }^{166}$ is expressly contrary to the right to exclude patents on such subject matter found in TRIPS Article 27.3. ${ }^{167}$ TPP Article 8.2 is also contrary to the actual practice of U.S. law, which allows patents on medical procedures but precludes use

162. TPP IP I, supra note 21, art. 8.2.

163. Id. art. 8.3.

164. Id. art. 8.2, 8.3.

165. Id. art. 8.2.

166. KORUS, supra note 30, art. 18.8.2 (preventing the exclusion of "diagnostic, therapeutic, and surgical procedures for the treatment of humans or animals”).

167. TRIPS Agreement, supra note 3, art. 27.3 (providing that " $[\mathrm{m}]$ embers may also exclude from patentability: (a) diagnostic, therapeutic and surgical methods for the treatment of humans or animals; (b) plants and animals other than microorganisms, and essentially biological processes for the production of plants or animals other than non-biological and microbiological processes” (emphasis added)). 
of such patents to seek remedies against medical practitioners. ${ }^{168}$

The proposal runs counter to the current law in several TPP member countries. ${ }^{169}$ It is also counter to a much broader trend to deem therapeutic, surgical, and diagnostic methods that affect human or animal bodies as "not patentable because of non-compliance with the industrial applicability requirement provided for in most patent laws, even in the absence of a specific exception.” ${ }^{{ }^{170}}$ TPP Article 8.2 would prohibit this common-sense application, in effect redefining the industrial applicability standard in its member countries.

The social and economic implications of treatment and relatedmethod patents could be pronounced. It could, for example, require licensing to practice a new treatment procedure domestically, thereby raising its local cost and producing scarcity of medical treatments. The provision could also be a back-door way to force recognition of "use" patents for pharmaceuticals, also proposed by the United States to be required in Article 8.1. ${ }^{171}$

The public ordre or morality exception, which mirrors TRIPS Article 27.2, is an exceptionally narrow one. Although some plant, animal, and treatment-method patents required by TPP Article 8.2 could potentially be excluded on "morality" grounds by virtue of 8.3 , exclusions under TPP Article 8.3 are subject to an important condition: patentability may only be denied if commercial exploitation of the invention is prohibited. "This excludes the

168. See 35 U.S.C. $§ 287$ (c) (2006) (providing that an infringement under this section is not enforceable against a practitioner or entity, and defining terms in accordance with the exemption).

169. See Kiliç \& Maybarduk, Australian LaW Comparison, supra note 147 , at 4 (noting that the proposed language would eliminate a flexibility recognized by Article 17.9.2 of AUSFTA); KILIÇ \& MAYBARDUK, MALAYSIAN LAW COMPARISON, supra note 147, at 3 (explaining that Section 13(1) of Malaysia's Patents Act of 291 of 1983 "expressly excludes treatment by surgery or therapy and diagnostic methods on the living human or animal body from patent protection”); Public Citizen TPP Vietnam Memo, supra note 147, at 3 (noting that the laws in "Vietnam and many other countries exclude diagnostic, therapeutic and surgical methods from patentability").

170. UNCTAD-ICTSD, supra note 43, at 384.

171. See id. at 387 ("In effect, there is no real difference between patent claims relating to the use of a substance and those relating to a therapeutic method: in both cases a new medical activity is claimed, i.e., a new way of using one or more known products.”) 
possibility of applying such exceptions when, for instance, it would be in the interest of public health to promote the diffusion of an invention (e.g., a medicinal product), since a Member cannot refuse a patent on ordre public or morality grounds and, at the same time, permit the commercialization of the invention." ${ }^{\prime 72}$ Thus, for example, a country could ban patents on animal clones if it also banned the sale of animal clones. But it could not use TPP Article 8.3 to justify an exclusion of surgical-method patents while allowing the surgical method to be practiced, nor could it ban patents on plant varieties or seeds while allowing such plants to be sold.

\section{Patent Term Extensions}

8.6. (a) Each Party shall make best efforts to process patent applications and marketing approval applications expeditiously with a view to avoiding unreasonable or unnecessary delays.

(b) Each Party, at the request of the patent owner, shall adjust the term of a patent to compensate for unreasonable delays that occur in the granting of the patent. For purposes of this subparagraph, an unreasonable delay at least shall include a delay in the issuance of the patent of more than four years from the date of filing of the application in the territory of the Party, or two years after a request for examination of the application has been made, whichever is later. Periods attributable to actions of the patent applicant need not be included in the determination of such delays.

(c) Each Party, at the request of the patent owner, shall make available an adjustment of the patent term of a patent which covers a new pharmaceutical product or a patent that covers a method of making or using a pharmaceutical product, to compensate that patent owner for unreasonable curtailment of the effective patent term as a result of the marketing approval process.

(d) In implementing subparagraph 6(c), a Party may:

(i) limit the applicability of subparagraph 6(c) to a single patent term adjustment for each new pharmaceutical product that is being reviewed for marketing approval;

(ii) require the basis for the adjustment to be the first marketing

172. Id. at 376 . 
approval granted to the new pharmaceutical product in that Party; and

(iii) limit the period of the adjustment to no more than 5 years. ${ }^{173}$

TPP Article 8.6 would require TPP member states to grant extensions of patent terms beyond the TRIPS twenty-year minimum patent term to compensate for delays both in patenting and in granting marketing approval. ${ }^{174}$ TRIPS Article 33 requires a patent term of twenty years. TRIPS does not require extensions beyond the twenty-year life of a patent for delays in granting a patent or marketing approval. The twenty-year standard was developed in recognition of the known delays encountered through the examination process.

Mandatory patent term extensions have been a highly controversial aspect of the post-TRIPS U.S. trade agenda on pharmaceutical policy. ${ }^{175}$ As part of the May 10, 2007, New Trade Deal, implemented in the U.S.-Peru FTA, patent term extensions for any reason were made optional rather than mandatory. ${ }^{176}$ The U.S.-

173. TPP IP II, supra note 28, art. 8.6.

174. The so-called "Access Window" features of TPP Article 8.6(e) are subject to TPP Article 9.2(b) or (d), which are discussed further below. See id., art. 9.2(e) ("In implementing subparagraph 6(c), and as a condition for providing the adjustment set forth in subparagraph 6(c) for a new pharmaceutical product approved consistent with Article 9.2(b) or Article 9.2(d), a Party may require an applicant that has submitted an application for marketing approval consistent with Article 9.2(b) or Article 9.2(d) to commence the process of obtaining marketing approval for that new pharmaceutical product in the Party within [6] years of the date of first marketing approval of the same pharmaceutical product in another Party."). The term "access window" was coined in the USTR press release describing the general outlines of the proposal to the public. See Press Release, Office of the U.S. Trade Representative, Trans-Pacific Partnership Trade Goals to Enhance Access to Medicines (Sept. 2011), available at http://www.ustr.gov/ about-us/press-office/press-releases/2011/september/trade-enhancing-accessmedicines.

175. See, e.g., H. ReP. ON TRAdE AgREEMENTS, supra note 139, at 8-9 (noting that the mandatory extensions do not take into account patent extension limitations in an individual country's laws, and thus may ultimately delay access to generic drugs).

176. See United States-Peru Trade Promotion Agreement Ch. 16, art. 16.9.6, U.S.-Peru, June 29, 2007, http://www.ustr.gov/webfm_send/1031; see also Bipartisan Agreement on Trade Policy, USTR (May 2007), http://www.ustr.gov/ sites/default/files/uploads/factsheets/2007/asset_upload_file945_11283.pdf (last 
Peru FTA allowed both countries to exempt pharmaceutical products from patent extension requirements. The U.S. TPP proposal would require patent extensions for unreasonable delays in product registration or issuance of a patent without the May 10 exemption, specifically removing the flexibility that Peru only recently received.

The TPP proposal also contains changes from previous FTA language on the topic. TPP Article 8.6 requires an increase in patent terms beyond twenty years to compensate for "unreasonable" delay in the granting of a patent, defined as a delay of more than four years from the date of filing of the application — the same as KORUS-or two years after a request for examination-one year shorter than KORUS. ${ }^{177}$ This requirement is broadly consistent with U.S. law, which has a three-year window. ${ }^{178}$ In addition, TPP Article 8.6 requires additional term extensions for regulatory delays in approving marketing of pharmaceutical products, including for patents that merely cover a new method of making or using a pharmaceutical product. As in other areas of TPP, although patent term extensions are mandatory, the limitation of patent term extensions - e.g., to a maximum of five years and no more than one extension (both attributes of current U.S. law ${ }^{179}$ ) - are permissive. ${ }^{180}$

The predictable impact of patent term extensions is to lengthen monopolies and, thereby, raise the medicines bill for member countries. Moreover, the time pressure of early patent examination and early marketing approval might result in over-extended patent offices granting invalid patents and in harried drug-regulatory

visited Aug. 5, 2012) (providing that U.S. Congressional leadership will implement “a more flexible approach" to patent extensions and include provisions requiring trading parties to "make best efforts to process patent and marketing applications expeditiously”).

177. KORUS, supra note 30, art. 18.8.6(a).

178. See 35 U.S.C. $\S 154(b)(1)(B)$ (2006) (explaining that, if the USPTO fails to issue a patent within three years from the actual U.S. filing date, it must extend the patent term one day for each day beyond the three-year period).

179. See 35 U.S.C. $\S 156$ (2006) (stating that the period of restoration extends from the original expiration date of the patent; however, the total patent term, with restoration, following FDA market approval may not exceed fourteen years).

180. TPP IP II, supra note 28, art. 8.6(d) (permitting regulatory-delay patent term extensions to be limited to a single adjustment for each new pharmaceutical product and for the basis of the adjustment to be the first marketing approval granted to a new pharmaceutical product). 
registering of unsafe or inefficacious medicines. This is especially a problem as the international volume of pharmaceutical patent applications and marketing approval applications grows, thereby overwhelming countries, especially developing countries, with weak regulatory capacity.

\section{Revocation and Oppositions}

8.7. Each Party shall provide that a patent may be revoked only on grounds that would have justified a refusal to grant the patent. A Party may also provide that fraud, misrepresentation or inequitable conduct may be the basis for revoking a patent or holding a patent unenforceable. Where a Party provides proceedings that permit a third party to oppose the grant of a patent, a Party shall not make such proceedings available before the grant of the patent. ${ }^{181}$

TPP Article 8.7 contains restrictions on the grounds for patent revocation and on processes for permitting pre-grant opposition of patent applications. The U.S. TPP proposal would require a change in Australia's law, which already includes a pre-grant opposition system. ${ }^{182}$ As in other areas of the TPP, the clearest target of the proposal may be India. Adopting this proposal would prevent the countries of the TPP from adopting the kind of pre-grant opposition processes that India has found useful. ${ }^{183}$

The U.S. proposal restricting the grounds for revocation represents an attempt to overturn a specific issue negotiated and rejected in the TRIPS negotiations. During the TRIPS negotiations, "attempts were made to limit revocation to cases where a patent had failed to meet the criteria for grant but this position did not find sufficient

181. TPP IP I, supra note 21, art. 8.7.

182. See Kiliç \& MAYBarduK, AUSTRALIAN LAW Comparison, supra note 147, at 2 (commenting that the TPP proposal would proscribe the "pre-grant opposition [process] in Australia [which] improves patent quality with minimal interference to well-drafted patent applications").

183. See Peter Drahos, The Jewel in the Crown: India's Patent Office and Patent-based Innovation, in InTELlectual Property REForm 80, 95 (Christopher Arup \& William van Caenegem eds., 2009) (noting 150 pre-grant oppositions filed by Indian generic industry since 2005); Shamnad Basheer, India's Tryst with TRIPS: The Patents (Amendment) Act, 2005, 1 INDIA. J. L. \& TECH. 15, 26 (2005) (describing how one may bring a pre-grant opposition claim under India's 1970 patent act). 
support."184 Thus, under TRIPS, members may authorize revocation of patents on a wide variety of grounds, including "on grounds of public interest.”185 Many countries, for example, authorize the revocation of patents for a failure to pay maintenance fees. ${ }^{186}$ Some countries (e.g., Andean Group, Costa Rica) allow for the revocation of patents based on a failure to disclose the origin of biological materials. ${ }^{187}$

There is no restriction on the grounds that may be used to revoke a patent under TRIPS. TRIPS Article 32 requires only that countries provide "[a]n opportunity for judicial review of any decision to revoke or forfeit a patent." This provision "only establishes a procedural requirement (the availability of judicial review), and does not stipulate the grounds or other substantive conditions for such acts to take place, thereby leaving considerable leeway to Members to legislate on the matter." 188 Likewise, under the earlier Paris Convention, revocation of a patent may be authorized to remedy any "abuse" of the patent, including for insufficient "working" of the patent, but only "in cases where the grant of compulsory licences would not have been sufficient to prevent the said abuses," and only after "expiration of two years from the grant of the first compulsory licence.”189

TPP Article 8.7 additionally bans the use of pre-grant oppositions. Pre-grant oppositions allow opportunities to contest a patent as it is filed, providing a potentially important source of information to patent examiners and generally improving patent quality. ${ }^{190}$ The United States has justified this restriction (in a

184. UNCTAD-ICTSD, supra note 43, at 423.

185. Id.

186. Id.

187. Id. at 423 n.773.

188. Id. at 414.

189. Paris Convention for the Protection of Industrial Property art. 5(A)(3), as last revised at Lisbon, Oct. 31, 1958, 21 U.S.T. 1583, 828 U.N.T.S. 305.

190. Dietmar Harhoff et al., Citations, Family Size, Opposition and the Value of Patent Rights, 32 ReSEARCH Policy 1343, 1358-59 (2003); see also Tahir Amin et al., Expert Review of Drug Patent Applications: Improving Health in the Developing World, 28 HEALTH AFFAIRS 948, 951-52 (2009), available at http://content.healthaffairs.org/content/28/5/w948.full.pdf+html (arguing that pregrant opposition systems lead to efficiency gains without causing problems of 
leaked memorandum) as being in the interest of patent offices. ${ }^{191}$ But the proposal, especially when viewed in conjunction with the U.S. proposal to require countries to permit unlimited amendments to patent applications, ${ }^{192}$ will be directly counter to the interests of most patents offices. The interests of many patent offices will be best served by maximizing pre-grant oppositions and minimizing opportunities to amend patent claims after they are filed. In such a system, companies have incentives to file only their strongest claims, leading to a lower volume of weak applications and stronger overall patent value. ${ }^{193}$

\section{E. Disclosure}

8.10. Each Party shall provide that a disclosure of a claimed invention shall be considered to be sufficiently clear and complete if it provides information that allows the invention to be made and used by a person skilled in the art, without undue experimentation, as of the filing date. ${ }^{194}$

8.11. Each Party shall provide that a claimed invention is sufficiently supported by its disclosure if the disclosure reasonably conveys to a

abuse of the system or rising costs of delay).

191. See Pre-Grant Opposition, PUB. CITIZEN, http://www.citizen.org/ documents/Leaked-US-TPPA-paper-on-eliminating-pre-grant-opposition.pdf (last visited Sept. 7, 2012) ("A lengthy or onerous pre-grant patent opposition system can place undue burdens on patent applicants and create additional costs to patent offices, thereby causing uncertainty and deterring innovators and enterprises that would otherwise bring innovative products and services to TPP partners.”).

192. TPP IP I, supra note 21, art. 8.9 ("Each Party shall provide patent applicants with at least one opportunity to make amendments, corrections, and observations in connection with their applications. Each Party shall permit applicants to make amendments to their patent claims prior to receipt of a first patent office action or communication on the merits.”).

193. See, e.g., Harhoff et al., supra note 190, at 1358 (finding that patents that are upheld in opposition procedures are particularly valuable); ANALYSIS OF U.S. PAPER, supra note 148; see also K.M. Gopakumar \& Sanya R. Smith, IPR Provisions in FTAs: Implications for Access to Medicines, in WHO, INTELLECTUAL PROPERTY AND ACCESS to Medicines: PAPERS AND PERSPECTIVES 141, 144 (2010) (criticizing the elimination of pre-grant opposition in U.S. FTAs as removing an important tool for "preventing patent applicants from gaining patent monopolies based on weak or erroneous information, for improving the quality and efficiency of patent office examinations, and for safeguarding access to medicines").

194. TPP IP I, supra note 21, art. 8.10. 
person skilled in the art that the applicant was in possession of the claimed invention as of the filing date. ${ }^{195}$

TPP Articles 8.10 and 8.11 reduce flexibility that countries have under TRIPS to design domestic patent disclosure standards to promote a number of important public interest concerns. For example, TPP proposal's mandate that the disclosure be considered "complete" when the disclosure allows the invention to be "made and used" appears to ban best mode requirements, explicitly authorized in Article 29.1 of TRIPS, that would go beyond this threshold to require disclosure of the best mode of making and using the invention. A country might also require, for example, that the description be sufficient to allow a person skilled in the art to be able to apply the technology in the country of the application. Or a country might want to condition approval of the application on disclosure of use of any traditional knowledge or genetic resources in order to facilitate access and benefit sharing. ${ }^{196}$ Finally, a country might require disclosure of the generic name of a pharmaceutical product that incorporates the subject matter of the patent application to ease patent searches on medicines. All of these valid public interest goals in a patent disclosure policy are permitted by TRIPS ${ }^{197}$ but could be prohibited under the U.S. proposal.

\section{F. Industrial Applicability/Utility}

8.12. Each Party shall provide that a claimed invention is industrially applicable if it has a specific, substantial, and credible utility. ${ }^{198}$

TPP Article 8.12 proposes to adopt a U.S.-centric definition of “industrial applicability” on TPP member states. The provision

195. Id. art. 8.11.

196. See generally IUCN/ICTSD, DISCLOSURE REQUIREMENTS: ENSURING MUTUAL SUPPORTIVENESS BETWEEN THE WTO TRIPS AGREEMENT AND THE CBD (2005), available at http://www.iprsonline.org/resources/docs/Disclosure_req_ book.pdf (examining, analyzing, and offering proposals on means to implement disclosure requirements that are compliant with international and national standards).

197. See TRIPS Agreement, supra note 3, art. 29.2 (permitting the requirement of "information concerning the applicant's foreign applications and grants").

198. TPP IP I, supra note 21, art. 8.12. 
appears to be designed to foreclose stricter standards in some jurisdictions that require a showing that the invention will result in an actual industrial product. ${ }^{199}$ By ridding patentability standards from the link to industrial activity, the standard opens the possibility for patenting life forms and medical treatment methods, including new uses of existing medicines or devices, that have no link to industrial activity per se. The standard may also open the door to patenting methods of doing business that do not result in any product.

The parties to the TRIPS negotiation considered and rejected this result. TRIPS Article 27.1 footnote 5 permits, but does not require, members to define "industrial application" to be synonymous with the term "useful."200 TRIPS does not impose any other definition on the term. This was included to permit the United States to continue to implement its own more lax standard on this element of the test for patentability without requiring other countries to adhere to the same standard. ${ }^{201}$ TPP Article 8.12 goes further, potentially exporting the lax U.S. standard to all TPP member states. ${ }^{202}$

\section{G. Data Exclusivity}

9.2. (a) If a Party requires or permits, as a condition for granting marketing approval for a new pharmaceutical product, the submission of information concerning the safety or efficacy of the product, the origination of which involves a considerable effort, the Party shall not, without the consent of a person previously submitting such safety or efficacy information to obtain marketing approval in the territory of the Party, authorize a third person to market a same or a similar product based on:

199. See UNCTAD-ICTSD, supra note 43, at 361 (noting that the United States' broad standard of patentability is at least partly responsible for the high number of patents on businesses' trade secrets in the United States).

200. TRIPS Agreement, supra note 3, art. 27.1 n.5.

201. See Kiliç \& MAYBARDUK, MALAYSIAN LAW COMPARISON, supra note 147, at 2 (stating that TPP Article 8.12 seeks to "impose the U.S. patentability test . . . [which is] broad enough to cover inventions without true industrial application”); Public Citizen TPP VIETNAm Memo, supra note 147, at 3 (commenting that the "U.S. patentability standard of specific, substantial and credible utility is more lenient than the industrial applicability standard used by Vietnam and many other countries").

202. This language is similar to KORUS, supra note 30, art. 18.8.10(b). 
(i) the safety or efficacy information previously submitted in support of the marketing approval; or

(ii) evidence of the existence of the marketing approval for at least five years from the date of marketing approval of the new pharmaceutical product in the territory of the Party. ${ }^{203}$

9.3. Notwithstanding paragraph 2 above, a Party may take measures to protect public health in accordance with:

(a) the Declaration of the TRIPS Agreement and Public Health (WT/MIN(01)/DEC/2) (the “Declaration”);

(b) any waiver of any provision of the TRIPS Agreement granted by WTO Members in accordance with the WTO Agreement to implement the Declaration and in force between the Parties; and

(c) any amendment of the TRIPS Agreement to implement the Declaration that enters into force with respect to the Parties. ${ }^{204}$

9.7. Where a Party provides for a period of data protection for a pharmaceutical product of more than $[5+\mathrm{Y}]$ years pursuant to subparagraph 2(a) or 2(b) of this Article, that Party is not required to implement for that pharmaceutical product subparagraphs 2(c), 2(d) (3year data protection in connection with submission of new clinical information), 5(b)(i) (automatic delay of marketing approval) or 5(d) of this Article (reward for the successful challenge of the validity or applicability of a patent). ${ }^{205}$

TPP Article 9.2 requires implementation of a policy known as "data exclusivity," which is a prohibition of the use of clinical trial data submitted to the government to approve marketing of an initial applicant pharmaceutical product for the subsequent expedited approval of a subsequent product. The issue of access to pharmaceutical test data arises because of requirements that manufacturers must prove the safety, efficacy, and quality of medicines through clinical trials or other data. When a generic manufacturer subsequently attempts to obtain marketing approval for

203. TPP IP II, supra note 28, art. 9.2.

204. Id. art. 9.3 .

205. Id. art. 9.7. 
a therapeutically equivalent medicine, it is normally required to prove only bioequivalence to the already approved drug and Good Manufacturing Practice. In this way, the generic firm relies on the original safety and efficacy data that the regulator has already reviewed and approved, rather than repeating animal and human trials, which would be prohibitively costly, time consuming, and ethically troublesome. ${ }^{206}$

Data exclusivity is not required by TRIPS. ${ }^{207}$ During the negotiation of TRIPS, a U.S. proposal to require data exclusivity was

206. Repetition of clinical trials on human subjects would violate international ethical standards for clinical trials, which forbid doctors to continue experiments on humans when there is already "conclusive proof of positive and beneficial results.” World Medical Association, Declaration of Helsinki: Ethical Principles for Medical Research Involving Human Subjects, 18TH WMA GENERAL ASSEMB. art. 20 (June 1964), http://www.wma.net/en/30publications/10policies/b3/17c.pdf; see also World Health Organization, Global Strategy and Plan of Action on Public Health, InNovation, and Intellectual Property (May 24, 2008), www.who.int/gb/ebwha/pdf_files/A61/A61_R21-en.pdf (committing to "[p]romote ethical principles for clinical trials involving human beings as a requirement of registration of medicines and health-related technologies, with reference to the Declaration of Helsinki"); Aaron Xavier Fellmeth, Secrecy, Monopoly, and Access to Pharmaceuticals in International Trade Law: Protection of Marketing Approval Data Under the TRIPs Agreement, 45 HARV. INT'L L.J. 443, 448 (2004) (criticizing data exclusivity by commenting that "[a]llowing later registrants to free ride on the initial registration prevents wasteful repetition of testing that has already been performed and facilitates rapid development of competition in drug markets”); MSF TPP Issue Brief, supra note 158, at 5 (explaining that data protection or data exclusivity is a "TRIPS-plus provision that restricts access to essential clinical trial data . . . [and] prevent[s] generic manufacturers from using existing clinical research to gain regulatory approval of their medicines, forcing them to perform duplicate clinical trials or wait for the 'data monopoly' period to end").

207. See, e.g., Fellmeth, supra note 206, at 459 (explaining that despite the argument pursued by the United States and the EU, "data exclusivity per se is not required by the plain terms of [TRIPS] Article 39.3" and that "[t]he United Nations Conference on Trade and Development and the World Health Organization (WHO) have adopted consonant interpretations of Article 39.3 as well"); Medecins Sans Frontieres, Data ExClusivity in International Trade AgreEments: What CONSEquences for ACCess to Medicines? 3 (2004), available at http://www.citizen.org/documents/DataExclusivityMay04.pdf (explaining that although TRIPS Article 39.3 says that "WTO Members should protect 'undisclosed test or data' against 'unfair commercial use' and 'disclosure' [n]owhere does TRIPS state that countries should provide exclusive rights to the originator of the data for a given period"). 
specifically considered and rejected by the negotiating parties. ${ }^{208}$ As a result, TRIPS Article 39.3 requires protection only against the "unfair commercial use" of "undisclosed" data required to be submitted for marketing approval of "new chemical entities." 209

TPP Article 9.2(a) and (b), patterned on KORUS Article 18.9.1, abandons the inherent flexibilities in TRIPS Article 39.3 and imposes U.S.-style data monopolies. Rather than banning only the unfair commercial use of information, the data exclusivity proposal bans reference and reliance registration of any new product "based on" safety and efficacy information submitted to it or to another country for an originator product. ${ }^{210}$ This language would appear to foreclose the flexibility in TRIPS that would allow traditional uses of registration data to approve generic medicines as not being an "unfair commercial use" of that data. ${ }^{211}$

208. See DANiEL GerVAis, The TRIPS AgREEMENT: DRAFTing History AND ANALYSIS, 182-85 (1998) (explaining the more restrictive draft provisions with regard to data exclusivity, including definitions that broaden the number of acts that are considered to be in violation of the provision); MSF TPP Issue Brief, supra note 158, at 5 (stating that the United States continuously advocates for data exclusivity measures to be implemented with a minimum term of five years, and may lobby for up to twelve).

209. Thus, test data under TRIPS must be protected only if: (1) national authorities require its submission; (2) it is undisclosed and not already public, (as many clinical trial results in the United States are by virtue of state and local clinical trial registry laws); and (3) it concerns a new chemical entity, i.e., the undisclosed data is "the result of significant investment," proof that could be required.

210. See TPP IP II, supra note 28, art. 9.2(b) (stipulating that the drug regulatory authority may neither reference previously submitted clinical trial data nor rely on evidence that the product was previously approved either domestically or in another territory without consent).

211. Carlos Correa, Protection of Data Submitted for the Registration of Pharmaceuticals: Implementing the Standards of the Trips Agreement, SOUTH CENTRE/WHO at 5 (2002), available at http://apps.who.int/medicinedocs/pdf/ h3009ae/h3009ae.pdf (explaining that "[c]ountries can meet their obligations . . . under Article 39.3 by barring 'dishonest' uses of test data”); see also Carlos M. Correa, Protecting Test Data for Pharmaceutical and Agrochemical Products Under Free Trade Agreements, in Negotiating Health: InTEllectual Property AND ACCESS to MEdicines 81, 84-85 (Pedro Roffe et al. eds., 2006) (explaining that, under TRIPS, the reliance on prior reviewed data by a regulation authority to approve a generic version of the same drug need not be considered a "commercial use" of the data). See generally Brook K. Baker, Ending Drug Registration Apartheid: Taming Data Exclusivity and Patent/Registration Linkage, 
The data exclusivity provision abandons the TRIPS provision that protection only be required for "undisclosed" information, instead requiring protection for all data. Often, clinical trial data is made public by various entities, including funders, registration authorities, and academic publication. Thus, the proposal would require granting of exclusive rights for information that is already in the public domain and is in no sense a trade secret.

The data exclusivity proposal also abandons the TRIPS rule that requires protection only for "new chemical entities," instead requiring protection of new pharmaceutical products that might incorporate existing chemical entities. ${ }^{212}$ In addition, TPP Article 9.2(c) and (d) both require an additional three-year term of exclusivity for data submitted for approval of a new use or form of an approved chemical entity. ${ }^{213}$ As in U.S. law, the proposal permits successive three-year data exclusivity extensions, meaning that data exclusivity, like patents, can be evergreened.

The U.S. proposal abandons many data-exclusivity flexibilities adopted in the 2007 New Trade Policy ${ }^{214}$ and, thereafter, granted to Peru and Colombia in their FTAs with the United States. ${ }^{215}$ Like

34 AM. J.L. \& MED. 303 (2008) (discussing the U.S. pharmaceutical industry's pursuit to establish protection of rights related to drug registration, the consequences, and recommending steps developing countries and Congress should take to ensure broad access to life-saving medicines); Musungu \& Oh, supra note 138, 65-67 (Aug. 2005); Judit Rius-Sanjuan, James Love, \& Robert Weissman, Protection of Pharmaceutical Test Data: A Policy Proposal, Consumer PROJECT ON TECH. (Nov. 2006), available at http://www.cptech.org/ip/health/data/CPTechTest-Data.pdf.

212. TPP IP II, supra note 28, art. 9.2(a)-(b).

213. Id. art. 9.2(c)-(d); see also KORUS, supra note 30, art. 18.9.2 (providing a three-year exclusivity term from the date of marketing approval and new clinical information for pharmaceuticals, as well as a ten-year exclusivity term for agricultural chemical products).

214. See Bipartisan Agreement on Trade Policy, supra note 176, at 3 (clarifying that "the period of protection for test data for pharmaceuticals by developing country FTA partners will generally not extend beyond the period that such protection is available for the same product in the United States, coupled with a provision that will encourage our partners to process marketing approval applications for innovative drugs in a timely manner”).

215. Trade Promotion Agreement art. 16.10.2, U.S.-Colom., Nov. 22, 2006, http://www.ustr.gov/webfm_send/1336 [hereinafter U.S.-Colombia FTA]; United States-Peru Trade Promotion Agreement, supra note 176, art. 16.10.2. This early 
TRIPS Article 39.3, the Peru and Colombia FTAs' data exclusivity provisions are limited to new chemical entities and are required to run only for a "reasonable period," which "shall normally mean five years." ${ }^{216}$ The U.S. TPP proposal applies to "new products” and must run for "at least" five years. The Peru and Colombia FTAs also included a use-it-or-lose-it restriction on data exclusivity, whereby if a Party relies on marketing approval granted by the U.S. Food and Drug Administration and if the Party grants approval within six months of an application for marketing approval, the five-year data exclusivity period begins when the drug was first approved in the United States. ${ }^{217}$ This flexibility can help thwart the common experience, where a company files for registration in a third country only after the original term of data exclusivity has lapsed in the United States - effectively making the monopoly in the third country run beyond the same period of exclusivity in the United States. All of these data-exclusivity flexibilities are missing from the U.S. TPP proposal.

TPP Article 9.7 contains another provision new to U.S. FTAs encouraging even longer periods of data exclusivity. The provision states that parties would be exempted from the three-year data protection terms for submission of new clinical information, automatic delays of marketing approval in their patent/registration linkage mechanisms, and rewards for successful challenges to patent rights if they adopt periods of data exclusivity for new pharmaceutical products for an undefined duration ("Y") in excess of five years. If TPP provisions allow pharmaceutical companies to get substantially longer data exclusivity-particularly through mechanisms for evergreening exclusivity, such as the twelve years of exclusivity granted in the United States for biologics-companies won't have to rely on patent protections to obtain effective marketing

filing requirement applied only if Peru or Colombia granted marketing approval based in whole or in part on evidence of marketing approval in the United States. See Charles B. Rangel, Moving Forward: A New, Bipartisan Trade Policy That Reflects American Values, 45 HARV. J. ON LEGIS. 377, 404 (2008) (describing changes to data exclusivity demands required by the New Trade Policy).

216. U.S.-Colombia FTA, supra note 215, art. 16.10.2(a); United States-Peru Trade Promotion Agreement, supra note 176, art. 16.10.2(a).

217. U.S.-Colombia FTA, supra note 215, art. 16.10.2(c); United States-Peru Trade Promotion Agreement, supra note 176, art. 16.10.2(c). 
monopolies. In fact, data monopolies of sufficient length will be superior to patents from the perspective of pharmaceutical firms because data monopolies give the same, or higher, level of monopoly protection without the requirements and expenses associated with proving that a product meets the relatively high standards for patentability.

The TPP proposal does include one flexibility from the U.S.-Peru and U.S.-Colombia FTAs. TPP proposed Article 9.3 provides authority for countries to adopt exceptions to data exclusivity requirements "to protect public health in accordance with" the Doha Declaration on TRIPS and Public Health including, any waiver or amendment of TRIPS to facilitate the Declaration. ${ }^{218}$ This provision is modeled on the amendment to the Peru and Colombia FTAs after the 2007 New Trade Policy. ${ }^{219}$ The provision is potentially helpful in providing for a broad public health exception to any data exclusivity requirement included in the agreement. Particularly, as interpreted in the context of the May 2007 Agreement that the Peru language was meant to effectuate, ${ }^{220}$ the provision should be read to provide for rights to override data exclusivity either (1) to ensure rights to obtain marketing approval when a compulsory license or government use license is issued, or (2) to have a compulsory license-like exception to data exclusivity and patent/registration linkage, even if no patent bar is in place. However, those rights were explicitly and textually granted in the Peru and Columbia FTAs but only implied in the TPP exception.

\section{H. Access Window}

9.4. A Party that requires or permits an applicant to obtain approval for marketing a new pharmaceutical product in its territory by relying, in whole or in part, on the prior approval of the pharmaceutical product by the regulatory authority in another territory may, as a condition for providing the period of data protection specified in subparagraph 2(b) or

218. TPP IP II, supra note 28, art. 9.3.

219. E.g., United States-Peru Trade Promotion Agreement, supra note 176, art. $16.10(2)(\mathrm{e})$.

220. See United States Trade Representative, TRAdE FACTS: BIPARTISAN TRADE DEAL 3 (May 2007), available at http://www.ustr.gov/sites/default/files/uploads/ factsheets/2007/asset_upload_file127_11319.pdf. 
2(d), require an applicant that has submitted an application for marketing approval consistent with said subparagraphs to commence the process of obtaining marketing approval for that pharmaceutical product within [X] years of the date of first marketing approval of the same pharmaceutical product in another Party. ${ }^{221}$

Sometime before the leak of the medicines provisions of the U.S. proposal, the USTR issued a press release describing a TradeEnhancing Access to Medicines proposal, including what it called an "Access Window" policy. ${ }^{222}$ The memo stated that the Access Window was "designed to deploy the tools of trade policy to promote trade in, and reduce obstacles to, access to both innovative and generic medicines, while supporting the innovation and intellectual property protection that is vital to developing new medicines and achieving other medical breakthroughs." 223 The memo immediately became the subject of criticism for both its obfuscation of substance and its non-transparent process. ${ }^{224}$ Now that the actual text of the Access Window has been leaked, it is clear that its main impact will be to revoke added flexibilities endorsed by the May 2007 New Trade Policy and ease registration access for innovators, with no real benefit for access to generic medicines.

As discussed above, the general rule under the TPP proposal is that members must grant patent extensions for regulatory delays, exclusivity periods for clinical trial data used to approve pharmaceuticals, and (as discussed below) the "linkage" of patent and registration processes to block marketing of a competing medicine whenever a patent is claimed. The Access Window policy provides countries with the option of having marketing approval procedures that rely, in whole or in part, on the fact of marketing approval/registration in another country. ${ }^{225}$ This makes registration

221. TPP IP II, supra note 28, art. 9.4.

222. Trans-Pacific Partnership Trade Goals to Enhance Access to Medicines, supra note 174.

223. Id.

224. See Leaked Trans-Pacific Free Trade Agreement Texts Reveal Demands, supra note 26 (stating that the leaked proposal allows a broadening of pharmaceutical companies' exclusive rights to clinical trial data, lengthens periods of exclusivity, and weakens regulation of goods and services).

225. See TPP IP II, supra note 28, arts. 8.6(e), 9.4, 9.6 (noting that countries are not required to create the TEAM Access Window, but they may do so in a narrow 
much easier in the "reliance" countries, since complete dossiers of safety and efficacy information would not be required. To further incentivize the speedy use of such processes, the policy limits the grant of patent term extensions, data protection, and patent/registration linkage (hereinafter "TRIPS-plus medicines provisions") for applicants who use the reliance mechanism and fail to register their products in the country within a yet-to-be-determined number of years from the first registration in another member state. ${ }^{226}$

Paradoxically, speedier registration of brand name drugs will not do anything to increase the affordability of medicines in TPP member countries. In this sense, the U.S. proposal and "access to medicines" advocates use very different definitions of the term "access." For the latter, the term is used primarily to refer to the presence of affordable medications within the health system, primarily in the form of low cost generic medicines. The United States uses the term to refer the presence of any medication for a specific condition in the subject country, even if that medication is unaffordable to most patients. Indeed, the proposal will hamper affordability concerns by granting additional TRIPS-plus medicines provisions that will elongate exclusivity periods, thereby keeping generic medicines out of the market for longer periods of time.

There are potential benefits to countries that want to provide inducements to pharmaceutical companies to bring their new medicines to market more quickly. To the extent that differential registration standards and processes have disincentivized innovators from quickly launching new products, simplification might speed up market entry. Pharmaceutical companies have long chafed over the

subset of cases-where the party "requires or permits an applicant to obtain approval for marketing a new pharmaceutical product in its territory by relying, in whole or in part, on the prior approval of the pharmaceutical product by the regulatory authority in another county").

226. See id. art. 8.6(e) (applying Access Window restrictions only with respect to article 8.6(c) extensions-those caused by unreasonable delays in the marketing approval process); id. art. 8.6(e) n.2 (claiming that the length of the TEAM Access Window should enhance certainty, provide incentive for the diffusion of pharmaceutical products, respect commercial consideration, and account for challenges faced by smaller or lesser experienced applicants or the time needed to assess country-specific safety and efficacy issues). 
lack of harmonization of drug regulatory authorities' marketing approval requirements, standards, and processes. The multinational pharmaceutical industry would like a registration process that is similar to what the WIPO Patent Cooperation Treaty provides: an easy-to-use, standardized mechanism to initiate marketing approval applications before national drug regulatory authorities. ${ }^{227}$ Article 9.8(a) provides the industry with the easy-to-use, fast-track mechanism it has desired. But the desirability of earlier product introduction should have nothing to do with a tradeoff involving greater IP protections that extend and strengthen drug company patent and data-related monopolies. The Access Window is promoted as benefitting TPP parties, but it is clear that the true beneficiaries are innovator companies. ${ }^{228}$

The proposal is hampered by a large number of drafting and conceptual problems. To begin with, the proposal gives the unilateral ultimate power of whether to utilize the U.S. "Access

227. Indeed, there is a separate annex on pharmaceutical regulatory harmonization in the U.S. TPP proposals. Trans-Pacific Partnership [TPP]—U.S. Introduction to Proposed TBT Annexes on Medical Devices, Pharmaceutical Products and Cosmetic Products (Mar. 4, 2010), available at http:/www.citizenstrade.org/ctc/wp-content/uploads/2011/10/TransPacificTBTw MedicalAnnexes.pdf (extending the industry's intentions and interests); id. annex IV ๆף 8-9 (seeking TPP partners' agreement to use the ICD Common Technical Document as the standardized harmonized form to initiate marketing approval requests).

228. The problem is not simply making a big deal out of very minor processes; the Access Window provisions are also likely to result in pressure from the United States and Big Pharma for what is essentially a harmonized global registration system, such as those suggested in the Proposed TBT Chapter Annex on Pharmaceutical Products. We can now see that the United Sates is arguing with trade partners that they should vicariously grant registration in their countries based on prior marketing approval by drug regulators in the United States, Europe, or Japan. If countries are tempted to adopt full-scale reliance registration, there is a risk that they will have reduced ability to assess medicines in light of the particular patient risks and benefits in their countries. Although reliance registration may have certain advantages for countries with weak regulatory authorities, and although lack of procedural harmonization adversely affects both innovator companies and generics, countries are being asked to give up far too much TRIPSplus territory for a quick-registration Access Window that doesn't require fast completion and prosecution of registration applications and that results in greater and longer monopoly protections that will inevitably lead to higher prices and reduced generic competition. 
Window" to patent holding pharmaceutical companies. Under the proposal, the pharmaceutical company seeking initial registration can decide to apply for marketing approval by submitting a full registration dossier that does not rely, in whole or in part, on the fact of prior registration elsewhere, so long as such an option is provided for under national law. In such cases, they would receive the full benefits of the TRIPS-plus medicines provisions whether or not they applied for registration approval within the Access Window. Alternatively, they can rely in whole or in part on the fact of registration elsewhere and get the full benefit of the TRIPS-plus medicines provisions merely by initiating a filing within the time period of the Access Window.

The latest proposal from the Pharmaceutical Research and Manufacturers of America (PhRMA) to the U.S. trade negotiators is that the "window" period within which applications must be filed be a full six years. ${ }^{229}$ This lengthy time period would effectively negate any real advantages from the Access Window in terms of speeding up registration. PhRMA proposed this protracted window based on a study of registration data from fifteen emerging economies, which found that $93 \%$ of companies register new medicines in all the countries within six years of their first registration (normally in the United States). ${ }^{230}$ Negotiating partners could wonder why it is appropriate to rely on the history of delayed registration practices when the Access Window is advertised as being designed to speed up registration. More to the point, the proposed six-year window term would allow pharmaceutical countries to continue to game product introduction primarily for commercial reasons, at the expense of patient access.

TPP Article 9.8(a) additionally requires the TPP country to consider the Access Window to be met through mere initiation of

229. PhRMA Engages with USTR, Congress to Justify TPP Access Window Proposal, WORLD TRADE ONLINE (May 3, 2012), http://insidetrade.com/ 201205032397788/WTO-Daily-News/Daily-News/phrma-engages-with-ustr-

congress-to-justify-tpp-access-window-proposal/menu-id-948.html (explaining that, of the fifteen countries-which include Argentina, Brazil, Mexico, Egypt, Saudi Arabia, South Africa, Turkey, Russia, China, India, Indonesia, South Korea, and Taiwan-only Singapore and Malaysia are engaged in the TPP talks).

230. See id. 
marketing registration. A company may take advantage of the window even if it does no more than submit to a TPP member state "evidence of prior approval of the product in another Party."231 This is an extremely low threshold, permitting a registration application to be deemed filed even if it does not contain sufficient information to actually approve the drug.

Ultimately, this proposal appears to have little chance of entering the final agreement. There have been reports of widespread dissatisfaction with the proposal among TPP negotiating partners. Even the United States' strongest ally, Australia, has rejected the offer. Accordingly, the issue of whether the TPP will include the most controversial TRIPS-plus requirements on medicines beyond the modifications of the U.S. standard FTA proposals by the May 2007 New Trade Policy remains an open question.

\section{Patent/Registration Linkage}

9.5. Where a Party requires or permits, as a condition of approving the marketing of a pharmaceutical product, persons, other than the person originally submitting safety or efficacy information, to rely on that information or on evidence concerning safety or efficacy information for a product that was previously approved, such as evidence of prior marketing approval in another territory, each Party shall:

(a) provide a transparent and effective system to:

(i) identify a patent or patents covering an approved pharmaceutical product or its approved method of use; and

(ii) provide notice to a patent holder of the identity of another person who intends to market, during the term of the identified patent or patents, a product that is the same as, or similar to, the approved pharmaceutical product referenced in subparagraph 5(a)(i).

(b) unless such other person agrees to defer the marketing of the product until after the expiration of an identified patent, ensure that a patent holder may seek, prior to granting of marketing approval to an allegedly infringing product, available remedies by providing:

231. TPP IP II, supra note 28, art. 9.8.2(a). 
(i) an automatic delay of the grant of marketing approval that remains in place for a period of time designed to ensure sufficient opportunity to adjudicate disputes concerning the validity or infringement of allegedly infringed patents; and

(ii) judicial or administrative procedures, including effective provisional measures, to allow for the timely adjudication of disputes concerning the validity or infringement of an allegedly infringed patent.

(c) if such other person's product has been found to infringe a valid patent identified pursuant to subparagraph (a), provide measures that operate to prohibit the unauthorized marketing of that product prior to the expiration of the patent.

(d) when a Party delays the grant of marketing approval consistent with subparagraph 5(b)(i), provide an effective reward, consistent with the provisions of this Agreement, for the successful challenge of the validity or applicability of the patent. ${ }^{232}$

TPP Article 9.5 contains a TRIPS-plus proposal on what is called patent/registration linkage. Although patent/registration linkage is not mentioned in TRIPS and is not required in many countries, including most TPP negotiating countries, ${ }^{233}$ it has become a common and contested feature of U.S. FTAs. ${ }^{234}$

"Linkage" refers to requirements that safety and efficacy marketing authorities (e.g., the U.S. Food and Drug Administration) do not register generic copies of medicines for which there is a patent claimed by another supplier. This is an added enforcement process favored by patent holders. It permits them to use patent claims to block the

232. Id. art. 9.5.

233. See Public Citizen TPP Vietnam Memo, supra note 147 (explaining that "Vietnamese law contains no provision that links the patent system to the drug marketing approval process" and that many U.S. FTAs require patent linkage, which "shifts burdens of early patent enforcement to drug regulatory authorities"); see also KILIÇ \& MAYBARDUK, MALAYSIAN LAW COMPARISON, supra note 147 ("Malaysian law contains no provision that links the patent system to marketing approval process.”); $c f$. KiLIÇ \& MAYBARDUK, AUSTRALIAN LAW COMPARISON, supra note 147 (explaining that although AUSFTA introduced patent linkage in Australia, Australia sought to limit its effect through statutory measures imposing penalties for linkage evergreening).

234. See, e.g., KORUS, supra note 30, art. 18.9.5. 
marketing of products without the need to sue the alleged infringer in courts to enforce the patent rights. Generics will then be required to challenge the patent claims in court and wait until the completion of the challenge (for each claim) in order to reach the market, which may take many years. The costs of litigation and delay may be so high as to provide an effective deterrent to generic companies entering a market where there are claimed patents - even where underlying patents are clearly invalid. Without linkage, the patent holder would normally be required to wait until the generic company marketed a product in order to bring an enforcement action in court, and the court could permit the generic to remain on the market until any challenges are completed. Linkage systems reverse the onus, forcing the generic company, blocked from access to the market, to affirmatively sue the patent holder in order to gain market access.

Patent/registration linkage turns drug regulatory authorities into patent-policing agents, who aid patent holders in the enforcement of their private rights. Moreover, the automatic stays can be abusive. The introduction of linkage systems in the United States in the 1980s led to gaming by patent holders through the filing of new (often baseless) applications for patents to use automatic stays of registration to block generic entry. ${ }^{235}$ In response to these evergreening strategies, U.S. law now limits patent holders to one automatic stay to litigate any patent claims ${ }^{236}$ - a requirement not included in the TPP proposal.

Linkage systems might interfere with the effective use of compulsory licenses. This is because licensees could be prevented from marketing their generic equivalents after receiving a license on

235. See Federal Trade Commission, Generic Drug Entry Prior to Patent Expiration: An FTC Study (2002), www.ftc.gov/os/2002/07/genericdrugstudy.pdf; see also Robert Weissman, The Evergreen Patent System: Pharmaceutical Company Tactics to Extend Patent Protections, Multinational Monitor, June 2002; Marc Kaufman, Drug Firms' Deals Allowing Exclusivity-Makers of Generics Being Paid to Drop Patent Challenges, FTC Review Finds, WASH. Post, Apr. 25, 2006; Federal Trade Commission, Agreements Filed with the Federal Trade Commission under the Medicare Prescription Drug, Improvement, and Modernization Act of 2003: Summary of Agreements Filed in FY 2005-A Report by the Bureau of Competition (2006), available at www.ftc.gov/os/2006/04/ fy2005drugsettlementsrpt.pdf.

236. 21 U.S.C. § 355(j)(2), (j)(5) (2012). 
some patent claims, by virtue of the linkage provisions preventing product registration.

Serious questions have been raised as to what would be an effective reward for challenging the validity of a patent in TPP member countries. In the United States, a 180-day period of generic exclusivity is given to the first successful challenger of a patent, enabling the generic firm to be the only competitor with the branded drug during that time, which permits the generic firm to charge higher prices than are possible in a truly competitive market. ${ }^{237}$ For the policy to work to incentivize patent challenges, the period of exclusivity must provide sufficient income, at least, to offset the added litigation costs associated with challenging patents. However, generic firms in Australia and other TPP member countries have presented analyses to TPP negotiators showing that the same policies would not work in TPP member countries because their small size would yield far lower rewards from periods of market exclusivity. ${ }^{238}$

\section{J. Doha Declaration on TRIPS and Public Health}

Article $[X]$.

1. The Parties affirm their commitment to the Declaration on the TRIPS Agreement and Public Health (WT/MIN(01)/DEC/2).

2. The Parties have reached the following understandings regarding this Chapter:

(a) The obligations of this Chapter do not and should not prevent a Party from taking measures to protect public health by promoting access to medicines for all, in particular concerning cases such as HIV/AIDS, tuberculosis, malaria, and other epidemics as well as circumstances of extreme urgency or national emergency. Accordingly, while reiterating their commitment to this Chapter, the Parties affirm that this Chapter can and should be interpreted and

237. See generally Federal Trade Commission, AuthORIZEd GENERIC DRUGS: Short-Term EfFects \& Long-Term Impact 98 (Aug. 2011) (analyzing the relationship between relative drug price and the number of manufacturers with exclusivity).

238. See Sean Flynn, Intellectual Property TPP Talks Stall in Melbourne, INFOJUSTICE.ORG (Mar. 12, 2012), http://infojustice.org/archives/8847 (describing presentations by generic firms and including a link to presentation slides). 
implemented in a manner supportive of each Party's right to protect public health and, in particular, to promote access to medicines for all.

(b) In recognition of the commitment to access to medicines that are supplied in accordance with the Decision of the General Council of 30 August 2003 on the Implementation of Paragraph Six of the Doha Declaration on the TRIPS Agreement and Public Health (WT/L/540) and the WTO General Council Chairman's statement accompanying the Decision (JOB(03)/177, WT/GC/M/82) (collectively, the "TRIPS/health solution"), this Chapter does not and should not prevent the effective utilization of the TRIPS/health solution.

(c) With respect to the aforementioned matters, if an amendment of the TRIPS Agreement enters into force with respect to the Parties and a Party's application of a measure in conformity with that amendment violates this Chapter, the Parties shall immediately consult in order to adapt this Chapter as appropriate in the light of the amendment. ${ }^{239}$

The U.S. proposal contains an overarching Article [X] which references the Doha Declaration on the TRIPS Agreement and Public Health. ${ }^{240}$ Although it is standard in boilerplate language to acknowledge a unanimous WTO commitment made nearly ten years ago, and although acknowledgement is superior to exclusion or rejection, the boilerplate does not make up for an absence of specific clarifying commitments about how countries can operationalize Doha to overcome the many TRIPS-plus provisions in the TPP proposal.

It is important that any affirmation of the Doha Declaration not be limited to certain infectious disease epidemics and to a narrow subset of public health needs that can be classified as matters of "extreme urgency" or "national emergency." The burden of noncommunicable chronic diseases is escalating throughout the world, particularly in low- and middle-income countries, where the cost of many chronic disease medicines, including those for cancers,

239. TPP IP II, supra note 28, art. [X].

240. World Trade Organization, Declaration on the TRIPS Agreement and Public Health of 14 November 2001, WT/MIN(01)/DEC/2 (2001) [hereinafter Doha Declaration] (explaining in paragraph 4 that the Parties "reaffirm the right of WTO members to use, to the full, the provisions in the TRIPS Agreement, which provide flexibility for this purpose"). 
psychiatric illnesses, and other illnesses, is too expensive for individual patients, insurers, and governments. ${ }^{241}$ Likewise, many developing countries face a persistent crisis with respect to neglected tropical diseases where newer, more expensive medicines might again be priced at unaffordable levels. ${ }^{242}$ The United States' intent to purposefully exclude non-infectious chronic disease can be inferred from its efforts at the UN High Level Meeting on NonCommunicable Diseases to ensure that they were not described as an "epidemic" or "emergency" and that no mention of the Doha Declaration appeared in the meeting's outcome. ${ }^{243}$

The affirmation that the U.S. TPP proposals on medicines do not prevent a Party from taking measures to promote access to medicines may set a dangerous precedent for the interpretation of the Doha Declaration. ${ }^{244}$ As described throughout this article, there are numerous TRIPS-plus standards in the TPP proposal that will predictably lead to higher prices and lower availability of

241. See, e.g., Felicia Marie KNaUl et Al., Closing the CANCER Divide: A BLUEPRINT TO EXPAND ACCESS IN LOW \& MidDLE INCOME COUNTRIES: A REPORT of the Global Task ForCe on EXPANDEd ACCess to CANCER CARE AND CONTROL 164 (2d ed. 2011), available at http://ghsm.hms.harvard.edu/uploads/ pdf/ccd_report_111027.pdf (estimating the costs of covering chemotherapy for unmet needs of several cancers, including a breakdown between the costs for highversus low-income counties); World Health Organization [WHO], NONCOMMUNICABLE DiseASes COUNTRy PROFILES 2011 5-9 (2011), available at http://whqlibdoc.who.int/publications/2011/9789241502283_eng.pdf.

242. See WHO, Working to Overcome the Global Impact of Neglected TROPICAL DISEASES, at iv (2011), available at http://www.who.int/neglected_ diseases/2010report/WHO_NTD_report_update_2011.pdf (noting, for example, that dracunculiasis is on the verge of being eradicated thanks to sizeable donations from the Government of the United Kingdom, and that the introduction of antibiotic therapy has reduced by $30 \%$ the need for people affected by Buruli ulcer to get surgery).

243. William New, Questions Arise over UN Policy on Non-Communicable Diseases and IP Rights, 2-3 IP-WATCH.ORG (Sept. 16, 2011, 10:47 PM), http://www.ip-watch.org/weblog/2011/09/16/questions-arise-over-un-policy-onnon-communicable-diseases-and-ip-rights/ (these efforts were ultimately successful, though there were two references to countries' need to use intellectual property flexibilities to access NCD medicines); see U.N. President of the G.A., Draft G.A. Res., Political Declaration of the High-level Meeting of the General Assembly on the Prevention and Control of Non-communicable Diseases, U.N. Doc. A/66/L.1 (Sept. 16, 2011).

244. TPP IP II, supra note 28, art. [X].2(a). 
pharmaceutical products, especially in developing countries. ${ }^{245}$ Implicitly defining these standards as compliant with the Doha Declaration significantly limits the express statement in the Declaration that TRIPS flexibilities can and should be available "to the full." ${ }^{246}$ Doha should be read to prevent the proposal or adoption of any TRIPS-plus measure that would positively affect public health and access to medicines for all. ${ }^{247} \mathrm{~A}$ better provision fully embracing Doha would create an explicit and operational exception to any TPP provision, on the basis that the member country concludes that the provision would impede access to affordable medicines or the promotion of public health objectives.

The declaration that the agreement "does not and should not prevent the effective utilization of the TRIPS/health solution" is also exceedingly narrow. ${ }^{248}$ What the United States refers to as the TRIPS/health solution is a current waiver of provisions of the TRIPS Agreement that allows the export and import of medicines produced under special compulsory licenses to a country with little or no manufacturing capacity. ${ }^{249}$ Calling this “the TRIPS/health solution” is a

245. Chief among them may be: (1) lowered patent standards, presumptions of valid patent status, and express obligations to grant patents for new uses and new forms of existing products; (2) elimination of rights of pre-grant opposition; (3) extension of patent terms beyond the TRIPS requirement of twenty years to compensate for delays in granting patents and/or in granting marketing approval; (4) five-year data exclusivity following the first registration of a new pharmaceutical product with rights to evergreen data exclusivity for an additional three years whenever new clinical trial data is submitted; (5) mandatory patent/registration linkage giving patent holders a right to prevent registration of alleged patent-infringing products no matter how weak the patent claim is; (6) unconscionable restrictions on government price control and therapeutic formulary policies; and (7) multiple TRIPS-plus enforcement measures.

246. Doha Declaration, supra note 240, ๆ 4.

247. See TRIPS Agreement, supra note 3, arts. 27, 33, 39.3 (adopting strict patentability criteria under TRIPS Article 27, avoiding patent extensions beyond twenty years in implementing TRIPS Article 33, avoidance of data exclusivity in the implementation of TRIPS Article 39.3, and the avoidance of any other TRIPSplus protection or enforcement measure that will increase market power of brandname pharmaceutical companies).

248. TPP IP II, supra note 28, art. [X].(b).

249. Paragraph 6 of the Doha Declaration required the development of a quick and expeditious mechanism allowing the export/import of medicines to countries that had insufficient pharmaceutical capacity locally to either produce medicines that were not patented or those authorized pursuant to a properly issued 
misnomer. It is an effort to address only part of the problem that the globalization of patents on pharmaceutical products causes for public health and access to medicine, especially in developing countries. The TRIPS waiver narrowly focuses on the problem caused by TRIPS Article 31(f)'s requirement that a compulsory license be used for the predominant supply of a domestic market, rather than for export. Its provisions are unduly complex, ${ }^{250}$ and have been used only once, as a trial run between two countries that have not used it again. ${ }^{251}$ There is no evidence that the proposed TRIPS/health solution, if finally adopted, will in fact promote global access to medicines, a fact articulated by Ecuador at the most recent TRIPS Council meeting. ${ }^{252}$ Many TPP member states may desire to maintain flexibilities to explore other options for meeting the particular challenges of supplying non-producing countries, including: (1) export of unlimited quantities through compulsory licenses issued on competition grounds (TRIPS

compulsory license or government use order. Doha Declaration, supra note 240, ๆ 6. Article 31(f) of the TRIPS Agreement had created a major barrier for these nonproducing importers because it restricted the quantity of medicines produced pursuant to a compulsory license that could be exported to other countries to "nonpredominant" amounts, presumably less than $50 \%$ of output. TRIPS Agreement, supra note 3, art. 45. Unfortunately, the TRIPS/Health solution that was adopted on August 30, 2003, is painfully complex. See Fredrick M. Abbott, The WTO Medicines Decision: World Pharmaceutical Trade and the Protection of Public Health, 99 AM. J. INT’L L. 317, 317 n.5 (2005) (“Officially, the World Health Organization (WHO) applauded the [TRIPS/Health solution], noting that the key to success lay in its implementation .... Privately, some individuals in the Essential Drugs and Medicines Police (EDM) Division worried about the bureaucratic complications involved in using it.").

250. See Brook K. Baker, Arthritic Flexibilities for Accessing Medicines: Analysis of WTO Action Regarding Paragraph 6 of the Doha Declaration on the TRIPS Agreement and Public Health, 14 IND. INT'L \& COMP. L. REV. 613, 617 (2003) (noting that, for many countries, "local production is impossible and importation from exporters is increasingly restricted because of a requirement in TRIPS that countries bypassing patent rights for particular medicines must produce predominately for their own domestic markets rather than for export”).

251. See South Centre, The Doha Declaration on TRIPS and Public Health Ten Years Later: The State of Implementation, http://www.southcentre.org/ index.php?option=com_content\&view=article\&id=1657\%3Asb58\&catid $=144 \% 3 \mathrm{~A}$ south-bulletin-individual-articles\&Itemid=287\&lang=en (last visited Nov. 29, 2012) (discussing constraints of using the so-called “August 30 Decision”).

252. See Review of "Para 6" System, ACTA Feature at TRIPS Council, THIRD WORLD NETWORK (Nov. 2, 2011), http://www.twnside.org.sg/title2/intellectual_ property/info.service/2011/ipr.info.111101.htm. 
Article 31(k); (2) export of non-predominant quantities pursuant to an ordinary TRIPS Article 31 license; or (3) export to non-producing countries through an easy-to-use TRIPS Article 30 limited exception.

\section{ENFORCEMENT}

The TPP is the latest front in the "enforcement agenda." 253 The enforcement agenda grows out of perceptions of incredibly high intellectual property infringement rates in many countries, particularly with respect to digital copyright "piracy."254 Intellectual property-intensive industries have been pressing for heightened international rules that would raise the value of their rights by "making enforcement of intellectual property rights in courts, at borders, by the government and by private parties easier, less costly and more 'deterrent' in the level of penalties." ${ }^{255}$ By doing so, the enforcement agenda implicates public interest concerns in at least two major ways. First, the lowering of evidentiary and other thresholds needed for government-sanctioned penalties (from the seizure of property to the implementation of criminal penalties) implicates due process and other procedural protections against unwarranted deprivations of liberty and property. The raising of such risks, harmful in its own right, may deter lawful competition and expression. Second, the enforcement agenda often builds itself upon a set of substantive rules that are unbalanced and incentivize the exclusionary pricing of intellectual property-protected goods. Such pricing is itself a major cause of piracy, counterfeiting, and other intellectual property infringement that the rules attempt to combat. ${ }^{256}$

253. See generally Sell, Global IP Upward Ratchet, supra note 8 (providing an overview of the "IP Maximalist" enforcement agenda and current forums said industries currently turn to in advancing IP protection).

254. See generally MEdia PiRACY In EMERGIng ECONOMieS, supra note 32.

255. Sean Flynn \& Bijan Madhani, ACTA and Access to Medicines, AM. UnIV. Wash. Coll. Of Program on Info. Justice \& Intell. Prop. (PIJIP Research Paper Ser. No. 22, 2011), available at http://digitalcommons.wcl.american.edu/cgi/ viewcontent.cgi?article $=1024 \&$ context=research.

256. See Media Piracy in Emerging Economies, supra note 32, at i (linking incredibly high piracy rates in many middle-income countries to exclusionary pricing or protected content); Kevin Outterson \& Ryan Smith, Counterfeit Drugs: The Good, the Bad, and the Ugly, 16 AlB. L.J. SCI. \& TeCH. 525, 526 (2006) (identifying "the underlying cause of drug counterfeiting as the legal system of intellectual property laws”). 


\section{A. General Obligations}

10.1 The Parties understand that a decision that a Party makes on the distribution of enforcement resources shall not excuse that Party from complying with this Chapter. ${ }^{257}$

In the TRIPS negotiations, a major point of contention was a resistance by many countries, including many developing countries, to force countries to shift more resources toward intellectual property enforcement. The concern led to the adoption of Article 41.5 in TRIPS, originally offered by the Indian delegation, ${ }^{258}$ stating:

It is understood that this Part does not create any obligation to put in place a judicial system for the enforcement of intellectual property rights distinct from that for the enforcement of law in general, nor does it affect the capacity of Members to enforce their law in general. Nothing in this Part creates any obligation with respect to the distribution of resources as between enforcement of intellectual property rights and the enforcement of law in general. ${ }^{259}$

The U.S.-proposed Article 10.1 for TPP does not revoke or amend TRIPS Article 41.5, but it shifts its focus quite dramatically. Instead of making it clear that the agreement "creates no obligation to shift resources" toward intellectual property enforcement, ${ }^{260}$ the U.S. proposal appears to suggest that some minimum amount of resource shifting may be required-providing that resource-allocation problems "shall not excuse that Party from complying with this Chapter."261

The public interest concern arises here because "resources needed for enforcing IPRs are invariably scarce.”262 Decisions to escalate public resource expenditures on intellectual property enforcement can take away from other law enforcement priorities or public investment priorities. Such choices are particularly "difficult in developing

257. TPP IP I, supra note 21, art. 10.1.

258. UNCTAD-ICTSD, supra 43, at 585 (describing the article as "one of the few provisions in Part III where developing countries' views made a difference").

259. TRIPS Agreement, supra note 3, art. 41.5.

260. UNCTAD-ICTSD, supra note 43, at 634.

261. TPP IP I, supra note 21, art. 10.1.

262. Fink, supra note 31, at 5. 
countries, where many public goods are underprovided and enforcement challenges exist in many areas of law-fighting violence, guaranteeing real property rights, upholding contracts, stopping illegal logging of endangered forests, regulating traffic, and so on.”263

\section{B. Injunctions and Border Suspensions}

12.2. Each Party shall provide for injunctive relief consistent with Article 44 of the TRIPS Agreement, and shall also make injunctions available to prevent the exportation of infringing goods. ${ }^{264}$

14.4. Each Party shall provide that its competent authorities may initiate border measures ex officio with respect to imported, exported, or in-transit merchandise, or merchandise in free trade zones, that is suspected of being counterfeit or confusingly similar trademark goods, or pirated copyright goods. ${ }^{265}$

The TRIPS provisions on injunctions and border measures to restrain trade of intellectual property-infringing goods are limited. TRIPS obliges WTO members to grant injunctions only "to prevent the entry into the channels of commerce in their jurisdiction of imported goods that involve the infringement of an intellectual property right." 266 The border measures provisions of TRIPS require border officials to suspend only "the importation" of goods, and only in cases where there is prima facie evidence that the goods are "counterfeit trademark or pirated copyright goods."267

The limitation of the trade-injunction provisions in TRIPS is important for domestic sovereignty and free trade concerns. Because intellectual property laws are territorial, a good that violates the intellectual property law in one country may not violate the laws of another. Applying injunctions or border provisions to halt exports or in-transit shipments to countries where those goods may be lawfully received in effect allows one country to pass on

263. Id.

264. TPP IP I, supra note 21, art. 12.2.

265. Id. art. 14.4.

266. TRIPS Agreement, supra note 3, art. 44.1 (emphasis added).

267. Id. art. 51 . 
the domestic regulatory decisions of another. ${ }^{268}$ The restriction of border seizure mandates on suspected counterfeit and copyright piracy goods is similarly important because such goods "may generally be determined with certain ease, on the basis of the visual inspection of an imported good, since infringement will be apparent 'on its face." "’69

A significant hazard associated with expanding these standards was displayed in a large number of European seizures of generic medicines in transit beginning in 2008. As described by Henning Grosse Ruse-Kahn:

Starting in 2008, Dutch authorities decided to seize, delay, and return several shipments of generic drugs transiting E.U. ports en route to destinations in South America and Africa on account of suspected patent infringements. The shipments predominantly originated in India and were all destined for developing countries such as Brazil, Venezuela, Colombia, Peru, or Nigeria. The drugs at issue were protected in the E.U., but apparently not in the countries of origin or destination. Citing complaints of suspected infringement from alleged owners of patents or supplementary protection certificates, customs authorities in the Netherlands have detained a substantial amount of generic medicines in transit through the Netherlands. These consignments were initially detained and subsequently destroyed, returned to the country of origin, or, in a few cases, permitted to proceed to the destination country after considerable delay. ${ }^{270}$

A string of European seizures were implemented pursuant to a European Council regulation providing that customs authorities with "sufficient grounds for suspecting that goods infringe an intellectual property right,... may suspend the release of the goods" at the border. ${ }^{271}$ Dutch law interpreted this authority to include seizures of in-transit goods by adopting a "manufacturing fiction"-it assumed

268. See Frederick M. Abbott, Seizure of Generic Pharmaceuticals in Transit, 2009 WIPO J. 1, 44-46.

269. UNCTAD-ICTSD, supra note 43, at 610.

270. Henning Grosse Ruse-Khan, A Trade Agreement Creating Barriers to International Trade?: ACTA Border Measures and Goods in Transit, 26 AM. U. InT'L L. ReV. 645, 648 (2011) [hereinafter Ruse-Khan, Creating Barriers to International Trade].

271. European Communities Council Regulation No. 1383/2003, 2003 O.J. (L 196) 7 (EC). 
for purposes of application of Dutch patent law that transit of a good through the Netherlands would violate a patent if the manufacturing of the same good in Netherlands would violate the patent. ${ }^{272}$ The generic drugs in question were patented in the Netherlands, and therefore were considered to be in violation of the Netherlands patent law by virtue of their transit through the country, even though they were not subject to patents in their source or destination countries. Meanwhile, Germany seized a shipment of generic drugs based on suspicions that a generic medicine was using a name that was "confusingly similar" to a brand, although the name in fact was the International Nonproprietary Name ("INN") required to be used on any approved drug (including the brand) with the same active ingredient. ${ }^{273}$

The seizures were stoking considerable controversy and public attention at just the time that ACTA proposals on border measures were being leaked. ${ }^{274}$ Those leaks included proposals to

272. See Rb Den Haag 18 Juli 2008, No. KG ZA 08-617 m.nt. Kuipers (Sosecal/Sisvel) (Neth.) (upholding the manufacturing fiction); Abbott, Seizure of Generic Pharmaceuticals in Transit, supra note 268 at 37, 43 (discussing the Netherlands' and EU's decisions).

273. See e.g., Another Seizure of Generic Medicines Destined for a Developing Country, This Time in Frankfurt, THIRD WORLD NETWORK (June 5, 2009), http://www.haiweb.org/19062009/5 Jun\%202009\%20Press\%20release\%20Seizure \%20of\%20generic\%20medicines\%20in\%20Frankfurt.pdf (describing a seizure in Frankfurt, Germany, of the equivalent of approximately 76,000 courses of treatment worth of Amoxicillin bound for the Republic of Vanuatu, on the grounds of suspected trademark infringement).

274. See John W. Miller \& Geeta Anand, India Prepares EU Trade Complaint, Wall ST. J., Aug. 6, 2009; Frederick M. Abbott, Worst Fears Realised: The Dutch Confiscation of Medicines Bound from India to Brazil, 13 BRIDGES REV., no. 1, 2009 at 13; Kaitlin Mara, Generic Drug Delay Called 'Systemic' Problem at TRIPS Council, INTELL. PROP. WATCH (June 9, 2009), http://www.ipwatch.org/2009/06/09/generic-drug-delay-called-\%E2\%80\%9Csystemic\%E2\%80

\%9D-problem-at-trips-council; Pedro Fonseca \& Reese Ewing, Brazil to Object to Dutch Seizure of Generic Drug, ReUTERS, Jan. 23, 2009, http://www.reuters.com/ article/idUSN2327254420090123 (discussing Dutch seizure of a generic high blood pressure medicine bound for Brazil); Int'l Ctr. for Trade \& Sustainable Dev. [ICTSD], Dutch Seizure of Generic Drugs Sparks Controversy, 13 BRIDGES Wkly. Trade News Dig., no. 3, Jan. 28, 2009, at 5 (reporting on Brazil's criticism of seizures as a "distorted use of the international intellectual property system”); William New, Alarm Escalates Over Delayed Generic Drug Shipments as Action Sought, Intell. Prop. WATCH (Mar. 6, 2009, 5:13 PM), 
internationalize similar legal standards to those used in both the Dutch and German seizures. ${ }^{275}$ Later leaked drafts revealed proposals to expand injunction requirements to include prevention of the exportation of goods as well. ${ }^{276}$

The controversies around the Dutch seizures and the leaked drafts of ACTA had a notable impact on the negotiation. Later drafts of ACTA exempted patents from the Border Measures sections ${ }^{277}$ and made the application of the injunction provisions to patents optional. ${ }^{278}$ These changes were made as ACTA negotiators, particularly from the EU, were making public statements that "ACTA will not hinder the cross-border transit of legitimate generic medicines."279 ACTA remained controversial among access-tomedicine advocates ${ }^{280}$ and was rejected in the EU partially for this

http://www.ipwatch.org/weblog/2009/03/06/alarm-escalates-over-delayed-genericdrugshipments-as-action-sought/ (reporting on a statement from global health NGOs condemning Dutch seizures); Letter from NGOs to Pascal Lamy, Dir. Gen., WTO (Feb. 18, 2009), http://keionline.org/misc-docs/seizures/WTO_seizures_ 18feb.pdf; see also TRIPS Council, Intervention by India, Agenda Item ' $M$ ' Other Business - Public Health Dimension of TRIPS Agreement, at 2 (Feb. 4, 2009), available at http://ip-watch.org/weblog/wp-content/uploads/2009/03/ intervention-by-india.doc; TRIPS Council, Statement by Brazil, Agenda Item ' $M$ ' Other Business - Public Health Dimension of TRIPS Agreement, ๆף 15-16 (Feb. 4, 2009), available at http://ip-watch.org/weblog/wp-content/uploads/2009/03/ intervention-by-brazil.pdf (challenging Dutch seizures as violating TRIPS and WTO trade protections).

275. See James Love, Seven Secret ACTA Documents, KNOWLEDge ECOLOGY INT'L (Dec. 6, 2009), http://keionline.org/node/712; Ruse-Kahn, Creating Barriers to International Trade, supra note 270, at 665.

276. Anti-Counterfeiting Trade Agreement: Informal Predecisional/Deliberative Draft, Jan. 18, 2010, http://info.publicintelligence.net/actatreaty2010.pdf.

277. ACTA, supra note 18, art. 13 n.6. ("The Parties agree that patents and protection of undisclosed information do not fall within the scope of this section.”).

278. Id. art. 7 n.2. ("A Party may exclude patents and protection of undisclosed information from the scope of this Section.") (emphasis added).

279. Press Release, Eur. Comm'n, Anti-Counterfeiting Trade Agreement, Report on the 9th Round of Negotiations (July 2, 2010), http://trade.ec.europa.eu/ doclib/press/index.cfm?id=588\&serie=352\&langld=en.ACTA; see also Press Release, Eur. Comm'n, Anti-Counterfeiting Trade Agreement: European Commission Welcomes Release of Negotiation Documents (Apr. 21, 2010), http://trade.ec.europa.eu/doclib/press/index.cfm?id=552 (asserting that ACTA "will not hamper access to generic medicines").

280. See, e.g., Flynn \& Madhani, supra note 255; see also Press Release, Access Campaign, EU Parliament Rejects ACTA; Allowing for Continued Access to 
reason. $^{281}$

The TPP proposal reinstates a considerable amount of the most controversial scope of the ACTA proposals. The injunction provision explicitly extends to "exportation." And the border measures standards extend to exports as well as in transit shipments. Although the border measures provision does not extend to patents, its extension to confusingly similar trademark claims mirrors the standard used in the German seizure case. By definition, a confusingly similar mark is not identical to the infringing mark, and, therefore, it may not be possible to easily identify a violation through a visual comparison at the border. Courts in the United States, for example, apply numerous factors to determine whether consumers may be confused by the mark in question, under which the visual or other similarity of the mark is but a single, and often not determinative, factor. ${ }^{282}$ The inclusion of this standard as one that will be determined ex officio by border guards raises concerns that unjustified suspensions of trade among TPP member states will increase as a result.

The first part of TPP Article 12.2 proposes that TPP member states implement obligations regarding injunctions in TRIPS Article 44. This is different from ACTA's provision on the same subject where the affirmative duty to grant injunctions from TRIPS Article 44.1 is restated, but without restating or referencing the flexibilities

Generic Medicines in Developing Countries (July 4, 2012), available at http://www.msfaccess.org/about-us/media-room/press-releases/eu-parliament-

rejects-acta-allowing-continued-access-generic (reporting that the European Parliament voted to reject ACTA on the belief that ACTA as written "would have given an unfair advantage to patented medicines, and restricted access to affordable generic medicines to the detriment of patients and treatment providers alike") (internal quotations omitted).

281. See Magda Fahsi, Inside the European Parliament's Rejection of ACTA, MinTPRESS.NET (July 9, 2012, 2:21 PM), http://www.mintpress.net/inside-theeuropean-parliaments-rejection-of-acta/ (relying on Oxfam's explanation for a reason why the agreement was not popular in the European Parliament).

282. Barton Beebe, An Empirical Study of the Multifactor Test for Trademark Infringement, 94 CALIF. L. REV. 1581, 1582-83 (going through the various multifactor tests that each circuit has developed); see AMF, Inc. v Sleekcraft Boats, 599 F.2d 341 (9th Cir., 1979) (considering eight factors); see also In re E.I. du Pont de Nemours \& Co., 476 F.2d 1357 (C.C.P.A. 1973) (applying similar factors). 
recognized in TRIPS Article 44.2. ${ }^{283}$ TRIPS Article 44.2 is a key flexibility in TRIPS, providing that a country may always forgo the grant of injunctions whenever "these remedies are inconsistent with a Member's law," and as long as "declaratory judgments and adequate compensation shall be available." ${ }^{284}$ This provision enables countries to favor statutory licenses over injunctions in specific cases-a key flexibility in TRIPS that was called into question in ACTA.

\section{Damages}

12.3. Each Party shall provide that:

(a) in civil judicial proceedings, its judicial authorities shall have the authority to order the infringer to pay the right holder:

(i) damages adequate to compensate for the injury the right holder has suffered as a result of the infringement, and

(ii) at least in the case of copyright or related rights infringement and trademark counterfeiting, the profits of the infringer that are attributable to the infringement and that are not taken into account in computing the amount of the damages referred to in clause (i).

(b) in determining damages for infringement of intellectual property rights, its judicial authorities shall consider, inter alia, the value of

283. ACTA, supra note 18, art. 8.1 ("Each Party shall provide that, in civil judicial proceedings concerning the enforcement of intellectual property rights, its judicial authorities have the authority to issue an order against a party to desist from an infringement, and inter alia, an order to that party or, where appropriate, to a third party over whom the relevant judicial authority exercises jurisdiction, to prevent goods that involve the infringement of an intellectual property right from entering into the channels of commerce.”).

284. TRIPS Agreement, supra note 3, art. 44.2 ("Notwithstanding the other provisions of this Part and provided that the provisions of Part II specifically addressing use by governments, or by third parties authorized by a government, without the authorization of the right holder are complied with, Members may limit the remedies available against such use to payment of remuneration in accordance with subparagraph (h) of Article 31. In other cases, the remedies under this Part shall apply or, where these remedies are inconsistent with a Member's law, declaratory judgments and adequate compensation shall be available.”). 
the infringed good or value submitted by the right holder. ${ }^{285}$

12.4. In civil judicial proceedings, each Party shall, at least with respect to works, phonograms, and performances protected by copyright or related rights, and in cases of trademark counterfeiting, establish or maintain a system that provides for pre-established damages, which shall be available upon the election of the right holder. Pre-established damages shall be in an amount sufficiently high to constitute a deterrent to future infringements and to compensate fully the right holder for the harm caused by the infringement. In civil judicial proceedings concerning patent infringement, each Party shall provide that its judicial authorities shall have the authority to increase damages to an amount that is up to three times the amount of the injury found or assessed. ${ }^{286}$

The U.S. TPP proposal includes a series of requirements that determinations of damages in infringement cases exceed a compensatory level, including statutory damages "sufficiently high to constitute a deterrent to future infringement." These standards are far beyond the parallel provisions of TRIPS, which require the authority to award only "damages adequate to compensate for the injury the right holder has suffered," and only in cases of infringement by a person "who knowingly, or with reasonable grounds to know, engaged in infringing activity."287

A key problem with these compensation-plus measures is that they ignore the phenomenon of exclusionary pricing, particularly in developing countries. The economic evidence suggests that it will often be profit maximizing for an intellectual property holder to charge roughly the same price in poor countries with high income

285. TPP IP I, supra note 21, art. 12.3.

286. Id. art. 12.4 .

287. TRIPS Agreement, supra note 3, art. 45(1). ACTA's provision on damages also applies only to "the infringer who, knowingly or with reasonable grounds to know, engaged in infringing activity." ACTA supra note 18, art. 9.1 (requiring "damages adequate to compensate for the injury the right holder has suffered as a result of the infringement ... which may include lost profits"). TRIPS permits, but does not require, the availability of disgorgement of profits or statutory damages. TRIPS Agreement, supra note 3, art. 44(2) ("Members may authorize the judicial authorities to order recovery of profits and/or payment of pre-established damages even where the infringer did not knowingly, or with reasonable grounds to know, engage in infringing activity.”). 
inequality as in wealthy countries with less inequality. ${ }^{288}$ We thus see pricing of media goods in poor countries as luxury goodsaffordable only to a sliver of the population. ${ }^{289}$ Awarding damages for mass-market piracy that serves unmet demand based on the retail price of the excessively priced good overcompensates the rights holder, thus reinforcing the exclusionary pricing behavior that created the market for the pirate goods in the first instance.

The imposition of pre-established, or "statutory," damages compounds the problem of unrealistic damage awards by removing any need to prove harm at all. Such damages are not recognized in every major copyright system, and there are increasing criticisms of the statutory damages in current U.S. law. ${ }^{290}$ In ACTA, pre-established damages were not required. Parties were given the choice between preestablished damages, presumptions for determining the amount of damages, or "additional" copyright damages. ${ }^{291}$ U.S. law provides for statutory damages for copyright violations but does not require that such damages be sufficiently high to constitute a deterrent to future infringements. ${ }^{292}$ Normally, civil damages for violation of private rights, including rights to contract and property, are to compensate, not deter.

The proposed triple damages scheme for patent violations is extreme. U.S. law reserves treble damages for willful patent

288. See Flynn et al., supra note 32 (describing the economics of pricing in countries with high income inequality); MEDIA PIRACY IN EMERGING ECONOMIES, supra note 32, at 55-57 (reporting prices of \$20.50 and \$8.50 in South Africa and India, respectively, for the same Coldplay album sold in the United States for $\$ 17$, and reporting GDP per capita in the three countries, respectively, as $\$ 5,824$, $\$ 1,031$, and \$46,857).

289. See Media Piracy in Emerging Economies, supra note 32, at 10 (summarizing the most recent industry-cited rates of piracy, including $90 \%$ of the film market and $81 \%$ of the game market in India); id. at 57-61 (reporting on pirate market prices, and suggesting that prices for pirated DVDs in excess of \$1 per film "reflects a constraint on trade").

290. See Pamela Samuelson \& Tara Wheatland, Statutory Damages in Copy Right Law: A Remedy in Need of Reform, 51 WM. \& MARY L. REV. 439, 441 (2009) (" $[\mathrm{T}]$ he United States is an outlier in the global copyright community in giving plaintiffs in copyright cases the ability to elect, at any time before final judgment.”).

291. ACTA, supra note 18, art. 9.3.

292. See Griffin, supra note 88 (explaining section 504(c) of the U.S. Copyright Act). 
infringement. ${ }^{293}$ However, TPP's standard does not confine its requirement to such cases, and even that standard would not be appropriate for all countries. Medicines, like music, are subject to uniform global pricing. The $\$ 10,000$ price in poor countries for AIDS medications in 1999 that are now on the market for less than \$100 was rational, and many medicines are similarly priced at uniform levels in rich and poor countries today. ${ }^{294}$ What should be the damage measure for a generic competitor introducing the $\$ 100$ copy of the $\$ 10,000$ drug found to infringe on a patent claim of the originator? The TPP proposal suggests $\$ 9,900$ per infringing copy, tripled, plus litigation costs. Such a standard would severely deter generic competition with brand holders - a result that is likely intended and would be severely detrimental to access-to-affordable-medicine concerns.

\section{Criminal Offenses: "Commercial Scale”}

15.1 Each Party shall provide for criminal procedures and penalties to be applied at least in cases of willful trademark counterfeiting or copyright or related rights piracy on a commercial scale. Willful copyright or related rights piracy on a commercial scale includes:

(a) significant willful copyright or related rights infringements that have no direct or indirect motivation of financial gain and

(b) willful infringements for purposes of commercial advantage or private financial gain.

For greater certainty, “financial gain” for purposes of this Article includes the receipt or expectation of anything of value. ${ }^{295}$

The U.S. proposal on criminal offenses appears to require that nearly every copyright violation be treated as a crime, and in so doing would implement a position it lost in a recent WTO dispute with China. ${ }^{296}$

293. See 35 U.S.C. § 284.

294. See generally Flynn et al., supra note 32.

295. TPP IP I, supra note 21, art. 15.1, n.24 (footnote number omitted).

296. Panel Report, China - Measures Affecting the Protection and Enforcement

of Intellectual Property Rights, WT/DS362/R, 107-116 (Jan. 26, 2009)

[hereinafter WTO, China-Measures]. 
The U.S.-China case in the WTO arose from the TRIPS Article 61 requirement that member states criminalize cases of willful trademark counterfeiting or copyright piracy “on a commercial scale.”297 China implemented its mandate by making such acts criminal only where they met certain thresholds for the quantity of infringing goods produced. The United States challenged China's statutory thresholds as being so high as to exclude some activity with a commercial purpose that did not reach the quantitative thresholds. The WTO panel rejected this definition as reading out the "scale" requirement in Article 61, holding that countries are free to limit criminal penalties to infringement "carried on at the magnitude or extent of typical or usual commercial activity with respect to a given product in a given market." 298

297. TRIPS Agreement, supra note 3, art. 61; see UNCTAD-ICTSD, supra note 43, at 620-21 (discussing flexibilities in Article 61, which accommodate "very different approaches with regard to the application of criminal penalties in cases of IPR infringement"); Christophe Geiger, The Anti-Counterfeiting Trade Agreement and Criminal Enforcement of Intellectual Property: What Consequences for the European Union?, Max PlancK INST. FOR INTELL. PRop. \& COMPETITION LAW (Max Planck Inst. for Intell. Prop. \& Competition Law Research Paper Series No. 12-04, 2012), at 4, available at http://papers.ssrn.com/sol3/papers.cfm?abstract_ id=2038272 ("It is clear from the negotiations history that Member States were meant, in consistency with Art. 1.1 of the Agreement, to have considerable flexibility when deciding the manner to implement these criminal penalties in their national law.").

298. WTO, China - Measures, supra note 296, ๆ 7.577; see also id., ๆๆ 7.551-52 (criticizing a U.S. interpretation that "interprets 'commercial scale' as basically everything that is 'commercial' with the exception of some trivial or de minimis activities," and noting that the "difference is minimal" between such a definition and one that equates "commercial scale" with "an identical class of acts as the term 'commercial purpose””); id. at 97.576 (“[E]ach of the words 'commercial' and 'scale' provides important context for the interpretation of the other .... [I]t is clear that none of these uses refer to activities that are simply commercial. Rather, they are evidently intended to distinguish certain activities (or premises) from others that pertain to or have a bearing on commerce but which do not meet a market benchmark in terms of what is typical."). For analysis of the decision, see generally Daniel Gervais, China-Measures Affecting the Protection and Enforcement of Intellectual Property Rights, 103 AM. J. INT’L L. 549, 552-53 (2009) (outlining the qualitative and the quantitative thresholds used to decide whether an activity is on a commercial scale); H. Grosse Ruse-Khan, Criminal Enforcement and International Law in CRiminal ENFORCEMENT OF INTELLECTUAL ProperTy (C. Geiger ed., 2011); Peter K. Yu, Shaping Chinese Criminal Enforcement Norms Through the TRIPS Agreement, in Criminal Enforcement of Intellectual Property (C. Geiger 
The U.S. TPP proposal would put in place the position it lost in the WTO. It separates the quantitative and qualitative assessments and requires countries to criminalize all willful copyright "infringement" intended to receive "anything of value," regardless of scale. ${ }^{299}$ This is an incredibly broad definition that would appear to criminalize every "willful” infringing act of copying, which, by definition, gives something of value to its receiver. ${ }^{300}$

The proposal lacks tempering standards in U.S. law. The language in the proposal is based loosely on section 506 of the U.S. Copyright Act, through which criminal liability attaches to willful infringement of copyright "for purposes of commercial advantage or private financial gain." 301 But the U.S. Department of Justice has taken the position that Congress's purpose is "to exclude from criminal liability those individuals who willfully infringe copyrights solely for their own personal use.”302 The U.S. proposal does not reflect this qualification. Nor does it reflect the

ed., 2011); Peter K. Yu, The U.S.-China Dispute over TRIPS Enforcement Drake University Law School, Occasional Papers in Intellectual Property Law No. 5 (2010), http://www.law.drake.edu/academics/ip/docs/ipResearch-op5.pdf; Peter K. Yu, The TRIPS Enforcement Dispute, 89 NEB. L. REV. 1046, 1066-67 (2011); Peter K. Yu, TRIPS Enforcement and Developing Countries, 26 AM. U. INT'L L. REV. 727 (2011).

299. Id. art. 15.1(b). In this sense, the U.S. TPP proposal is similar to the U.S. proposal for a criminal provision in ACTA, which was ultimately rejected in the final text of that agreement. Cf. Ruse-Khan, Gold Standard, supra note 25, at 15 (describing leaked drafts of a proposed criminal chapter and contrasting them with the final text); ACTA, supra note 18, art. 23.1 ("For the purposes of this Section, acts carried out on a commercial scale include at least those carried out as commercial activities for direct or indirect economic or commercial advantage.”).

300. See Ruse-Khan, Gold Standard, supra note 25, at 16 ("The notion of 'indirect economic or commercial advantage' might cover internet users downloading copyrighted files without right holder authorization and so receiving an (indirect) economic advantage of not having to pay the retail price.”).

301. 17 U.S.C. $\S 506(a)$ (2011).

302. 1851 Copyright Infringement-Fourth Element-Commercial Advantage or Private Financial Gain, DEP'T OF JUSTICE, http://www.justice.gov/usao/eousa/ foia_reading_room/usam/title9/crm01851.htm (last visited Sept. 9, 2012) (citing H.R. Rep. No. 997, 102 Cong., 2d Sess. 5 (1992)) (suggesting the example of "bartering (i.e., the practice of exchanging infringing works for other infringing works)," rather than the mere receipt of goods of value, as an example where the standard could be triggered without money changing hands). 
quantitative definition of "significant" as limiting criminal infringement to cases where at least $\$ 1,000$ worth of material is reproduced in a 180-day period. ${ }^{303}$

The TPP provision would shift more burden for bringing enforcement actions from private right holders to the public. Normally the responsibility for enforcing IP infringements and other private rights lies with the right holder through private court actions. By making the infringement criminal, the responsibility and cost of enforcement shifts to the public. By criminalizing essentially all willful copyright infringement, the TPP proposed standard fails to target the most socially harmful conduct. ${ }^{304}$ The shift of the enforcement power to the government may also invite abusive procedures in some countries, including the use of copyright enforcement as a pretext for official censorship. ${ }^{305}$

Over-criminalizing copyright infringement may have negative effects. The fear of over-enforcement may dissuade the use of copyrighted materials in new business models, in new expressive works, or for socially beneficial activities, such as teaching. Overcriminalization may also implicate fundamental rights concerns.

303. See Griffin, supra note 88 , at 8.

304. See Geiger, The Anti-Counterfeiting Trade Agreement and Criminal Enforcement of Intellectual Property, supra note 297, at 11 (arguing that the escalation of remedies from civil law to criminal law should be motivated by "the aggravated social harm of the infringement”); Reto Hilty et al., Competition and Tax Law on the Proposal for a Directive of the European Parliament and of the Council on Criminal Measures Aimed at Ensuring the Enforcement of Intellectual Property Rights 6 (2006), available at http://www.ip.mpg.de/files/pdf2/CommentsEnforcementOfIP-Rights.pdf (making a proposal to limit criminalization "to acts that are particularly dangerous from the viewpoint of public interest," such as infringements that carry health or safety risk). A clear-eyed economic appraisal needs to admit that infringing activities can have social benefits as well as costs. Fink, supra note 31, at 7. ("Governments face a trade-off in formulating intellectual property policies: stronger exclusive rights increase incentives for information and knowledge-producing investments, but also increase the economic efficiency loss due to market structure deviating from its competitive ideal.”); Media Piracy in Emerging Economies, supra note 32, ch. 1 (describing economic benefits to developing countries that derive from replacing high-priced imports with locally produced pirated media products).

305. See Clifford J. Levy, Russia Uses Microsoft to Suppress Dissent, N.Y. TIMES, Sept. 12, 2010, at A1 (reporting on the confiscation of computers in Irkutsk, Russia, "under the pretext of searching for pirated Microsoft software"). 
International human rights doctrines and many regional or national human rights instruments require that penalties be proportionate to the crime. Using the criminal law to deal with more common forms of infringement may be disproportionate under such clauses, ${ }^{306}$ and may also violate "the right to freedom to obtain and disseminate information, the right to freedom from unreasonable search and arrest, the right to inviolability of the home, and the right to the peaceful enjoyment of one's possessions." 307

\section{E. Internet Service Provider Liability}

Art. 16.3. For the purpose of providing enforcement procedures that permit effective action against any act of copyright infringement covered by this Chapter, including expeditious remedies to prevent infringements and criminal and civil remedies that constitute a deterrent to further infringements, each Party shall provide, consistent with the framework set out in this Article:

(a) legal incentives for service providers to cooperate with copyright owners in deterring the unauthorized storage and transmission of copyrighted materials; and

(b) limitations in its law regarding the scope of remedies available against service providers for copyright infringements that they do not control, initiate or direct, and that take place through systems or networks controlled or operated by them or on their behalf, as set forth in this subparagraph (b). ${ }^{308}$

Art. 15.4. With respect to the offenses for which this Article requires the Parties to provide for criminal procedures and penalties, Parties shall

306. DOUWE KorfF \& IAN BROWN, Opinion ON THE COMPATIBILITY OF THE ANTI-COUNTERFEITING TRADE AgrEemENT (ACTA) WITH THE EuropeAN CONVENTION ON HUMAN Rights \& THE EU CHARTER OF FUNDAMENTAL RightS 47 (2010), available at http://www.greens-efa.eu/fileadmin/dam/Documents/ Studies/ACTA_fundamental_rights_assessment.pdf.

307. Id.; see Jonathan Griffiths, Criminal Liability for Intellectual Property Infringement in Europe - The Role of Fundamental Rights, in CRIMINAL Enforcement of InTEllectual Property: A Blessing OR A CuRse (C. Geiger ed., 2011) 1, 4, 9-11 (arguing that every person is entitled to personal privacy, freedom of expression, and the enjoyment of his or her home and possessions, and that penalties must not be so severe as to be disproportionate with the nature of the criminal offense).

308. TPP IP I, supra note 21, art. 16.3. 
ensure that criminal liability for aiding and abetting is available under its law.

TPP contains three sets of standards that encourage Internet service providers ("ISPs") to police the content of users of their networks.

First, TPP Article 16.3(a) requires parties to provide "legal incentives for service providers to cooperate with copyright owners in deterring the unauthorized storage and transmission of copyrighted materials.”309 ACTA requires only that governments "endeavor to promote cooperative efforts within the business community." 310 Providing legal incentives for ISPs to police the Internet is a complex task, for which negotiation of standards in secretive international processes is completely inappropriate. Intermediaries' interests are not perfectly aligned with user interests. Legal incentives for intermediaries to police networks may lead to the censoring of content, including legitimate content, choking innovative technology built on their platforms; surveillance of users; and threats to privacy and freedom of expression. ${ }^{311}$ The kind of private ordering of copyright enforcement represented by the TPP text has been a method of choice in the United States, as evidenced by a recent Memorandum of Understanding between intermediaries and content owners, encouraged by the U.S. Copyright Czar. ${ }^{312}$ Language about encouraging such cooperation

309. Id. art. 16.3(a).

310. ACTA, supra note 18, art. 27.3.

311. See Margot Kaminski, Plurilateral Trade Agreements Lack Protections for Users, Intermediaries, InTELl. Prop. WATch (Oct. 27, 2011, 11:47 PM), http://www.ip-watch.org/2011/10/27/plurilateral-trade-agreements-lackprotections-for-users-intermediaries/ [hereinafter Kaminski, Plurilateral Trade Agreements].

312. See David Kravets, U.S. Copyright Czar Cozied Up to Content Industry, E-Mails Show, WIRED.COM (Oct. 14, 2011, 6:30 AM), http://www.wired.com/ threatlevel/2011/10/copyright-czar-cozies-up/\#more-31071 (reporting on the personal email records of U.S. Copyright Czar Victoria Espinel, indicating that the government required "internet service providers, for the first time, to punish residential internet-service customers who media companies suspect are violating copyright rules by downloading copyrighted movies or music from peer-to-peer networks"). See generally Annemarie Bridy, Graduated Response and the Turn to Private Ordering in Online Copyright Enforcement, 89 OR. L. REv. 81 (2010) (analyzing private ordering copyright enforcement and graduated response). 
should be viewed in light of these developments, which leave businesses unaccountable to users, and users without normal expectations of due process protected through court proceedings.

Second, the TPP proposal introduces a series of liability safeguards for ISPs and, in so doing, may promote the extension of secondary liability to ISPs. Intermediary liability is not universally recognized. USTR has recognized that creating limitations on liability encourages countries to adopt intermediary liability in the first instance. ${ }^{313}$

It can be argued that TPP Article 16.3 mandates a system of ISP liability that goes beyond DMCA standards and U.S. case law. ${ }^{314}$ For example, TPP Article 16.3(b)(xi) requires ISPs to identify Internet users suspected of infringement, where U.S. courts have found that ISPs are not subject to identification subpoenas. ${ }^{315}$ TPP Article 16.3(b)(xi) lacks ACTA Article 27.4's requirements that (i) there be a sufficient claim of infringement, (ii) the information be sought for the purpose of protecting or enforcing a copyright, and (iii) the procedures shall be implemented in a manner that avoids the creation of barriers to legitimate activity. TPP Article 16.3(b)(vii) also fails to include the DMCA's second privacy provision, that intermediaries may not access material contrary to law. ${ }^{316}$ ACTA Article 27.2 similarly requires that any system of digital enforcement be consistent with that Party's law and preserve fundamental principles such as freedom of expression, fair process, and privacy. There are other examples of discrepancies between the TPP and DMCA, as well. ${ }^{317}$

Finally, TPP contains language in Article 15.4 criminalizing "aiding and abetting” copyright infringement that is likely intended to apply to online intermediaries. The provision on aiding and abetting in ACTA Article 23.4 was directly followed by a provision requiring liability for legal persons - that is, companies. Criminal aiding and abetting has not appeared in other free trade agreements and, when read in light of

313. See, e.g., United States-Peru Trade Promotion Agreement, supra note 176, ch. 29 n. 28.

314. TPP IP I, supra note 21, art. 16.3.

315. Id. art. 16.3(b)(xi).

316. Digital Millennium Copyright Act, 17 U.S.C. § 512(m)(2) (2010).

317. See generally Kaminski, Plurilateral Trade Agreements, supra note 311. 
ACTA's language on legal persons, may very well be intended to apply to intermediaries. In the United States, the Bureau of Immigrations and Customs Enforcement has been seizing domain names, based in part on this theory of criminal liability. ${ }^{318}$ Criminal liability for intermediaries could threaten even those intermediaries that comply with safe harbors, as criminal and civil systems are distinct.

\section{CONCLUSION}

The future of the U.S. TPP proposal for an intellectual property chapter, and its broader plurilateral agenda, is very much in doubt. The dynamics of the TPP do not favor the kind of maximalist IP chapter the United States has proposed. The barriers facing its ultimate expansion to countries the United States is more concerned about - to China, Brazil, and India, for example - are even more pronounced. The problems for the United States can be described in terms of balance, inclusion, and democratic process.

This paper has primarily concentrated on the problems of lack of substantive balance in the U.S. proposal, which is thwarting its acceptance by negotiating parties. The proposal shows that U.S. negotiators are trying to convince the poorest countries of the worldthe likes of Vietnam and Peru, for example-to adopt the same or higher intellectual property protection and enforcement mandates that exist in the United States or that have been achieved in agreements with the highest income countries (e.g., in the U.S.-Korea FTA). The proposal displays that the United States continues to selectively export U.S. law, focusing on the exportation of protections and not exceptions. Succeeding in this agenda in the TPP will be exceedingly difficult. Countries that have accepted such standards in past trade agreements with the United States did so as a tradeoff for U.S. market access. But most of the TPP member states already have U.S. FTAs giving them market access. The U.S. negotiators must persuade many of the

318. See David G. Robinson, Following the Money: A Better Way Forward on the Protect IP Act 9 (Yale Law School Info. Soc'y Project, 2011), available at http://www.law.yale.edu/intellectuallife/6564.htm ("[S]ites whose domain names are seized are often one step distant from the actual infringers - one study found that ' $[\mathrm{t}] \mathrm{he}$ underlying claim in most of the cases in Operation In Our Sites is the website violated copyright law by linking to other web sites that stored infringing content.”). 
countries to accept the intellectual property commitments in exchange for nothing. This dynamic emboldens the non-U.S. countries to stand firmer in their convictions and will likely result in an intellectual property chapter that looks very different from the U.S. proposal.

The lack of inclusion of a broader group of member states in the negotiation process will pose barriers for the ultimate U.S. and broader TPP ambition of expanding the agreement to other countries. In multilateral negotiations like in the WTO or WIPO, where the forum is technically open to all countries of the world that care to join, the real work of negotiating the applicable text is done by a smaller number of countries representing various coalitions. The U.S. pursuit of geographically diverse plurilateral agreements for later expansion can be seen as a reflection of this reality, and in the abstract its effort to create such agreements is not assailable. The important question, however, is who is at the table. If the plurilateral coalition intends to expand, then it should include the most influential and affected members of the expanded field at the table from the onset. The problem, as Peter Yu has remarked, is not that the TPP (he was speaking of ACTA) is a "country club" agreement, but rather it is a bad country club agreement because the initial club setting the rules is not adequately representative of the rest. ${ }^{319}$

Finally, there is the issue of democratic process. The TPP process was established in 2008, at a time when ACTA seemed to be humming along smoothly. Negotiators may have surmised that secrecy works. But after ACTA's implosion, a more rational conclusion would be that secrecy is counter-productive. It increases rather than decreases controversy so that whatever final text arrives from the process will be received by the public and their representatives with derision. The process thus far has not responded to this lesson; there have been no meaningful increases in the transparency or public participation opportunities in the TPP since ACTA's demise. If TPP as well suffers a spectacular failure because of a public rejection of its process, then the larger U.S. agenda of shifting these broad and important lawmaking initiatives into secret forums may be disrupted. That, in turn, may stoke a reconsideration of the processes required for international intellectual property lawmaking to be considered legitimate in the face of their

319. Peter Yu, ACTA and Its Complex Politics, 2011 WIPO J. 1, 5. 
broad impacts in the public at large. ${ }^{320}$

320. See, e.g., Washington Declaration, supra note 22 (calling for all international intellectual property negotiations to be "conducted through mechanisms of transparency and openness that encourage broad public participation," "within the existing forums responsible for intellectual property policy, where both developed and developing countries have full representation, and where the texts of and forums for considering proposals are open”). 